This article is (C) Emerald Group Publishing and permission has been granted for this version to appear here

(http://strathprints.strath.ac.uk/50435/). Emerald does not grant permission for this article to be further copied/distributed or hosted elsewhere without the express permission from Emerald Group Publishing Limited.

\title{
HOW MANY CALORIES? FOOD AVAILABILITY IN ENGLAND AND WALES IN THE $18^{\mathrm{TH}}$ AND $19^{\mathrm{TH}}$ CENTURIES*
}

Bernard Harris, ${ }^{\dagger}$ Roderick Floud ${ }^{\ddagger}$ and Sok Chul Hong.**

\section{ABSTRACT}

In The Changing Body (Cambridge University Press and NBER, 2011 ), we presented a series of estimates showing the number of calories available for human consumption in England and Wales at various points in time between 1700 and 1909/13. We now seek to correct an error in our original figures and to compare the corrected figures with those published by a range of other authors. We also include new estimates showing the calorific value of meat and grains imported from Ireland. Disagreements with other authors reflect differences over a number of issues, including the amount of land under cultivation, the extraction and wastage rates for cereals and pulses and the number of animals supplying meat and dairy products. We consider recent attempts to achieve a compromise between these estimates and challenge claims that there was a dramatic reduction in either food availability or the average height of birth cohorts in the late-eighteenth century.

JEL No. N01, N33, N53, O1, O13, O52.

An earlier version of this paper was published as an NBER Working Paper (Working Paper 20177). Earlier versions were also presented at conferences on 'Global inequality and poverty since 1800: evidence, analysis and data sources', held at the University of Sussex on 27-28 September 2013; and 'The Health Transition: A Conference in Memory of Robert Fogel', held at the University of Chicago on 4 October 2013. We would also like to thank Stanley Engerman, David Meredith, Cormac Ó Gráda and Deborah Oxley for their helpful comments on previous versions, and Steve Broadberry for permission to cite unpublished work from his forthcoming co-authored book (Broadberry et al. forthcoming).

$+\quad$ School of Social Work and Social Policy, Lord Hope Building, University of Strathclyde, 141 St James Road, Glasgow G4 0LT. Email: bernard.harris@strath.ac.uk

* NBER and 15 Flint Street, Haddenham, Bucks HP17 8AL. Email: roderick.floud@btinternet.com.

** Department of Economics, Sogang University, 35 Baekbeom-ro, Mapo-gu, Seoul, Korea 121-742. Email: shong@sogang.ac.kr. 
This article is (c) Emerald Group Publishing and permission has been granted for this version to appear here

(http://strathprints.strath.ac.uk/50435/). Emerald does not grant permission for this article to be further copied/distributed or hosted elsewhere without the express permission from Emerald Group Publishing Limited.

Recent years have witnessed the publication of several efforts to estimate the number of calories available for human consumption in Britain from the thirteenth century onwards. Although these papers have often drawn on similar sources, they have sometimes reached divergent conclusions about both levels and trends. These disagreements have profound implications for our understanding of a range of issues, including the measurement of basic living standards, the relationship between diet and health, and the impact of food availability on economic growth, both in the British Isles and more widely.

We now seek to contribute to these debates in a number of different ways. We begin by correcting an arithmetical error in Floud et al.'s original findings and offering a more detailed summary of several of the major publications in the field. The second section compares Floud et al.'s corrected estimates with the results of recent work by Stephen Broadberry and his coauthors. The third section introduces a significant amount of new data on the number of calories obtained from food imported into Britain from Ireland. The final section highlights some of the problems associated with recent authors' attempts to construct a composite series and relates this discussion to the analysis of trends in real wages, height and mortality in Britain.

We pay particular attention to two sets of issues. In the first place, we revisit the controversial question of how to make appropriate allowances for the conversion of cereal crops into edible human food, and recalculate Floud et al.'s corrected estimates using the extraction rates which were first discussed by Overton and Campbell in 1996. We also introduce a substantial amount of new information about the calorific value of Irish imports. We suggest that these items may have contributed almost 90 additional calories per person per day in 1800 and more than 150 additional calories in 1850 . 
This article is (c) Emerald Group Publishing and permission has been granted for this version to appear here

(http://strathprints.strath.ac.uk/50435/). Emerald does not grant permission for this article to be further copied/distributed or hosted elsewhere without the express permission from Emerald Group Publishing Limited.

In their original study, Floud, Fogel, Harris and Hong (2011, pp. 155-7, 205-9)

presented two different sets of estimates, based on the use of different sources to estimate levels of agricultural productivity. The first set of figures (Estimate A) suggested that the total number of calories fell between 1700 and 1750 but rose during each of the next two half-centuries. Estimate B suggested that there was a very small increase in food availability during the first half of the eighteenth century, followed by further increases between 1750 and 1800 and between 1800 and 1850 . However, the contrast between the revised estimates is somewhat greater. The revised version of Estimate $A$ suggests that calorie availability increased between 1700 and 1750 and between 1750 and 1800, with little change between 1800 and 1850. The revised version of Estimate B suggests that there was a much larger increase in food availability during the first half of the eighteenth century, followed by a small decline and then an increase.

A key issue in these debates concerns the representativeness of the sources on which the two sets of estimates are based. The figures showing the total number of calories derived from domestically-produced cereals and pulses in Estimate A were derived from Holderness' (1989) assessment of a range of returns compiled by contemporary investigators in the eighteenth and nineteenth centuries. The equivalent figures in Estimate B were based on Turner, Beckett and Afton's (2001) reconstruction of contemporary estate inventories. These authors provided a much more detailed account of the methods used to derive their figures but the number of records was relatively small and they were drawn from counties which may not have been entirely representative of the country as a whole (Thirsk, 2002).

These revised estimates have significant implications for our understanding of the precise relationship between the chronology of changes in food availability and changes in health and mortality. In their original study, Floud et al. (2011, pp. 162- 
This article is (c) Emerald Group Publishing and permission has been granted for this version to appear here

(http://strathprints.strath.ac.uk/50435/). Emerald does not grant permission for this article to be further copied/distributed or hosted elsewhere without the express permission from Emerald Group Publishing Limited.

3) argued that changes in food availability were 'broadly consistent' with changes in

height and life expectancy during the late-eighteenth and early-nineteenth centuries and this supported the view that improvements in food availability were one cause of improvements in height and mortality during this period. Although this statement is still true of the revised version of Estimate $A$, it is less true of the revised version of Estimate $B$. The difference between the two estimates therefore helps to reinforce Joyce Burnette's (2014, p. 115) recent call for new research into the changing level of agricultural productivity before 1870 .

The revised figures also have significant implications for Floud et al.'s arguments about the extent to which the total amount of food available was sufficient to meet nutritional needs. After taking account of the nutritional needs of an adult male engaged in 'heavy work', they argued that the amount of food available was insufficient to meet the needs of the whole population before circa 1850. The revised versions of both Estimates suggest that the amount of food may have started to exceed this threshold at a somewhat earlier date even though a substantial proportion of the population was likely to have remained at risk of nutritional inadequacy for much of the nineteenth century (see also Gazeley and Newell, 2014).

Although the new estimates are significantly higher than Floud et al.'s original figures, they are still much lower than the estimates produced by Allen (2005) and Muldrew (2011). We offer a detailed discussion of the methods which Allen used to estimate the number of calories derived from potatoes but pay particular attention to Muldrew's figures. We argue that these figures rest on very generous assumptions about the amount of land devoted to cereal cultivation, the proportion of the total cereal crop which became available for human consumption, and the number of animals producing milk, butter and cheese. 
This article is (c) Emerald Group Publishing and permission has been granted for this version to appear here

(http://strathprints.strath.ac.uk/50435/). Emerald does not grant permission for this article to be further copied/distributed or hosted elsewhere without the express permission from Emerald Group Publishing Limited.

We also compare our revised estimates with the composite series presented by

Kelly and Ó Gráda (2013a; $2013 b)$ and, more especially, Meredith and Oxley (2014). Meredith and Oxley applied the figures which Floud et al. used to calculate the proportion of domestically-produced cereals entering gross product to Muldrew's data on land use and productivity, and then added them to Floud et al.'s own data on food imports to produce a revised set of eighteenth-century calorie estimates. They then extended the resulting series by combining it with Floud et al.'s original estimates for 1850 and 1909/13. They also compared their new series with Gregory Clark's (2007) price data and with a number of different sets of anthropometric data. The majority of these series were derived from convict data but they also presented a new set of military height estimates, based on their own recalculation of Floud, Wachter and Gregory's (1990) estimates.

Although Meredith and Oxley's paper represents an important contribution to the study of historical patterns of food availability, we argue that this exercise was flawed because it failed to take account of the excessive nature of the figures which Muldrew used to estimate land use and the number of dairy animals. Although the available data remain problematic, we argue that there is little evidence to support the view that there was a substantial decline in food availability before the end of the eighteenth century and, as we have seen, the revised version of Floud et al.'s Estimate A suggests that there was actually a significant increase. We also question the principles which Meredith and Oxley followed when they attempted to recalculate Floud, Wachter and Gregory's height series. Although this topic remains controversial, the available evidence continues to suggest that there were significant improvements in both height and life expectancy before circa 1820 . 
This article is (c) Emerald Group Publishing and permission has been granted for this version to appear here

(http://strathprints.strath.ac.uk/50435/). Emerald does not grant permission for this article to be further copied/distributed or hosted elsewhere without the express permission from Emerald Group Publishing Limited.

\section{Estimating food availability}

During the 1980s and 1990s, a number of authors attempted to reconstruct the dietary history of the British population using evidence from the household budgets collected by contemporary investigators such as David Davies (1795), Frederick Morton Eden (1797), William Neild (1842), Edward Smith (Parliamentary Papers, $1863 ; 1864$ ) and others (see Oddy, 1990, p. 269). However, these reconstructions were marred by disagreements over the selection of relevant budgets and the representativeness of the populations from which they were drawn (Harris 2004, pp. 386-7; Floud et al. 2011, pp. 152-4). This helped to fuel a growing interest in the use of agricultural accounts to estimate the total amount of food which was produced in Britain at different points in time.

One of the earliest attempts to estimate food availability from these sources was made by Mark Overton and Bruce Campbell in a paper which was originally published (in French) in Histoire et Mésure in 1996 (Overton and Campbell, 1996). An English-language version was presented to a session at the World Economic History Congress in Helsinki ten years later (Overton and Campbell, 2006). The authors estimated the total number of calories provided by a number of different cereal crops and by potatoes for a series of years between 1300 and 1871. Based on these figures, they estimated that the total number of calories provided by these crops fell from a possible peak of around 1669 calories per head per day in 1380 to 1060 calories per head per day 491 years later. However, when these figures were added to the number of calories supplied by imported foods, the total number of calories from potatoes and grains in 1871 rose from 1060 to 1796 (Overton and Campbell, 1996, p. 296; 2006, p. 45).

Overton and Campbell's original paper has not always received the attention it deserved. It was overlooked by Fogel (2004) and by Floud et al. (2011), and was 
This article is (c) Emerald Group Publishing and permission has been granted for this version to appear here

(http://strathprints.strath.ac.uk/50435/). Emerald does not grant permission for this article to be further copied/distributed or hosted elsewhere without the express permission from Emerald Group Publishing Limited.

also omitted from the Bibliography of Robert Allen's unpublished but widely-cited

discussion paper (Allen 2005). However, it has formed the basis of the food

calculations which Overton and Campbell have undertaken with Stephen Broadberry,

Alexander Klein and Bas van Leeuwen for their forthcoming study of British

economic growth from 1270 to 1870 (Broadberry, Campbell, Klein, Overton and Van

Leeuwen, forthcoming). This study incorporates a number of changes to Overton

and Campbell's original estimates and combines them with estimates of the number

of calories derived from non-arable sources. The most recent version (5 August

2013) suggests that aggregate consumption rose after the Black Death and reached a peak of 2467 calories per person per day during the 1380 s. This level was not regained until the 1860 s.

A further attempt to estimate food production and consumption levels was undertaken by Robert Allen in 2005. Allen estimated the number of calories generated by domestically-provided and imported foodstuffs in 1300, 1500, 1700, 1750, 1800 and 1850. His calculations suggested that per capita food consumption almost doubled between 1300 and 1500. It fell slightly between 1500 and 1700 and rose dramatically between 1700 and 1750. It then declined even more dramatically over the course of the next century (Allen, 2005, p. 39).

Allen's estimates for the period after 1700 contrast sharply with those published by Robert Fogel. After comparing the number of calories available in England with the figure for France, he argued that 'England's supply of food per capita exceeded that of France by several hundred calories but was still exceedingly low by current standards'. He concluded that 'the prevalence of meagre diets in much of Europe, and the cycling of stature even in a country as bountiful in food as the United States, shows how persistent misery was down almost to the end of the 
This article is (C) Emerald Group Publishing and permission has been granted for this version to appear here

(http://strathprints.strath.ac.uk/50435/). Emerald does not grant permission for this article to be further copied/distributed or hosted elsewhere without the express permission from Emerald Group Publishing Limited.

nineteenth century and how diverse were the factors that prolonged misery' (Fogel,

2004, pp. 8-19).

Although Fogel's initial estimates have been cited on a number of occasions (see e.g. Kelly and Ó Gráda, 2013a, p. 1137; Meredith and Oxley, 2014, p. 165), it is important to remember that they were also provisional. He did not provide any information about the sources on which they were based and referred readers to a forthcoming publication for further details (Fogel, 2004, p. 9). When this study appeared, it included a number of significant revisions. However, the new figures continued to suggest that 'a significant proportion of the British population may not have had access to the number of calories which they needed to undertake physically-demanding work on a regular basis at the start of the nineteenth century' (Floud et al., 2011 , p. 168).

We can gain a more detailed picture of the differences between Fogel's original estimates and those which were subsequently published from Table 1. Fogel's original estimates suggested that average calorie consumption rose by between 60 and 70 calories per day between 1700 and 1750, and again between 1750 and 1800. The pace of change accelerated after 1800 and increased rapidly after 1850 . By contrast, Floud et al. presented two different sets of estimates, based on different assumptions about the productivity of cereal crops between 1750 and 1850. The first set of figures suggested that average consumption fell during the first half of the eighteenth century whereas the second set of figures showed a very minor increase. However, both sets of figures suggested that average calorie consumption rose from 1750 onwards.

Table 1. Average per capita food consumption, 1700-1850: Fogel versus Floud et al. 
This article is (c) Emerald Group Publishing and permission has been granted for this version to appear here

(http://strathprints.strath.ac.uk/50435/). Emerald does not grant permission for this article to be further copied/distributed or hosted elsewhere without the express permission from Emerald Group Publishing Limited.

\begin{tabular}{lccc}
\hline & Estimate A & Estimate B \\
\hline 1700 & 2095 & 2229 & 2229 \\
1750 & 2168 & 2100 & 2237 \\
1800 & 2237 & 2472 & 2439 \\
1850 & 2362 & 2504 & 2544 \\
$1909 / 13$ & 2857 & 2977 & 2977 \\
\hline
\end{tabular}

Sources: Fogel, 2004, p. 9; Floud et al., 2011 , p. 160.

Although Floud et al. provided much more detailed information about the sources which lay behind their figures, their data also included a spreadsheet error, first identified by Deborah Oxley, which has significant implications for their estimation of the number of calories obtained from domestically-produced wheat in 1750. This error led them to underestimate the number of calories derived from this source by between 227 calories (Estimate A) and 278 calories (Estimate B). The inclusion of the corrected figures has a significant effect on the pattern of change during the eighteenth century and sharpens the difference between the two estimates. The corrected version of Estimate A suggests that calorie consumption rose continuously across the whole of the period from 1700 to 1850 . The corrected version of Estimate B implies that consumption rose between 1700 and 1750 , but fell between 1750 and 1800 (see Table 2).

As a number of commentators have pointed out, there are strong methodological similarities between Floud et al.'s work and that of Craig Muldrew. However, their results are very different. Whereas Floud and his co-authors argued that average calorie consumption rose from 2229 calories per person per day in 1700 to between 2439 and 2472 calories a century later, Muldrew (2011, p. 156) claimed that the number of calories supplied by grain products alone in 1700 was 2682 , and that the number of calories from all foodstuffs was 3579 . He also suggested that total food availability increased by more than 41 per cent between 1700 and 1770 , before falling by just over 21 per cent between 1770 and 1800 . 
This article is (c) Emerald Group Publishing and permission has been granted for this version to appear here

(http://strathprints.strath.ac.uk/50435/). Emerald does not grant permission for this article to be further copied/distributed or hosted elsewhere without the express permission from Emerald Group Publishing Limited.

Unfortunately, his figures did not extend beyond that date. However, they implied

that average daily calorie consumption per head in 1800 was exactly one thousand calories greater than the figure which Floud et al. derived from the data published by the Royal Society for the period 1909-13 (Floud et al., 2011, p. 160).

A number of authors have attempted to steer a middle way between these conflicting estimates. Although Morgan Kelly and Cormac Ó Gráda drew on some of the work published by Fogel and Floud et al., they focused most of their attention on the estimates of Broadberry et al. and Muldrew. After looking at the individual components of each set of estimates, they concluded that, whilst Muldrew's figures were clearly 'over-generous', those published by Broadberry and his coauthors were in need of 'upward revision' (Kelly and Ó Gráda, 2013a, pp. 1150, $1153 ; 2013 b$, p. 2). However, even with these revisions, their own suggestions still included quite a wide margin of error for particular years (see Appendix 1).

A rather different approach has been taken by David Meredith and Deborah Oxley (2014). They compared Muldrew's estimates with those published by Floud et al., and then experimented with different scenarios in which they applied the conversion ratios employed by the different authors to each other's data. They also compared the results with a reassessment of anthropometric trends and data from household budgets. They concluded that the most plausible scenario was one in which Floud et al.'s conversion ratios (for seeding, animal feed, processing and wastage) were applied to Muldrew's data for the eighteenth century and then merged with Floud et al.'s own results for the nineteenth and early-twentieth centuries. These calculations led to a substantial reduction in the size of Muldrew's eighteenth-century estimates, but still left room for a sharp fall in food availability between circa 1770 and 1850 . 
Table 2. Calories derived from domestically-produced wheat and other sources in England and Wales, 1700-1850: Published and revised estimates

Published figures: Estimate A

\begin{tabular}{|c|c|c|c|c|c|c|c|c|c|c|}
\hline & $\begin{array}{c}\text { Domestically- } \\
\text { produced } \\
\text { wheat }\end{array}$ & $\begin{array}{l}\text { Other } \\
\text { domestically- } \\
\text { produced } \\
\text { cereals and } \\
\text { pulses }\end{array}$ & $\begin{array}{l}\text { Total calories } \\
\text { from } \\
\text { domestically- } \\
\text { produced } \\
\text { cereals and } \\
\text { pulses }\end{array}$ & $\begin{array}{l}\text { Calories } \\
\text { from all } \\
\text { other } \\
\text { sources } \\
\text { (including } \\
\text { imports) }\end{array}$ & $\begin{array}{c}\text { Total } \\
\text { calories }\end{array}$ & $\begin{array}{l}\text { Domestically- } \\
\text { produced } \\
\text { wheat }\end{array}$ & $\begin{array}{c}\text { Other } \\
\text { domestically- } \\
\text { produced } \\
\text { cereals and } \\
\text { pulses }\end{array}$ & $\begin{array}{l}\text { Total calories } \\
\text { from } \\
\text { domestically- } \\
\text { produced } \\
\text { cereals and } \\
\text { pulses }\end{array}$ & $\begin{array}{l}\text { Calories } \\
\text { from all } \\
\text { other } \\
\text { sources } \\
\text { (including } \\
\text { imports) }\end{array}$ & $\begin{array}{c}\text { Total } \\
\text { calories }\end{array}$ \\
\hline 1700 & 502.43 & $1,063.94$ & $1,566.37$ & 662.26 & $2,228.63$ & 502.43 & $1,063.94$ & $1,566.37$ & 662.26 & $2,228.63$ \\
\hline 1750 & 430.09 & 845.03 & $1,275.12$ & 824.84 & $2,099.96$ & 657.28 & 845.03 & $1,502.32$ & 824.84 & $2,327.16$ \\
\hline 1800 & 732.04 & 634.08 & $1,366.12$ & $1,106.00$ & $2,472.12$ & 732.04 & 634.08 & $1,366.12$ & $1,106.00$ & $2,472.12$ \\
\hline \multirow[t]{3}{*}{1850} & 706.28 & 375.22 & $1,081.50$ & $1,422.58$ & $2,504.08$ & 706.28 & 375.22 & $1,081.50$ & $1,422.58$ & $2,504.08$ \\
\hline & \multicolumn{5}{|c|}{ Published figures: Estimate B } & \multicolumn{5}{|c|}{ Corrected figures: Estimate $\mathrm{B}$} \\
\hline & $\begin{array}{l}\text { Domestically- } \\
\text { produced } \\
\text { wheat }\end{array}$ & $\begin{array}{l}\text { Other } \\
\text { domestically- } \\
\text { produced } \\
\text { cereals and } \\
\text { pulses }\end{array}$ & $\begin{array}{l}\text { Total calories } \\
\text { from } \\
\text { domestically- } \\
\text { produced } \\
\text { cereals and } \\
\text { pulses }\end{array}$ & $\begin{array}{l}\text { Calories } \\
\text { from all } \\
\text { other } \\
\text { sources } \\
\text { (including } \\
\text { imports) }\end{array}$ & $\begin{array}{c}\text { Total } \\
\text { calories }\end{array}$ & $\begin{array}{l}\text { Domestically- } \\
\text { produced } \\
\text { wheat }\end{array}$ & $\begin{array}{l}\text { Other } \\
\text { domestically- } \\
\text { produced } \\
\text { cereals and } \\
\text { pulses }\end{array}$ & $\begin{array}{l}\text { Total calories } \\
\text { from } \\
\text { domestically- } \\
\text { produced } \\
\text { cereals and } \\
\text { pulses }\end{array}$ & $\begin{array}{l}\text { Calories } \\
\text { from all } \\
\text { other } \\
\text { sources } \\
\text { (including } \\
\text { imports) }\end{array}$ & $\begin{array}{c}\text { Total } \\
\text { calories }\end{array}$ \\
\hline 1700 & 502.43 & $1,063.94$ & $1,566.37$ & 662.26 & $2,228.63$ & 502.43 & $1,063.94$ & $1,566.37$ & 662.26 & $2,228.63$ \\
\hline 1750 & 526.28 & 886.19 & $1,412.46$ & 824.85 & $2,237.31$ & 804.29 & 886.19 & $1,690.48$ & 824.84 & $2,515.32$ \\
\hline 1800 & 717.77 & 615.12 & $1,332.89$ & $1,106.00$ & $2,438.89$ & 717.77 & 615.12 & $1,332.89$ & $1,106.00$ & $2,438.89$ \\
\hline 1850 & 729.03 & 392.74 & $1,121.77$ & $1,422.60$ & $2,544.37$ & 729.03 & 392.74 & $1,121.77$ & $1,422.60$ & $2,544.37$ \\
\hline
\end{tabular}

Source: Floud, Fogel, Harris and Hong, 2011 , pp. 160,205-9.

Corrected figures: Estimate A 
This article is (c) Emerald Group Publishing and permission has been granted for this version to appear here

(http://strathprints.strath.ac.uk/50435/). Emerald does not grant permission for this article to be further copied/distributed or hosted elsewhere without the express permission from Emerald Group Publishing Limited.

Although these papers cover a number of different periods, the main areas of divergence concentrate on the eighteenth and nineteenth centuries. Within this period, it is possible to identify two broad schools of thought (see Figure 1 and Appendix 1). The first school, represented particularly by Broadberry et al. and Floud et al., suggests that food availability was generally low, and that there was relatively little change before the early-to-middle years of the nineteenth century. The second school, represented especially by Robert Allen and Craig Muldrew, argues that food availability was much greater during the first $50-70$ years of the eighteenth century, and fell sharply between circa 1770 and 1850 . In order to investigate these issues further, we begin by looking more closely at the similarities and differences between the accounts presented by Broadberry et al. and Floud et al.. We then contrast Floud et al.'s estimates with those published by Muldrew before looking at the compromise position proposed by Meredith and Oxley.

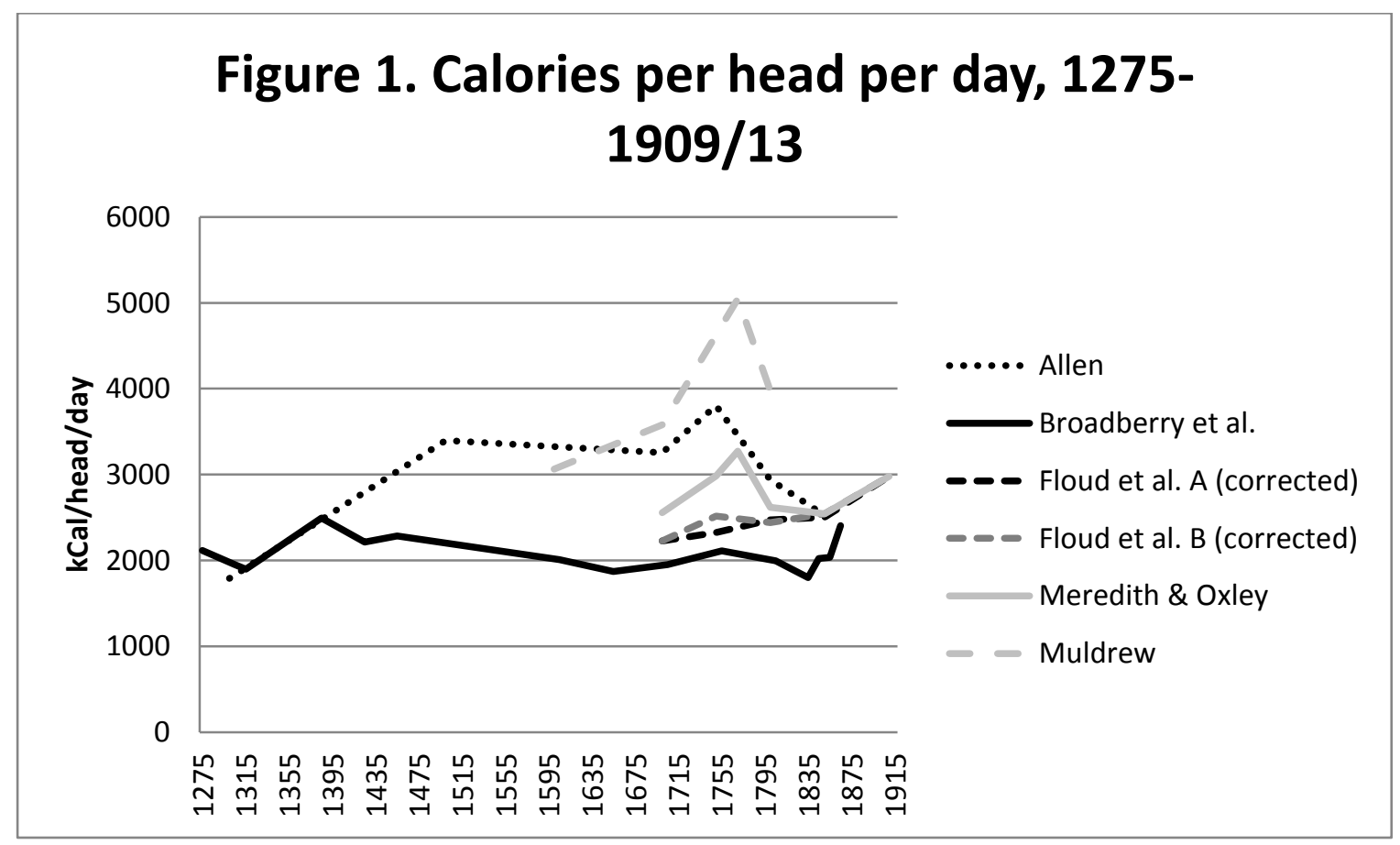

Sources: See Appendix 1. 
This article is (c) Emerald Group Publishing and permission has been granted for this version to appear here

(http://strathprints.strath.ac.uk/50435/). Emerald does not grant permission for this article to be further copied/distributed or hosted elsewhere without the express permission from Emerald Group Publishing Limited.

\section{Optimists and pessimists}

Although Floud et al. and Broadberry et al. reached similar conclusions, they did not necessarily reach them in the same way, and their results were not identical. In view of this, it is appropriate to consider the different routes taken towards their final figures in more detail.

\subsection{Land under cultivation}

Floud et al. based their estimates on the amount of land under cultivation on figures originally published by Chartres (1985, p. 444), Allen (1994, p. 112) and Holderness (1989, p. 145). Although both Chartres (1985, p. 145) and Holderness (1989, pp. 126, 139, 142; see also Allen, 1994, p. 103) appear to have been referring to the whole of England and Wales, they reached different conclusions about the amount of land under cultivation in 1750. Floud et al. (2011, pp. 205-7) followed Allen (1994, p. 112) in preferring Holderness' figures, partly because Chartres did not attempt to estimate the amount of land used for beans and peas, and partly to provide continuity with Holderness' figures for 1800 and 1850 . However, when Allen returned to the subject in 2005, he used Chartres' figures (Allen 2005, p. 28). If Floud et al. had also used these figures, their overall estimate for the number of calories consumed per person per day in 1750 would have been between 138 calories (Estimate A) and 144 calories (Estimate B) higher.

Floud et al.'s figures can also be compared with those of Broadberry et al. in Table 3, although Broadberry et al.'s figures appear to refer to England only. Their figures suggest that the total amount of land devoted to the cultivation of wheat, rye, barley, oats and pulses was less than the figures published by Floud et al. for 1700 and 1750, but greater than Floud et al.'s figures for 1800 . Whereas Floud et al. believed that the land devoted to these crops increased between 1800 and 1850 , 
This article is (C) Emerald Group Publishing and permission has been granted for this version to appear here

(http://strathprints.strath.ac.uk/50435/). Emerald does not grant permission for this article to be further copied/distributed or hosted elsewhere without the express permission from Emerald Group Publishing Limited.

Broadberry et al. suggested a decline. However, they also claimed that the acreage

devoted to other crops increased, so that the total amount of land under cultivation rose by just under 1.2 million acres.

\subsection{Yields per acre}

Floud et al. (2011) published two different sets of estimates for yields per acre.

Their initial estimates were based on the yields reported by Chartres (1985, p. 444) and Allen (1994, p. 112) for 1700, and by Holderness (1989, p. 145) for 1750 , 1800 and 1850 . They also published a second set of estimates, based on work by Turner et al. (2001, pp. 129, 153, 158, 163-4) for the period from 1750 onwards. However, Turner and his co-authors did not publish estimates for the productivity of rye in 1750 , and their results may not have been entirely representative (Thirsk, 2002). The corrected version of Floud et al.'s study suggests that the first of these two estimates may therefore provide a more appropriate guide to the general trend over the period as a whole (Floud et al., forthcoming). 
This article is (c) Emerald Group Publishing and permission has been granted for this version to appear here

(http://strathprints.strath.ac.uk/50435/). Emerald does not grant permission for this article to be further copied/distributed or hosted elsewhere without the express permission from Emerald Group Publishing Limited.

Table 3. Land under cultivation: Broadberry et al. versus Floud et al.

\begin{tabular}{lcccccc} 
& 1700 & 1750 & 1800 & 1830 & 1850 & 1871 \\
\hline & & \multicolumn{7}{c}{ Broadberry } & et al. \\
\hline Wheat & 1.99 & 1.95 & 2.97 & 2.08 & - & 3.31 \\
Rye/Maslin & 0.42 & 0.06 & 0.06 & 0.06 & - & 0.06 \\
Barley/Dredge & 1.82 & 1.50 & 1.62 & 1.82 & - & 1.96 \\
Oats & 1.15 & 1.82 & 1.97 & 1.39 & - & 1.45 \\
Pulses & 0.98 & 0.98 & 0.83 & 0.63 & - & 0.90 \\
\hline Total Cereals & 6.36 & 6.31 & 7.45 & 5.98 & - & 7.68 \\
and Pulses & & & & & & \\
\hline Potatoes & 0.00 & 0.08 & 0.17 & 0.26 & - & 0.39 \\
Other Crops & 1.30 & 2.53 & 2.90 & 4.46 & - & 5.28 \\
\hline Total Sown & 7.66 & 8.92 & 10.52 & 10.70 & - & 13.35 \\
\hline Fallow Arable & 1.91 & 1.59 & 1.28 & 1.30 & - & 0.48 \\
\hline Total Arable & 9.57 & 10.51 & 11.80 & 12.00 & - & 13.83 \\
\hline & & & Floud et & al. & & \\
\hline Wheat & 1.36 & 1.80 & 2.50 & - & 3.60 & - \\
Rye/Maslin & 0.89 & 0.50 & 0.30 & - & 0.10 & - \\
Barley/Dredge & 1.90 & 1.40 & 1.30 & - & 1.50 & - \\
Oats & 1.22 & 2.00 & 2.00 & - & 2.00 & - \\
Pulses & 1.30 & 1.00 & 1.20 & - & 1.00 & - \\
\hline Total Cereals & 6.68 & 6.70 & 7.30 & - & 8.20 & - \\
and Pulses & & & & & & \\
\hline
\end{tabular}

Sources: Broadberry et al., 2011 , p. 36; Floud et al., 201 1, pp. 205-7.

Broadberry et al. published an initial, and fuller, version of their latest estimates in 2011 . This paper forms the basis of the chapter on 'Consumption' in their forthcoming volume. It is difficult to compare their estimates directly with those published by Floud et al. because their figures are for crop yields net of seed and it is not possible to estimate gross yields directly from the information in their paper. However, we can infer the figures for wheat, rye, barley and oats from the estimates published by Overton and Campbell in 1996. The data in Table 4 suggest that the two sets of authors reached broadly similar conclusions about the productivity of wheat, but Broadberry and his coauthors were generally more pessimistic about the productivity of barley and oats, and probably also more 
This article is (c) Emerald Group Publishing and permission has been granted for this version to appear here

(http://strathprints.strath.ac.uk/50435/). Emerald does not grant permission for this article to be further copied/distributed or hosted elsewhere without the express permission from Emerald Group Publishing Limited.

pessimistic about the productivity of beans and peas. They proposed higher

estimates for the productivity of rye and maslin in 1700 and 1750, but lower

estimates for these crops in 1800 and 1850.

Table 4. Yields per acre: Broadberry et al. versus Floud et al.

Floud et al. A.

\begin{tabular}{|c|c|c|c|c|c|c|c|c|c|c|}
\hline & \multicolumn{2}{|c|}{ Wheat } & \multicolumn{2}{|c|}{ Rye/Maslin } & \multicolumn{2}{|c|}{ Barley/Dredge } & \multicolumn{2}{|c|}{ Oats } & \multicolumn{2}{|c|}{ Beans and Peas } \\
\hline & Gross & Net & Gross & Net & Gross & Net & Gross & Net & Gross & Net \\
\hline 1700 & 16.00 & - & 17.00 & - & 23.00 & - & 24.00 & - & 20.00 & - \\
\hline 1750 & 18.00 & - & 18.00 & - & 25.00 & - & 28.00 & - & 28.00 & - \\
\hline 1800 & 21.50 & - & 26.00 & - & 30.00 & - & 35.00 & - & 28.00 & - \\
\hline \multirow[t]{2}{*}{1850} & 28.00 & - & 28.00 & - & 36.50 & - & 40.00 & - & 30.00 & - \\
\hline & \multicolumn{10}{|c|}{ Floud et al. B. } \\
\hline 1700 & 16.00 & - & 17.00 & - & 23.00 & - & 24.00 & - & 20.00 & - \\
\hline 1750 & 22.00 & - & 18.00 & - & 24.80 & - & 36.70 & - & 21.80 & - \\
\hline 1800 & 21.10 & - & 23.40 & - & 29.20 & - & 37.40 & - & 22.00 & - \\
\hline \multirow[t]{2}{*}{1850} & 28.90 & - & 27.80 & - & 36.40 & - & 47.40 & - & 29.60 & - \\
\hline & \multicolumn{10}{|c|}{ Broadberry et al. } \\
\hline $1700 / 09$ & 15.40 & 12.90 & 20.45 & 17.95 & 19.75 & 15.75 & 12.73 & 8.73 & - & 9.88 \\
\hline $1750 / 59$ & 17.65 & 15.15 & 19.34 & 16.84 & 23.15 & 19.15 & 24.46 & 20.46 & - & 10.36 \\
\hline $1800 / 09$ & 18.96 & 16.46 & 22.82 & 20.32 & 26.46 & 22.46 & 26.85 & 22.85 & - & 16.13 \\
\hline $1850 / 59$ & 26.47 & 23.97 & 22.63 & 20.13 & 30.58 & 26.58 & 34.26 & 30.26 & - & 16.58 \\
\hline
\end{tabular}

Sources: Broadberry et al., 201 1, p. 36; Overton and Campbell, 1996, p. 294; 2006, p. 41; Floud et al., 2011, pp. 205-9.

\subsection{Calories from cereals and pulses}

Both Broadberry et al. and Floud et al. drew on McCance and Widdowson's (1960)

exhaustive account of The composition of foods when estimating calorie values.

However, as we can see from Table 5, they nevertheless reached slightly different conclusions about the calorific value of barley and oats. Broadberry et al. also appear to have used slightly lower values for beans and peas. 
This article is (c) Emerald Group Publishing and permission has been granted for this version to appear here

(http://strathprints.strath.ac.uk/50435/). Emerald does not grant permission for this article to be further copied/distributed or hosted elsewhere without the express permission from Emerald Group Publishing Limited.

Table 5. Calorie values: Broadberry et al. versus Floud et al.

Broadberry et al.

Floud et al.

\begin{tabular}{lcccc}
\hline & $\begin{array}{c}\text { kCal per } \\
\text { bushel }\end{array}$ & $\begin{array}{c}\text { Pounds per } \\
\text { bushel (from } \\
\text { Floud } \text { et al.) }\end{array}$ & $\begin{array}{c}\text { kCal per } \\
\text { pound }\end{array}$ & Kcal per pound \\
\hline Wheat & 86,667 & 57 & 1,520 & 1,520 \\
Rye & 83,810 & 55 & 1,524 & 1,520 \\
Barley & 71,429 & 49 & 1,458 & 1,632 \\
Oats & 63,889 & 38 & 1,681 & 1,824 \\
Beans and Peas & 24,000 & 60 & 400 & 480 \\
\hline
\end{tabular}

Notes. These figures have been calculated from Broadberry et al., forthcoming: Tables 8.1 and 8.5. The figures for wheat, rye, barley and oats are very similar to those published by Kelly and Ó Gráda (2013, p. 1138).

Sources: Broadberry et al., forthcoming: Tables 8.1, 8.5; Floud et al., 201 1, pp. 2059.

\subsection{Potatoes}

It is generally agreed that potatoes formed an increasingly important part of the national diet during the eighteenth and nineteenth centuries but the details remain contentious. One of the main problems in comparing the various estimates which have been produced is that different authors have provided different amounts of information about the underlying calculations on which their conclusions are based, as Table 6 suggests. However, the main sources of disagreement are likely to be associated with differences concerning the amount of land under cultivation, the definition of the area under consideration and the figures used to estimate yields per acre. 
This article is (c) Emerald Group Publishing and permission has been granted for this version to appear here

(http://strathprints.strath.ac.uk/50435/). Emerald does not grant permission for this article to be further copied/distributed or hosted elsewhere without the express permission from Emerald Group Publishing Limited.

Table 6. Potato consumption: details for comparing estimates

\begin{tabular}{|c|c|c|c|c|c|c|}
\hline & $\begin{array}{l}\text { Land under } \\
\text { cultivation }\end{array}$ & Production per acre & Lbs per bushel & Calories per unit & $\begin{array}{l}\text { Calories } \\
\text { per acre }\end{array}$ & $\begin{array}{l}\text { Population/Area } \\
\text { covered }\end{array}$ \\
\hline Holderness 1989: 144-6 & $1750,1800,1850$ & 150 bushels per acre & Not specified & - & - & England and Wales \\
\hline Allen 2005: Tables 1, 5 & $\begin{array}{l}1700,1750,1800 \\
1850\end{array}$ & 150 bushels per acre & Not specified & Not specified & - & England and Wales \\
\hline $\begin{array}{l}\text { Overton and Campbell } \\
\text { 1996; 2006: Tables 5, } 9\end{array}$ & $\begin{array}{l}1700,1800,1830 \\
1871\end{array}$ & Not specified & Not specified & $\begin{array}{l}368 \text { calories per } \\
\text { pound }\end{array}$ & $\begin{array}{l}\text { Gross } \\
\text { and net } \\
\text { figures }\end{array}$ & $\begin{array}{l}\text { England/England } \\
\text { and Wales }\end{array}$ \\
\hline $\begin{array}{l}\text { Broadberry et al. } 2011 \text { : } \\
\text { Tables } 1,2,3\end{array}$ & $\begin{array}{l}1700,1750,1800 \\
1830,1871\end{array}$ & $\begin{array}{l}\text { Table 2: } 150 \text { bushels } \\
\text { per acre; Table } 3: \\
\text { Output net of seed } \\
\text { for } 1700 / 09 \\
1750 / 59,1800 / 09 \\
1850 / 59,1861 / 70\end{array}$ & Not specified & Not specified & - & England \\
\hline $\begin{array}{l}\text { Broadberry et al., } \\
\text { forthcoming, Table } 8.5\end{array}$ & - & - & - & $\begin{array}{l}368 \text { calories per } \\
\text { pound }\end{array}$ & - & England \\
\hline Salaman 1949: 612-3 & $\begin{array}{l}1775,1795,1814, \\
1838,1851,1866, \\
1871,1881,1891, \\
1901,1911,1914\end{array}$ & 6 tons per acre & $\mathrm{n} / \mathrm{a}$ & $n / a$ & $\begin{array}{l}\text { Net } \\
\text { figures }\end{array}$ & England and Wales \\
\hline Floud et al. $2011: 221$ & $\begin{array}{l}1700,1750,1800 \\
1850,1909 / 13\end{array}$ & $\begin{array}{l}\text { Inferred from } \\
\text { Salaman }\end{array}$ & $\begin{array}{l}\text { Inferred from } \\
\text { Salaman }\end{array}$ & $\begin{array}{l}23 \text { calories per } \\
\text { ounce }(=368 \\
\text { calories per } \\
\text { pound })\end{array}$ & $\begin{array}{l}\text { Net } \\
\text { figures }\end{array}$ & England and Wales \\
\hline
\end{tabular}

Sources: See table.

\subsubsection{An eighteenth-century peak?}

Allen (2005, p. 28) argued that the amount of land devoted to the cultivation of potatoes throughout England and Wales increased from 0.1 million acres in 1700 to 0.2 million in 1750, 0.3 million in 1800 and 0.4 million in 1850 , and that the average acre yielded 150 bushels per year. These figures were based on the estimates published by Holderness (1989, pp. 144-6) for the period from 1750 onwards. However, other authors thought that there was very little evidence of potato consumption before the second half of the eighteenth century (see e.g. Salamon, 1949, p. 537), and Holderness himself had reservations about the figures he had published. He explained that 'we have assigned a value to the output of all root and rotational grass crops in the manner of Young and McCulloch, but only for the sake of completeness' and that 'quite apart from the question of ... accuracy, much of this sum needs to be expunged from an account of gross [agricultural] product' (Holderness, 1989, p. 146). 
This article is (c) Emerald Group Publishing and permission has been granted for this version to appear here

(http://strathprints.strath.ac.uk/50435/). Emerald does not grant permission for this article to be further copied/distributed or hosted elsewhere without the express permission from Emerald Group Publishing Limited.

Although Allen derived his figures for the amount of land under cultivation

and the number of bushels per acre from Holderness, he did not specify how many pounds were contained in each bushel, or how many calories were provided by each pound. When Kelly and Ó Gráda (2013b, p. 1) compared his figures with those published by Broadberry et al., they assumed that each bushel contained 60 pounds and that each pound provided 368 calories. They also assumed that only five-sixths of the total crop was used for human consumption, with the remainder being used for seed. If these figures are applied to Allen's data, the results suggest that net consumption would have risen from 139 calories in 1700 to 244 in 1750 and 246 in 1800 , before falling to 169 calories in 1850 . If we substitute the figures which Overton and Campbell used to compare gross and net yields in 1800 and 1830 and apply them to Allen's data for the whole of the period, consumption levels would rise to 150 calories, 264 calories, 266 calories and 182 calories respectively (see Table 7).

Table 7. Potato consumption: Allen

\begin{tabular}{|c|c|c|c|c|c|c|c|c|}
\hline & $\begin{array}{l}\text { Acres } \\
(\mathrm{mn})\end{array}$ & Bushels & $\begin{array}{l}\text { Pounds } \\
\text { per } \\
\text { bushel }\end{array}$ & $\begin{array}{l}\text { Calories per } \\
\text { pound }\end{array}$ & $\begin{array}{c}\text { Population (England } \\
\text { and Wales) }\end{array}$ & \multicolumn{3}{|c|}{ Calories per person per day } \\
\hline & & & & & & Gross & & \\
\hline & & & & & & & $\begin{array}{c}\text { Extraction } \\
\text { rate } \\
=83.33 \%\end{array}$ & $\begin{array}{l}\text { Extraction } \\
\text { rate }=90 \%\end{array}$ \\
\hline 1700 & 0.1 & 150 & 60 & 368 & $5,444,426$ & 166.67 & 138.89 & 150.00 \\
\hline 1750 & 0.2 & 150 & 60 & 368 & $6,192,091$ & 293.08 & 244.24 & 263.77 \\
\hline 1800 & 0.3 & 150 & 60 & 368 & $9,223,320$ & 295.14 & 245.95 & 265.63 \\
\hline 1850 & 0.4 & 150 & 60 & 368 & $17,928,000$ & 202.45 & 168.71 & 182.21 \\
\hline
\end{tabular}

Sources: Acres and bushels: Allen, 2005, p. 28; Pounds per bushel and calories per pound: Kelly and Ó Gráda, 2013 b, p. 1; Population: Floud et al., 2011 , Table D2; Net extraction rates: Kelly and Ó Gráda, $2013 b$, p. 1; Overton and Campbell, 1996, p. 294; 2006, p. 41.

\subsubsection{An early-nineteenth century peak?}

Whilst Allen's figures imply that the average daily consumption of potatoes peaked during the second half of the eighteenth century, others suggest that it continued 
This article is (c) Emerald Group Publishing and permission has been granted for this version to appear here

(http://strathprints.strath.ac.uk/50435/). Emerald does not grant permission for this article to be further copied/distributed or hosted elsewhere without the express permission from Emerald Group Publishing Limited.

to rise during the early part of the nineteenth century. In their original paper,

Overton and Campbell (1996, p. 292; 2006, p. 37) published figures showing the number of acres under cultivation and the number of calories per acre in 1700 , 1800,1830 and 1871 . When these figures are divided by the population of England, they imply that average daily consumption rose between 1800 and 1830 and declined between 1830 and 1871 (see Table 8). ${ }^{1}$

Overton and Campbell derived their figures from Turner's analysis of the crop returns for 1801 and from the agricultural returns published by the Board of Trade seventy years later. As Turner (1981, p. 296-7) explained, the crop returns provided information regarding the crops grown in 44 English counties and 12 Welsh counties. The returns were incomplete but, when they were scaled up, they suggested that the amount of land devoted to potatoes was between 157,138 and 174,423 acres. Overton and Campbell (1996, p. 292; 2006, p. 37) appear to have used the mean of these two figures as the basis for their estimate that the total amount of land devoted to potatoes in 1800 was 0.16 million acres. They then estimated a figure for 1830 by interpolating between this figure and the figures published by the Board of Trade in $1871(0.16+[30 \times 0.23 / 71]=0.257)$. However, it is worth noting that, whereas Turner's figures referred to England and Wales, the figures which Overton and Campbell derived from the Agricultural Returns referred to England only. The published total for the whole of England and Wales was 443,384 acres, or 0.44 million acres (Parliamentary Papers, 1871, p. 24).

These figures also formed the basis of the calculations which Overton and Campbell subsequently published with Broadberry, Klein and van Leeuwen (Broadberry et al., 2011 , p. 36). In their later publication, they raised the figure for 1800 from 0.16 million acres to 0.17 million $([157,138+174,423] / 2=165,781)$

This interpretation is based on the assumptions that all data refer to England only; that the number of pounds per bushel remained constant; and that the extraction rate was 90 per cent. As we shall see, all of these assumptions could be questioned. 
This article is (c) Emerald Group Publishing and permission has been granted for this version to appear here

(http://strathprints.strath.ac.uk/50435/). Emerald does not grant permission for this article to be further copied/distributed or hosted elsewhere without the express permission from Emerald Group Publishing Limited.

and then used interpolation to estimate a figure for $1750(165,781 / 2=82,915)$.

When these figures were combined with Overton and Campbell's earlier calculations, they implied that the average daily consumption of calories from potatoes in 1750 was approximately 114 calories (Table 8 ).

Although these figures may be regarded, in some respects, as an advance on Holderness' and Allen's figures, they raise further questions of their own. As we have already seen, the geographical coverage of the different estimates oscillates between England and England and Wales, and the figures for both 1750 and 1830 are based on interpolation rather than observation. However, there are also problems with the way in which Overton and Campbell measured the total yield and with their efforts to estimate net extraction rates. As we can see from Table 8 , their overall figures imply that the number of pounds per bushel rose from 60 in 1800 and 61 in 1830 to 76 in 1871 (col. 7), whilst the extraction rate rose from approximately 90 per cent in 1800 and 1830 to 100 per cent at the start of the 1870s (col. 4).

These problems mean that we should exercise a degree of caution before attaching too much weight to the detail of these figures. If we hold the number of pounds per bushel and the extraction rates constant and assume that the figures only refer to England, they imply that average consumption rose from zero calories in 1700 and 114 in 1750 to 161 in 1800 and 162 in 1830 , before falling to 148 in 1871 (Table 8 , col. 12). If we divide the total number of calories in 1800 by the population of England and Wales, rather than England alone, the figure for that year falls to 151 calories (Table 8, col. 16, row 1800B). If we include the Board of Trade's figures for England and Wales and divide the net output by the population of both countries, average daily consumption in 1871 rises to 158 calories (Table 8 , col. 16, row 1871B). If we use Overton and Campbell's own figures, and assume 
This article is (c) Emerald Group Publishing and permission has been granted for this version to appear here

(http://strathprints.strath.ac.uk/50435/). Emerald does not grant permission for this article to be further copied/distributed or hosted elsewhere without the express permission from Emerald Group Publishing Limited.

that there were 76 pounds in each bushel in 1871 and a net extraction rate of 100

per cent, net consumption rises to 210 calories in England (Table 8, col. 14, row

1871B) and 224 in England and Wales as a whole (Table 8, col. 18, row 1871B).

\subsubsection{Weights and measures}

As the previous paragraphs have demonstrated, there is a fair amount of uncertainty surrounding the interpretation of historical weights and measures. Kelly and Ó Gráda (2013b, p. 1) assumed that each bushel contained 60 pounds, and this is consistent with the figures which Overton and Campbell (1996, p. 294; 2006 , p. 41 ) used to estimate the total yield in 1800 and 1830 , but their figures for 1871 imply that each bushel contained 76.45 pounds. Overton and Campbell also assumed that each acre produced 150 bushels of crop, which implies that the average yield ranged from 9000 pounds in 1800 and 1830 to 11,465 pounds in 1871. By contrast, Salaman (1949, p. 613) claimed that each acre produced six tons, or 13,440 pounds, for human consumption. 
This article is $\odot$ Emerald Group Publishing and permission has been granted for this version to appear here (http://strathprints.strath.ac.uk/50435/). Emerald does not grant permission for this article to be further copied/distributed or hosted elsewhere without the express permission from Emerald Group Publishing Limited.

Table 8. Potato consumption: Overton and Campbell, and Broadberry et al.

\begin{tabular}{|c|c|c|c|c|c|c|c|c|c|c|c|c|c|c|c|c|c|c|}
\hline & \multirow{4}{*}{ Acres } & \multicolumn{3}{|c|}{ Calories per acre } & \multirow[t]{2}{*}{$\begin{array}{l}\text { Bushels } \\
\text { per acre }\end{array}$} & \multirow{2}{*}{\multicolumn{3}{|c|}{$\begin{array}{c}\text { Calories } \\
\text { per } \\
\text { pound }\end{array}$}} & \multicolumn{2}{|c|}{ Population } & \multicolumn{8}{|c|}{ Calories per person per day } \\
\hline & & \multirow[t]{3}{*}{ Gross } & \multirow[t]{3}{*}{ Net } & \multirow[t]{3}{*}{$\begin{array}{c}\text { Extraction } \\
\text { rate }\end{array}$} & & & & & \multirow[t]{3}{*}{ England } & \multirow[t]{3}{*}{$\begin{array}{c}\text { England } \\
\text { and Wales }\end{array}$} & \multicolumn{4}{|c|}{ England } & \multicolumn{4}{|c|}{ England and Wales } \\
\hline & & & & & & \multirow{2}{*}{ Constant } & \multirow{2}{*}{ Derived } & & & & \multicolumn{2}{|c|}{ Constant Ibs/bushel } & \multicolumn{2}{|c|}{ Derived Ibs/bushel } & \multicolumn{2}{|c|}{ Constant Ibs/bushel } & \multicolumn{2}{|c|}{ Derived Ibs/bushe } \\
\hline & & & & & & & & & & & Gross & Net & Gross & Net & Gross & Net & Gross & Net \\
\hline & (1) & (2) & (3) & (4) & (5) & (6) & (7) & (8) & (9) & (10) & (11) & (12) & (13) & (14) & (15) & (16) & (17) & (18) \\
\hline 1700 & 0.00 & 0.00 & 0.00 & 90.00 & 150.00 & 60.00 & - & 368.00 & $5,026,877$ & $5,444,426$ & 0.00 & 0.00 & 0.00 & 0.00 & 0.00 & 0.00 & 0.00 & 0.00 \\
\hline 1750 & 0.08 & 3.31 & 2.98 & 90.00 & 150.00 & 60.00 & - & 368.00 & $5,739,364$ & $6,192,091$ & 126.48 & 113.83 & 0.00 & 0.00 & 117.23 & 105.51 & 0.00 & 0.00 \\
\hline $1800 \mathrm{~A}$ & 0.16 & 3.30 & 2.97 & 90.00 & 150.00 & 60.00 & 59.78 & 368.00 & $8,606,033$ & $9,223,320$ & 168.70 & 151.83 & 168.09 & 151.28 & 157.41 & 141.67 & 156.84 & 141.16 \\
\hline $1800 \mathrm{~B}$ & 0.17 & 3.30 & 2.97 & 90.00 & 150.00 & 60.00 & 59.78 & 368.00 & $8,606,033$ & $9,223,320$ & 179.24 & 161.32 & 178.59 & 160.73 & 167.25 & 150.52 & 166.64 & 149.98 \\
\hline 1830 & 0.26 & 3.37 & 3.03 & 90.00 & 150.00 & 60.00 & 61.05 & 368.00 & $13,105,539$ & $14,446,128$ & 180.02 & 162.02 & 183.17 & 164.85 & 163.31 & 146.98 & 166.17 & 149.56 \\
\hline $1871 \mathrm{~A}$ & 0.39 & 4.22 & 3.80 & 90.00 & 150.00 & 60.00 & 76.45 & 368.00 & $21,500,720$ & - & 164.59 & 148.13 & 209.72 & 188.74 & - & - & - & - \\
\hline $1871 \mathrm{~B}$ & 0.39 & 4.22 & 4.22 & 100.00 & 150.00 & 60.00 & 76.45 & 368.00 & $21,500,720$ & - & 164.59 & 164.59 & 209.72 & 209.72 & - & - & - & - \\
\hline $1871 \mathrm{~A}$ & 0.44 & 4.22 & 3.80 & 90.00 & 150.00 & 60.00 & 76.45 & 368.00 & - & $22,712,000$ & - & - & - & - & 175.79 & 158.21 & 223.98 & 201.59 \\
\hline $1871 \mathrm{~B}$ & 0.44 & 4.22 & 4.22 & 100.00 & 150.00 & 60.00 & 76.45 & 368.00 & . & $22,712,000$ & - & - & - & - & 175.79 & 175.79 & 223.98 & 223.98 \\
\hline
\end{tabular}

Notes and sources:

Col. 1. 1700, 1800A, 1830 and 1871A: Overton and Campbell (1996, p. 292; 2006, Table V); 1750 and 1800B: Broadberry et al. (201 1, p. 36 [Table 1]); 1871 B: Parliamentary Papers, 1871 , p. 24.

Cols. 2-3: Overton and Campbell, 1996, p. 294 (Table 9); 2006, p. 41 (Table IX). The figures for 1871A are based on the assumption that the extraction rate was 90 per cent. The figures for 1871 B are the ones reported in the published

Col. 4: Figures for 1700 and 1750 assume the same extraction rate as for 1800; figures for $1871 \mathrm{~A}$ assume the same extraction rate as 1830.

Col. 5: Broadberry et al., 2011 , p. 37 (Table 2).

Col. 6: Kelly and O Grada, 2013b, p. 1.

Col. 7. Calculated from cols. 1-3, 8 .

Col. 8. Overton and Campbell, 1996, p. 294 (Table 9); 2006, p. 41 (Table IX).

Col. 9: Wrigley and Schofield, 1981, pp. 533-5

Col. 10: 1700, 1750 and 1800: Floud et al., 201 1, Table D2; 1830: interpolated from Floud et al.'s figures for 1800 [1801] and 1850 [1851]; 1871: Mitchell, 1988 , Table 1.02.

Cols. 11-18: Calculated from cols. 1-10. 
This article is (c) Emerald Group Publishing and permission has been granted for this version to appear here

(http://strathprints.strath.ac.uk/50435/). Emerald does not grant permission for this article to be further copied/distributed or hosted elsewhere without the express permission from Emerald Group Publishing Limited.

There may be no certain way of resolving this issue. However, John (1989, pp. $1122-4)$ collected a vast amount of information about the weights and measures employed in different parts of England and Wales between 1750 and 1850 . He reported that the number of pounds in a bushel of potatoes varied from 56 pounds in Middlesex and 60 pounds in Surrey to 220 pounds in Cornwall, but these were not major potato-growing counties. The counties in his list which grew the greatest amounts of potatoes in 1871 were Cheshire and Lancashire, where a bushel contained approximately 90 pounds. This suggests that the figures used by Kelly and Ó Gráda are probably too low. On the other hand, if we accept the view that each acre produced 150 bushels and that each bushel contained around 90 pounds, this brings us very close to Salaman's claim that each acre yielded 13,440 pounds, or six tons $(13,440 / 150=89.6)$, even though Salaman appears to have regarded this as a net rather than gross figure (see Table 9).

Table 9. Definitions of a bushel of potatoes

\begin{tabular}{|c|c|c|c|}
\hline \multirow[t]{2}{*}{ County or region } & \multirow[t]{2}{*}{ Weight in pounds } & \multicolumn{2}{|c|}{ Area under cultivation in 1871} \\
\hline & & Acres & $\begin{array}{c}\% \text { of English and Welsh } \\
\text { total }\end{array}$ \\
\hline Cheshire & 90 pounds & 24,806 & 5.59 \\
\hline Cornwall & 220 pounds & 9,124 & 2.06 \\
\hline Cumberland (Penrith) & 20 gallons & 12,846 & 2.90 \\
\hline Derbyshire & Often 90 pounds & 3,842 & 0.87 \\
\hline Lancashire & $\begin{array}{l}\text { Generally } 90 \text { pounds not } \\
\text { cleaned }\end{array}$ & 39,056 & 8.81 \\
\hline Leicestershire & 80 pounds & 2,508 & 0.57 \\
\hline Middlesex & 56 pounds & 2,681 & 0.60 \\
\hline Surrey & 60 pounds & 4,082 & 0.92 \\
\hline Westmorland (Appleby) & 2 bushels & 2,051 & 0.46 \\
\hline North Wales/Anglesey & 74 pounds & 5,435 & 1.23 \\
\hline
\end{tabular}

Sources: Weight per bushel: John, 1989, pp. 1124-6; land under cultivation: Parliamentary Papers, 1871, pp. 50-54. 
This article is (c) Emerald Group Publishing and permission has been granted for this version to appear here

(http://strathprints.strath.ac.uk/50435/). Emerald does not grant permission for this article to be further copied/distributed or hosted elsewhere without the express permission from Emerald Group Publishing Limited.

\subsubsection{A mid-nineteenth century peak?}

As this section has shown, there are significant differences between the figures used by Allen, Overton and Campbell, and Broadberry et al. to estimate the number of calories derived from potatoes. If we assume that the figures for both gross and net yields per acre remained constant, Allen's data imply that consumption peaked during the second half of the eighteenth century, whereas Overton and Campbell and Broadberry et al.'s data suggest that consumption continued to increase during the first three decades of the nineteenth century. Floud et al.'s figures represent a further addition to the debate (see Table 10). They argued that consumption rose throughout the eighteenth century and the first half of the nineteenth century, reaching a peak in 1850 .

Table 10. Potato consumption: Floud et al.

\begin{tabular}{lrrrr} 
& $\begin{array}{c}\text { Area under } \\
\text { cultivation }\end{array}$ & Population & \multicolumn{2}{c}{ Average daily consumption per capita } \\
\hline & & & Ozs per head & $\begin{array}{c}\text { Calories per } \\
\text { head }\end{array}$ \\
\hline 1700 & 21,162 & $5,444,426$ & 2.29 & 52.57 \\
1750 & 36,050 & $6,192,091$ & 3.43 & 78.86 \\
1800 & 104,734 & $9,223,320$ & 6.69 & 153.98 \\
1850 & 337,776 & $17,928,000$ & 11.10 & 255.34 \\
\hline
\end{tabular}

Sources: Salaman (1949, p. 613) estimated the amount of land under cultivation, the population and average daily consumption in pounds for various years between 1775 and 1914. Floud et al. (2011, p. 221 ) assumed that consumption grew consistently between 1600 and 1775, between 1775 and 1814, and between 1838 and 1851 , and used the resulting figures to estimate average daily consumption, by weight and calories, in 1700, 1750, 1800 and 1850. The current table reproduces their figures for population, ounces per head and calories per head in these years. It also shows the implied figures for the amount of land under cultivation, assuming that each acre yielded 13,440 lbs of edible potato.

Floud et al. derived these estimates from Salaman's classic account of the history and social influence of the potato from its Andean origins. Although he argued that 'the potato reached [Britain] at the end of sixteenth century', he also suggested that there was little evidence of cultivation before 1770 (Salaman 1949, p. 
This article is (c) Emerald Group Publishing and permission has been granted for this version to appear here

(http://strathprints.strath.ac.uk/50435/). Emerald does not grant permission for this article to be further copied/distributed or hosted elsewhere without the express permission from Emerald Group Publishing Limited.

537). He derived his figures for 1775 and 1795 from contemporary accounts of the

consumption of potatoes in northern England at the end of the eighteenth century, and estimated the amount of land under cultivation in 1814 and 1838 from

contemporary Scottish figures. He then used James Caird's (1852) account of the total amount of land used for the cultivation of potatoes, turnips and mangolds to estimate a separate figure for potatoes in 1851. He also used the Board of Trade's official returns to estimate the extent of potato cultivation in 1866 and 1871 , and in 1881, 1891, 1901, 1911 and 1914. However, unlike Overton and Campbell, he included both English and Welsh figures, and he added a further 70,000 acres for allotments, gardens and small 'potato-patches' (Salaman, 1949, pp. 611-3).

This account raises two main issues. In the first place, as we have already seen, Salaman (1949, p. 537) argued that potato cultivation rose rapidly 'from a very small, though quite uncertain, initial acreage in 1770'. However, he also argued that it 'reached this country at the end of the sixteenth century' and made 'rapid progress in Lancashire and the north' (Salaman, 1949, pp. 434, 451). When Floud et al. (2011, p. 157) used these data, they allowed their figures for potato consumption to rise consistently from 1600 to 1775 . If Salaman was right to suggest that potatoes were grown on a very small number of acres before 1770 , this assumption may have led them to overestimate the number of calories derived from potatoes in both 1700 and 1750 .

The second question concerns the compatibility of Salaman's figures with those of later authors. The most direct point of comparison is with Turner's suggestion that between 0.157 and 0.173 million acres were devoted to the cultivation of potatoes in 1801 (Turner, 1981, pp. 296-7). By contrast, Salaman argued that only 0.1 million acres were devoted to potatoes in 1795 and that the figure of 0.16 million was not reached until 1814 (Salaman, 1949, p. 613). If we 
This article is (c) Emerald Group Publishing and permission has been granted for this version to appear here

(http://strathprints.strath.ac.uk/50435/). Emerald does not grant permission for this article to be further copied/distributed or hosted elsewhere without the express permission from Emerald Group Publishing Limited.

were to recalculate Floud et al.'s figures for 1800 using Turner's proposed acreage,

the number of calories supplied in this year would rise by between 77 and 102

$([157,138 \times 153.98] / 104,734=231.02 ;[174,423 \times 153.98] / 104,734=256.44)$.

Although Turner's figures for this period are clearly derived from a much more complete source of quantitative information than Salaman's, there are two potential problems. As we have already seen, Salaman (1949, p. 613) was explicit in stating that his figures were based on the amount of land devoted to the cultivation of potatoes for human consumption, but others have been less so. According to Holderness (1989, p. 144), a large proportion of the potatoes which were cultivated at the end of the eighteenth century were likely to have been consumed by animals, and this impression is reinforced by a number of contemporary accounts. Sir Archibald Grant (1766, p. 11) complained that 'potatoes are good for none but swine and those they won't fatten', and Arthur Young (1771a, p. 409) claimed that 'the object in cultivating potatoes is not Covent Garden but the food of cattle' (see also Bourke, 1993, p. 38). Salaman (1949, pp. 503-17) argued that the use of potatoes for human consumption increased rapidly at the end of the eighteenth century but the prejudice against them continued well into the nineteenth (see e.g. Burnett, 1979, p. 28). It may therefore be dangerous to infer the number of 'human' calories from contemporary estimates of the amount of land devoted to the cultivation of potatoes without taking some account of changing patterns of potato usage.

It is also important to consider the methods which Turner used to generate his figures. As he pointed out, none of his calculations took any account of the 'untold acres of potatoes' grown on small plots or gardens (Turner, 1981, p. 293). However, his method of calculation may have encouraged him to overestimate the amount of land devoted to the cultivation of potatoes on farms. As we have already 
This article is (c) Emerald Group Publishing and permission has been granted for this version to appear here

(http://strathprints.strath.ac.uk/50435/). Emerald does not grant permission for this article to be further copied/distributed or hosted elsewhere without the express permission from Emerald Group Publishing Limited.

noted, he developed these estimates by comparing the total amount of land

devoted to potatoes in the extant crop returns $(76,679$ acres) with the total amount of recorded arable acreage $(3,453,391$ acres). He then offered two alternative estimates of 'true' arable coverage (7,077,194 acres and 7,680,105 acres) and used the ratio of recorded potato acres to recorded arable acres to estimate total potato coverage. However, the coverage of the returns varied by county and some counties grew more potatoes than others. If we were to scale the figures up at the level of each county, rather than the country as a whole, the total amount of land devoted to potatoes would be somewhat lower. If the 'true' amount of arable land was 7,077,194 acres, the amount devoted to potatoes would have been 140,827; if the 'true' total was $7,860,105$, the amount devoted to potatoes would have been 156,406 . These figures are approximately ten per cent lower than the figures on which Overton and Campbell and Broadberry et al.'s estimates were based.

\subsection{Extraction rates}

In order to estimate the proportion of the total crop which became available for human consumption, it is necessary to make allowances for seeding, the consumption of grain by animals, processing, distribution and wastage. Floud et al. (2011, pp. 205-9) used data from the United States to estimate the proportion of cereals and pulses 'lost' as a result of seeding, animal consumption and processing, and allowed an extra ten per cent for wastage. They assumed that the gross extraction rate (the amount of food available for human consumption as a proportion of the gross yield of each crop) remained constant over the whole of the period from 1700 to 1850 .

These assumptions have not escaped criticism. Kelly and Ó Gráda (2013b, p. 2) argued that 'Floud et al.'s assumed proportions of wheat, barley and rye entering 
This article is (c) Emerald Group Publishing and permission has been granted for this version to appear here

(http://strathprints.strath.ac.uk/50435/). Emerald does not grant permission for this article to be further copied/distributed or hosted elsewhere without the express permission from Emerald Group Publishing Limited.

gross product ... seem to be on the low side' and that 'the assumed losses from

processing and distribution may be too high except, perhaps, in the case of barley'.

Meredith and Oxley (2014, p. 180) also thought that Floud et al.'s 'assumptions

regarding loss ... are arguably very high' although, as we shall see, this did not

prevent them from accepting the same rates when performing their final

calculations.

It is difficult to compare the impact of these assumptions directly with those made by Broadberry et al. because Broadberry and his co-authors only showed the proportion of the total crop which remained available for human consumption after making an initial allowance for seeding. However, we can address this for some crops using the figures on gross and net yields in Overton and Campbell's paper (1996, pp. $292-5 ; 2006$, pp. 37-44), and we can also compare their figures with those published by Austin Bourke (1993, pp. 162-3). These figures enable us to make separate calculations for the proportions of the original crop which were 'lost' in the form of seeds, animal consumption, wastage and processing for wheat, rye, barley and oats.

As we can see from Table 11, both Bourke (1993, pp. 159-63) and Overton and Campbell (1996, p. $294 ; 2006$, p. 41 ) attempted to estimate the proportion of the main cereal crops which were lost as a result of processing. Bourke derived his figures from a series of contemporary British and Irish estimates, whereas the origins of some of Overton and Campbell's figures are a little less clear. However, the initial estimates were actually very similar. Bourke estimated that the 'costs' of converting grain to meal were equal to 17 per cent of the original crop in the case of barley and 22 per cent in the case of rye, whereas Overton and Campbell used figures of 22 per cent and 20 per cent respectively, but the figures for wheat and oats were identical. However, Overton and Campbell included separate allowances 
This article is (c) Emerald Group Publishing and permission has been granted for this version to appear here

(http://strathprints.strath.ac.uk/50435/). Emerald does not grant permission for this article to be further copied/distributed or hosted elsewhere without the express permission from Emerald Group Publishing Limited.

for the proportions of the original crop used for seeding and animal consumption

and added a separate figure for wastage. They also introduced a separate

calculation based on the differences between barley and beer.

Table 11. Processing costs: Bourke versus Overton and Campbell

\begin{tabular}{|c|c|c|c|c|c|c|}
\hline & & \multicolumn{4}{|c|}{ Bourke } & $\begin{array}{l}\text { Overton \& } \\
\text { Campbell }\end{array}$ \\
\hline & & $\begin{array}{l}\text { Original } \\
\text { weight }\end{array}$ & Net weight & $\begin{array}{c}\text { Conversion } \\
\text { ratio }\end{array}$ & $\begin{array}{l}\text { mplied losses } \\
\text { associated } \\
\text { with } \\
\text { processing }\end{array}$ & $\begin{array}{l}\text { Losses due to } \\
\text { processing }\end{array}$ \\
\hline Wheat & & 140 & 112 & 0.80 & 0.20 & 0.20 \\
\hline Rye & & 144 & 112 & 0.78 & 0.22 & 0.20 \\
\hline Barley & $\begin{array}{l}\text { As bread } \\
\text { As beer }\end{array}$ & 135 & 112 & $\begin{array}{l}0.83 \\
- \\
\end{array}$ & $\begin{array}{l}0.17 \\
- \\
\end{array}$ & $\begin{array}{l}0.22 \\
0.70\end{array}$ \\
\hline Oats & & 200 & 112 & 0.56 & 0.44 & 0.44 \\
\hline
\end{tabular}

Sources: Bourke, 1993, pp. 162-3; Overton and Campbell, 1996, pp. 292-5; 2006, pp. 37-44.

The figures produced by Overton and Campbell are compared with those published by Floud et al. in Table 12. As we have already explained, Floud et al. assumed that the proportion of each crop which entered gross production remained constant throughout the period, as did the proportions lost through processing and wastage. Overton and Campbell suggested that the extraction rates of wheat and rye both increased between 1700 and 1830 . This was because the amount of grain which was used for seeding remained constant at 2.5 bushels per acre, with the result that the proportion fell as the total yield increased. Floud et al. also suggested that the extraction rates for these two crops were consistently lower than the figures suggested by Overton and Campbell throughout the period, but their figures for barley were greater, and their figures for oats became greater as the period progressed. When the extraction rates for all four crops are combined, Floud et al.'s figures are also lower, but not excessively so. Floud et al. estimated a combined extraction rate of between 30 and 33 per cent, whereas Overton and Campbell's figure was around 36 per cent. 
This article is (c) Emerald Group Publishing and permission has been granted for this version to appear here

(http://strathprints.strath.ac.uk/50435/). Emerald does not grant permission for this article to be further copied/distributed or hosted elsewhere without the express permission from Emerald Group Publishing Limited.

It is also possible to use these data to examine the effect of substituting

Overton and Campbell's extraction rates for Floud et al.'s rates, whilst leaving all other aspects of Floud et al.'s estimates unchanged. Table 13 suggests that the answer depends on the mixture of crops in Floud et al.'s tables. If we apply Overton and Campbell's figures to the combination of crops in Estimate A, average daily consumption rises by 56 calories in 1700 and 72 calories in both 1750 and 1800 , before falling in 1850 . If we apply their figures to the mixture of crops in Estimate B, average consumption rises by 99 calories in 1750 and 67 calories in 1800 , and falls by 32 calories in 1850 . If we were to apply these figures to the totals in Table 2, the effect would be to accentuate the differences between the two sets of Estimates. The application of Overton and Campbell's extraction rates to the figures in Estimate A would mean that consumption rose between 1700 and 1750 and again between 1750 and 1800 , before falling between 1800 and 1850 . If we were to apply their figures to Estimate $B$, total consumption would rise more sharply between 1700 and 1750 and fall between 1750 and 1800 , with little change over the next half-century. 
This article is $\odot$ Emerald Group Publishing and permission has been granted for this version to appear here (http://strathprints.strath.ac.uk/50435/). Emerald does not grant permission for this article to be further copied/distributed or hosted elsewhere without the express permission from Emerald Group Publishing Limited.

Table 12. Food extraction rates: Floud et al. versus Overton and Campbell

\begin{tabular}{|c|c|c|c|c|c|c|c|c|c|c|c|c|c|c|c|}
\hline & \multicolumn{12}{|c|}{ Overton and Campbell } & \multicolumn{3}{|c|}{ Floud et al. A } \\
\hline & & & & $\begin{array}{l}\text { Millions } \\
\text { of acres }\end{array}$ & $\begin{array}{l}\text { Gross } \\
\text { output } \\
\text { (tn } \\
\text { calories) } \\
\end{array}$ & $\begin{array}{c}\text { Total } \\
\text { output } \\
\text { (tn } \\
\text { calories, } \\
\text { net of } \\
\text { seed) } \\
\end{array}$ & $\begin{array}{l}\text { Proportion } \\
\text { fed to } \\
\text { livestock }\end{array}$ & $\begin{array}{c}\% \\
\text { entering } \\
\text { gross } \\
\text { product } \\
\end{array}$ & $\begin{array}{c}\text { Losses } \\
\text { due to } \\
\text { wastage }\end{array}$ & $\begin{array}{l}\text { Losses due } \\
\text { to } \\
\text { processing }\end{array}$ & $\begin{array}{l}\text { Proportion } \\
\text { net of } \\
\text { milling and } \\
\text { distribution } \\
\text { losses }\end{array}$ & $\begin{array}{c}\text { Gross } \\
\text { extraction rate } \\
\text { (including } \\
\text { allowance for } \\
\text { seed) }\end{array}$ & $\begin{array}{c}\% \\
\text { entering } \\
\text { gross } \\
\text { product } \\
\end{array}$ & $\begin{array}{l}\text { Proportion } \\
\text { net of } \\
\text { milling and } \\
\text { distribution }\end{array}$ & $\begin{array}{c}\text { Gross } \\
\text { extraction } \\
\text { rate } \\
\text { (including } \\
\text { allowance } \\
\text { for seed) } \\
\end{array}$ \\
\hline & & & $\begin{array}{c}\text { O \& C, } \\
\text { Tab. } \\
12\end{array}$ & $\begin{array}{l}\text { O \& C, } \\
\text { Tab. } 5\end{array}$ & $\begin{array}{c}\text { O \& C, } \\
\text { Tabs. } 5 \& \\
9\end{array}$ & $\begin{array}{c}\text { O \& C } \\
\text { Tabs. } 5 \\
\& 9\end{array}$ & $\begin{array}{l}\text { O \& C, } \\
\text { Tab. } 12\end{array}$ & & & & & & & & \\
\hline \multirow[t]{7}{*}{1700} & Wheat & & - & 1.60 & 2.22 & 1.87 & 0.020 & 0.825 & 0.10 & 0.20 & 0.70 & 0.5774 & 0.855 & 0.6189 & 0.5292 \\
\hline & Rye & & - & 0.52 & 0.57 & 0.46 & 0.000 & 0.807 & 0.10 & 0.20 & 0.70 & 0.5651 & 0.737 & 0.5345 & 0.3939 \\
\hline & Barley & As bread & 0.30 & - & - & - & - & - & 0.10 & 0.22 & 0.68 & & - & - & - \\
\hline & Barley & Brewed & 0.68 & - & - & - & - & - & 0.10 & 0.70 & 0.20 & & - & - & - \\
\hline & Barley & & - & 2.04 & 2.61 & 2.04 & 0.020 & 0.766 & 0.10 & 0.55 & 0.35 & 0.2656 & 0.850 & 0.4000 & 0.3400 \\
\hline & Oats & & - & 1.06 & 1.48 & 1.22 & 0.600 & 0.329 & 0.10 & 0.44 & 0.46 & 0.1511 & 0.280 & 0.4263 & 0.1194 \\
\hline & Total & & - & 5.22 & 6.89 & 5.59 & 0.143 & 0.694 & & & & 0.3663 & 0.701 & 0.4733 & 0.3318 \\
\hline \multirow[t]{7}{*}{1750} & Wheat & & - & - & - & - & - & - & - & - & - & - & 0.855 & 0.6189 & 0.5292 \\
\hline & Rye & & - & - & - & - & - & - & - & - & - & - & 0.737 & 0.5345 & 0.3939 \\
\hline & Barley & As bread & - & - & - & - & - & - & - & - & - & - & - & - & - \\
\hline & Barley & Brewed & - & - & - & - & - & - & - & - & - & - & - & - & - \\
\hline & Barley & & - & - & - & - & - & - & - & - & - & - & 0.850 & 0.4000 & 0.3400 \\
\hline & Oats & & - & - & & - & - & - & - & - & - & - & 0.280 & 0.4263 & 0.1194 \\
\hline & Total & & - & - & - & - & - & - & - & - & - & - & 0.627 & 0.4799 & 0.3009 \\
\hline \multirow[t]{7}{*}{1800} & Wheat & & - & 2.44 & 4.66 & 4.12 & 0.020 & 0.867 & 0.10 & 0.20 & 0.70 & 0.6070 & 0.855 & 0.6189 & 0.5292 \\
\hline & Rye & & - & 0.06 & 0.11 & 0.10 & 0.000 & 0.886 & 0.10 & 0.20 & 0.70 & 0.6201 & 0.737 & 0.5345 & 0.3939 \\
\hline & Barley & As bread & 0.20 & - & - & - & - & - & 0.10 & 0.22 & 0.68 & - & - & - & - \\
\hline & Barley & Brewed & 0.78 & - & - & - & - & - & 0.10 & 0.70 & 0.20 & - & - & - & - \\
\hline & Barley & & - & 1.38 & 2.84 & 2.46 & 0.020 & 0.847 & 0.10 & 0.60 & 0.30 & 0.2523 & 0.850 & 0.4000 & 0.3400 \\
\hline & Oats & & - & 1.93 & 3.94 & 3.44 & 0.700 & 0.262 & 0.10 & 0.44 & 0.46 & 0.1204 & 0.280 & 0.4263 & 0.1194 \\
\hline & Total & & - & 5.81 & 11.55 & 10.11 & 0.252 & 0.656 & & & & 0.3540 & 0.638 & 0.4930 & 0.3145 \\
\hline \multirow[t]{4}{*}{1830} & Wheat & & - & 3.40 & 6.39 & 5.64 & 0.020 & 0.865 & 0.10 & 0.20 & 0.70 & 0.6057 & - & - & - \\
\hline & Rye & & - & 0.06 & 0.11 & 0.10 & 0.000 & 0.886 & 0.10 & 0.20 & 0.70 & 0.6201 & - & - & - \\
\hline & Barley & As bread & 0.10 & - & - & - & - & - & 0.10 & 0.22 & 0.68 & - & - & - & - \\
\hline & Barley & Brewed & 0.86 & - & - & - & & - & 0.10 & 0.70 & 0.20 & . & - & - & - \\
\hline
\end{tabular}

Forthcoming in Research in Economic History, 31 (2015) 
This article is $\odot$ Emerald Group Publishing and permission has been granted for this version to appear here (http://strathprints.strath.ac.uk/50435/). Emerald does not grant permission for this article to be further copied/distributed or hosted elsewhere without the express permission from Emerald Group Publishing Limited.

\begin{tabular}{|c|c|c|c|c|c|c|c|c|c|c|c|c|c|c|c|}
\hline & Barley & & - & 2.00 & 4.36 & 3.80 & 0.040 & 0.837 & 0.10 & 0.65 & 0.25 & 0.2092 & - & - & - \\
\hline & Oats & & - & 1.60 & 3.44 & 3.02 & 0.800 & 0.176 & 0.10 & 0.44 & 0.46 & 0.0809 & - & - & - \\
\hline & Total & & - & 7.06 & 14.30 & 12.57 & 0.214 & 0.691 & - & - & - & 0.3587 & - & - & - \\
\hline \multirow[t]{7}{*}{1850} & Wheat & & - & - & - & - & - & - & - & - & - & - & 0.855 & 0.6189 & 0.5292 \\
\hline & Rye & & - & - & - & - & - & - & - & - & - & - & 0.737 & 0.5345 & 0.3939 \\
\hline & Barley & As bread & - & - & - & - & - & - & - & - & - & - & - & - & - \\
\hline & Barley & Brewed & - & - & - & - & - & - & - & - & - & - & - & - & - \\
\hline & Barley & & - & - & - & - & - & - & - & - & - & - & 0.850 & 0.4000 & 0.3400 \\
\hline & Oats & & - & - & - & - & - & - & - & - & - & - & 0.280 & 0.4263 & 0.1194 \\
\hline & Total & & - & - & - & - & - & - & - & - & - & - & 0.651 & 0.4973 & 0.3236 \\
\hline \multirow[t]{7}{*}{1871} & Wheat & - & - & 3.32 & 8.57 & 7.80 & 0.020 & 0.893 & 0.10 & 0.20 & 0.70 & 0.6248 & - & - & - \\
\hline & Rye & - & - & 0.06 & 0.11 & 0.10 & 0.000 & 0.886 & 0.10 & 0.20 & 0.70 & 0.6201 & - & - & - \\
\hline & Barley & As bread & 0.00 & - & - & - & - & - & 0.10 & 0.22 & 0.68 & - & - & - & - \\
\hline & Barley & Brewed & 0.95 & - & - & - & - & - & 0.10 & 0.70 & 0.20 & - & - & - & - \\
\hline & Barley & - & - & 1.96 & 4.84 & 4.27 & 0.050 & 0.838 & 0.10 & 0.70 & 0.20 & 0.1677 & - & - & - \\
\hline & Oats & - & - & 1.45 & 4.03 & 3.65 & 0.900 & 0.091 & 0.10 & 0.44 & 0.46 & 0.0417 & - & - & - \\
\hline & Total & - & - & 6.79 & 17.55 & 15.83 & 0.230 & 0.693 & & & & 0.3647 & - & - & - \\
\hline
\end{tabular}

Notes. Overton and Campbell (1996, p. 294; 2006, p. 41) did not include estimates of the gross and net numbers of calories from rye in 1871 . However, their estimates for the amount of land under cultivation were the same as for 1800 and 1830 . Changes in the 'total' extraction rate for Floud et al. reflect changes in the proportion of land under cultivation for each crop and in the gross yields per crop. The 'total' figures for Floud et al.'s Estimate B would therefore be as follows: 1750: 0.2909; 1800: 0.3072; 1850: 0.3120.

Sources: Overton and Campbell, 1996, pp. 292-5; 2006, pp. 37-44; Floud et al. 201 1, pp. 205-9. 
This article is $\odot$ Emerald Group Publishing and permission has been granted for this version to appear here (http://strathprints.strath.ac.uk/50435/). Emerald does not grant permission for this article to be further copied/distributed or hosted elsewhere without the express permission from Emerald Group Publishing Limited.

Table 13. Differences between estimates, using Broadberry et al.'s extraction rates

\begin{tabular}{|c|c|c|c|c|c|c|c|c|c|c|}
\hline & & \multirow[t]{2}{*}{ Crop } & \multicolumn{4}{|c|}{ Floud et al. A (Calories per person per day) } & \multicolumn{4}{|c|}{ Floud et al. B (Calories per person per day) } \\
\hline & & & 1700 & 1750 & 1800 & 1850 & 1700 & 1750 & 1800 & 1850 \\
\hline (1) & Original conversion rates & Wheat & 502.43 & 657.28 & 732.04 & 706.28 & 502.43 & 804.29 & 717.77 & 729.03 \\
\hline (2) & Original conversion rates & Rye & 250.76 & 131.15 & 76.31 & 14.09 & 250.76 & 131.15 & 68.75 & 14.01 \\
\hline (3) & Original conversion rates & Barley & 598.22 & 421.05 & 314.98 & 227.49 & 598.22 & 417.67 & 306.75 & 226.80 \\
\hline (4) & Original conversion rates & Oats & 122.19 & 204.98 & 172.02 & 101.14 & 122.19 & 269.00 & 183.94 & 119.88 \\
\hline (5) & Original conversion rates & Total & 1473.60 & 1414.46 & 1295.35 & 1049.00 & 1473.60 & 1622.11 & 1277.21 & 1089.72 \\
\hline (6) & Broadberry et al.'s conversion rates) & Wheat & 548.19 & 735.53 & 839.66 & 820.81 & 548.19 & 900.04 & 823.29 & 847.25 \\
\hline (7) & Broadberry et al.'s conversion rates) & Rye & 359.69 & 197.28 & 120.11 & 22.18 & 359.69 & 197.28 & 108.22 & 22.05 \\
\hline (8) & Broadberry et al.'s conversion rates) & Barley & 467.31 & 320.68 & 233.73 & 126.43 & 467.31 & 318.10 & 227.63 & 126.05 \\
\hline (9) & Broadberry et al.'s conversion rates) & Oats & 154.69 & 233.13 & 173.52 & 52.35 & 154.69 & 305.95 & 185.54 & 62.05 \\
\hline (10) & Broadberry et al.'s conversion rates) & Total & 1529.88 & 1486.62 & 1367.02 & 1021.77 & 1529.88 & 1721.37 & 1344.68 & 1057.40 \\
\hline (11) & Difference between (5) and (10) & & 56.28 & 72.16 & 71.67 & $(27.23)$ & 56.28 & 99.26 & 67.47 & $(32.32)$ \\
\hline
\end{tabular}

Sources: See Table 12. 
This article is (C) Emerald Group Publishing and permission has been granted for this version to appear here

(http://strathprints.strath.ac.uk/50435/). Emerald does not grant permission for this article to be further copied/distributed or hosted elsewhere without the express permission from Emerald Group Publishing Limited.

\subsection{Meat and dairy products}

Floud et al. and Broadberry et al. derived their estimates of the numbers of calories from meat and dairy products from different sources. Broadberry et al. derived their information from studies by John (1989, pp. 1042-6), Clark (1991, p. 216) and Allen (2005, pp. 29, 33). Floud et al. drew their information from King (1696, pp. 54-5) and Holderness (1989, pp. 155, 170). They also sought to estimate the number of calories derived from lard with information from US sources (Bennett and Pierce, 1961, pp. 114-5).

Although meat and dairy products only accounted for a minority of total calories between 1700 and 1850 , the differences between the two sets of estimates are noticeable. Broadberry et al. (2011, p. 59; forthcoming, Table 8.7) increased the total value of 'non-arable' foods by adding 200 calories per person per day for fish and poultry, whereas Floud et al. (2011, p. 156) only allowed 24 extra calories from fish and made no allowances for poultry, game or rabbits before the twentieth century. However, Broadberry et al.'s other estimates were much lower. They suggested that the number of calories derived from beef, mutton, pork and dairy products accounted for no more than 380 calories per day between 1700/09 and 1850/59, whereas Floud et al.'s estimates ranged from 538 calories to 786 . 
Table 14. Meat and dairy products: Broadberry et al. versus Floud et al.

\begin{tabular}{|c|c|c|c|c|c|c|c|c|c|c|}
\hline & \multicolumn{5}{|c|}{ Broadberry et al. } & \multicolumn{5}{|c|}{ Floud et al. } \\
\hline & $\begin{array}{c}\text { Calories per } \\
\text { unit }\end{array}$ & $1700 / 09$ & $1750 / 59$ & $1800 / 09$ & $1850 / 59$ & $\begin{array}{c}\text { Calories per } \\
\text { unit }\end{array}$ & 1700 & 1750 & 1800 & 1850 \\
\hline & (1) & (2) & (3) & (4) & (5) & (6) & (7) & (8) & (9) & (10) \\
\hline Milk (gallon) & 3,185 & 25.58 & 59.33 & 52.56 & 76.52 & 3,256 & - & 87.23 & 52.34 & 90.14 \\
\hline Cheese (Ib) & 1,032 & 13.81 & 33.20 & 39.37 & 26.40 & 1,757 & - & 78.46 & 70.62 & 51.79 \\
\hline Butter (lb) & 2,270 & 21.27 & 51.63 & 66.89 & 41.90 & 3,612 & - & 112.89 & 112.89 & 77.41 \\
\hline All dairy & - & 60.66 & 144.16 & 158.82 & 144.83 & - & 230.75 & 278.58 & 235.84 & 219.33 \\
\hline Beef (lb) & 1,035 & 16.91 & 23.70 & 35.77 & 31.93 & - & - & - & - & - \\
\hline Veal (lb) & 681 & 1.93 & 2.60 & 3.76 & 3.08 & - & - & - & - & - \\
\hline Beef and veal (lb) & - & 18.84 & 26.30 & 39.53 & 35.01 & 1,318 & 137.97 & 166.57 & 143.32 & 121.38 \\
\hline Mutton (Ib) & 1,039 & 101.96 & 111.28 & 130.17 & 99.28 & 1,472 & 75.86 & 141.53 & 137.90 & 105.32 \\
\hline Pork (lb) & 1,003 & 25.50 & 34.93 & 50.82 & 44.51 & - & - & - & - & - \\
\hline Pork and ham (lb) & - & - & - & - & - & 2,041 & 61.42 & 146.65 & 128.37 & 89.08 \\
\hline Lard & - & - & - & - & - & 4,040 & 21.99 & 52.50 & 45.70 & 31.89 \\
\hline Others & - & - & - & - & - & 1,215 & 9.65 & - & - & - \\
\hline Total meat and dairy & - & 206.97 & 316.66 & 379.34 & 323.63 & - & 537.64 & 785.83 & 691.13 & 567.00 \\
\hline
\end{tabular}

Notes. In column 1, the figure for veal is from Bennett and Pierce 1961: 116-7; all other figures are from Broadberry et al., forthcoming, Table 8.5. In columns 2-5, figures for milk, cheese and butter are derived from Broadberry et al., forthcoming: Table 8.6; all other figures have been calculated from the figures in Broadberry et al. 2011 : Tables 7 and 23. The figures in the final row of columns 2-5 differ from Broadberry et al.'s published figures because they use information from a different source to calculate the number of calories derived from veal and because they combine data from Broadberry et al.'s two publications. The published totals are as follows: Broadberry et al. 201 1: 1700/09: 236; 1750/59: 292; 1800/09: 379; 1850/59: 328; Broadberry et al., forthcoming: 1700/09: 210; 1750/59: 319; 1800/09: 385; 1850/59: 328.

Sources: Col. 1: Broadberry et al., forthcoming, Table 8.5; Bennett and Pierce, 1961, pp. 116-7; Cols. 2-5: Broadberry et al., 201 1, Table 7; Broadberry et al., forthcoming, Table 8.6; Cols. 6-10: Floud et al., 2011, pp. 210-11. 
This article is $\odot$ Emerald Group Publishing and permission has been granted for this version to appear here (http://strathprints.strath.ac.uk/50435/). Emerald does not grant permission for this article to be further copied/distributed or hosted elsewhere without the express permission from Emerald Group Publishing Limited.

Table 15. Numbers of animals and their yields: Allen versus Broadberry et al.

Allen 2005

Broadberry et al. 201

\begin{tabular}{|c|c|c|c|c|c|c|c|c|c|c|c|c|c|c|c|c|}
\hline & \multicolumn{4}{|c|}{ Millions of animals } & \multicolumn{4}{|c|}{ Gallons or pounds per animal } & \multicolumn{4}{|c|}{$\begin{array}{c}\text { Numbers of non-working animals in } \\
\text { England (millions) }\end{array}$} & \multicolumn{4}{|c|}{ English yields per animal } \\
\hline & 1700 & 1750 & 1800 & 1850 & 1700 & 1750 & 1800 & 1850 & $1700 / 09$ & $1750 / 59$ & $1800 / 09$ & $1850 / 59$ & $1700 / 09$ & $1750 / 59$ & $1800 / 09$ & $1850 / 59$ \\
\hline Cows & 1.55 & 1.55 & 1.21 & 1.44 & 300 & 330 & 380 & 440 & 0.36 & 0.46 & 0.83 & 1.15 & 272.01 & 316.69 & 368.72 & 429.29 \\
\hline Calves/veal & 1.55 & 1.55 & 1.21 & 1.44 & 39 & 45 & 75 & 105 & 0.36 & 0.46 & 0.83 & 1.15 & 67.12 & 76.84 & 87.96 & 100.69 \\
\hline Beef cattle & 1.40 & 1.40 & 1.09 & 1.30 & 260 & 400 & 500 & 700 & 0.32 & 0.42 & 0.75 & 1.04 & 384.98 & 440.22 & 503.37 & 575.59 \\
\hline Total cattle & 4.50 & 4.50 & 3.51 & 4.18 & 198 & 254 & 312 & 405 & 1.04 & 1.34 & 2.41 & 3.34 & 235.85 & 273.07 & 313.93 & 361.70 \\
\hline Sheep & 16.60 & 16.60 & 20.00 & 26.70 & 30 & 52 & 60 & 70 & 15.40 & 14.86 & 19.82 & 22.62 & 46.39 & 52.53 & 59.49 & 67.36 \\
\hline Hogs/swine & 1.30 & 1.70 & 1.90 & 2.30 & 64 & 95 & 110 & 125 & 0.95 & 1.10 & 1.75 & 2.20 & 86.56 & 98.78 & 112.72 & 128.63 \\
\hline
\end{tabular}

Notes. The notes to Broadberry et al.'s table also refer to estimates published by A.H. John (1989, pp. 1042-6). He proposed the following figures for the numbers of different types of animal in 1770 and 1854: 1770: cows: 0.74 million; young cattle: 0.91 million; fatting cattle: 0.51 million; sheep: 22.19 million; swine: 1.71 million; 1854 : milch cows: 1.38 million; calves: 0.71 million; other cattle: 1.34 million; sheep: 12.12 million; swine: 2.36 million. As with Allen's figures, these estimates refer to the whole of England and Wales.

Sources: John, 1989, pp. 1042-6; Allen, 2005, pp. 29, 33; Broadberry et al., 2011, pp. 41-2. 
This article is (c) Emerald Group Publishing and permission has been granted for this version to appear here

(http://strathprints.strath.ac.uk/50435/). Emerald does not grant permission for this article to be further copied/distributed or hosted elsewhere without the express permission from Emerald Group Publishing Limited.

There appear to be two main reasons for these differences. In the first place,

Broadberry et al. used much lower calorific values to estimate the amount of energy derived from pork, cheese and butter. As we can see from Table 16, much of the difference between their estimates of the number of calories derived from these sources and Floud et al.'s estimates can be attributed to this cause. The second source of variation is the amount of meat derived from cattle, but the ultimate cause of this difference is unclear. Broadberry et al. suggest that they derived their estimates of the numbers of animals from Allen (2005) and John (1989, pp. 1042-6), but their figures are much closer to the latter (see Table 17). This may help to explain why their overall estimates are so much lower than the figures which Allen himself proposed (Appendix 1).

\subsection{Imports and exports}

Of the various authors whose work has been considered in this paper, only Overton and Campbell (1996, p. 45; 2006, p. 296, Allen (2005, p. 39), Broadberry et al. (2011, p. 59; forthcoming: Table 8.7) and Floud et al. (2011) framed their own estimates of the number of calories derived from imported foodstuffs. Meredith and Oxley (2014, pp. 169-70) made no allowance for imports or exports in 1770, but used Floud et al.'s figures for 1700, 1800 and 1850. However, Floud et al. were the only authors who attempted to go beyond the production of estimates for arable, meat and dairy products, and only Floud et al. and Broadberry et al. provided much information about the sources of their figures. Broadberry et al. (forthcoming: section 8.2.1) derived their figures from those published by Mitchell (1988), whereas Floud et al. derived their figures for 1800 and 1850 from the Parliamentary Papers (see Floud et al., 2011, pp. 212-19 for further details). However, although this enabled them to supplement Mitchell's figures with imports 
This article is (c) Emerald Group Publishing and permission has been granted for this version to appear here

(http://strathprints.strath.ac.uk/50435/). Emerald does not grant permission for this article to be further copied/distributed or hosted elsewhere without the express permission from Emerald Group Publishing Limited.

of other cereals and pulses (including maize, rye, peas, beans, buckwheat, beer or

bigg and malt) their calorie totals were lower. This may have been because they applied the same allowances for losses due to milling and distribution as they applied to domestic cereals.

Overall, Broadberry et al.'s estimates differ from those published by Floud et al. in two important respects (see Table 18). In the first place, they argued that the calorific value of imported grain products increased steadily from the $1750 \mathrm{~s}$ onwards. Floud et al. argued that Britain was a net exporter of grain calories in 1700 and 1750 , and - as we have already noted - they believed that the calorific value of imported grains in 1800 and 1850 was below the level suggested by Broadberry et al. for $1800 / 09$ and $1850 / 59$. The second major difference arises from the fact that Floud et al. also estimated the calorific value of other imported foods. Broadberry et al. (forthcoming, Table 8.10) acknowledged the importance of sugar and other imported items when they discussed the per capita consumption of imported luxury foodstuffs (including tobacco) but failed to incorporate these figures in their estimation of food values. 
This article is $\odot$ Emerald Group Publishing and permission has been granted for this version to appear here (http://strathprints.strath.ac.uk/50435/). Emerald does not grant permission for this article to be further copied/distributed or hosted elsewhere without the express permission from Emerald Group Publishing Limited.

Table 16. Calories from imported foodstuffs: Broadberry et al. versus Floud et al.

\begin{tabular}{|c|c|c|c|c|c|c|c|c|c|c|}
\hline & \multicolumn{3}{|c|}{ Broadberry et al. } & \multicolumn{7}{|c|}{ Floud et al. } \\
\hline & Grain & Meat & Total & $\begin{array}{c}\text { Cereals and } \\
\text { pulses }\end{array}$ & Meat & Dairy & $\begin{array}{c}\text { Fruit and } \\
\text { nuts }\end{array}$ & Sugar & $\begin{array}{c}\text { Wine and } \\
\text { spirits }\end{array}$ & Tota \\
\hline $1700(1700 / 09)$ & 0 & 0 & 0 & -13 & 0 & 0 & 0 & 28 & 12 & 27 \\
\hline $1750(1750 / 59)$ & 20 & 0 & 20 & -168 & 0 & 0 & 0 & 72 & 11 & -85 \\
\hline $1800(1800 / 09)$ & 168 & 0 & 168 & 86 & 0 & 16 & 0 & 95 & 17 & 214 \\
\hline $1850(1850 / 59)$ & 524 & 10 & 534 & 366 & 12 & 20 & 9 & 136 & 12 & 555 \\
\hline
\end{tabular}

Notes: The figures attributed to Broadberry et al. for grain imports in 1800/09 and 1850/59 differ slightly from those published in 2011 . Their earlier figures (Broadberry et al. 2011: 59) were as follows: 1800/09: grain imports: 166 calories; 1850/59: grain imports: 537 calories.

Sources: Broadberry et al., 201 1, p. 59; forthcoming, Table 8.7; Floud et al., 2011 , p. 159. 


\section{Irish imports}

Although Floud et al. considered the impact of foreign imports, they failed to examine the effect of trade from either Scotland or, more importantly, Ireland. Both Kelly and Ó Gráda (2013a; 2013b) and Meredith and Oxley (2014) have suggested that this omission could be significant. According to Meredith and Oxley (2014, p. 172), 'Scotland, Wales and especially Ireland were key suppliers: as early as the 1750 s and 1760 s, beef imports from Ireland trebled, and there were big increases in butter and pork'.2 Kelly and Ó Gráda (2013a, p. 1154) argued that 'allowing for imports of Irish meat and butter and ... Scottish cattle would increase Broadberry et al.'s total by a further $60 / 75$ kcals in 1800 and by perhaps $20 / 25$ kcals in 1750 '. They also suggested that the inclusion of Irish grain imports would have 'accounted for about 100 kilocalories daily per head in 1850 and perhaps double that before the Great Famine' (Kelly and Ó Gráda, 2013a, p. 1155).

In 1666, the English government banned the importation of Irish cattle, sheep, beef, butter and pork, and these restrictions remained in place for almost a century (Thomas, 1982, p. 334; 1985, p. $141 ; 1993$, pp. 86-7). However, the value of Irish meat and dairy imports increased substantially following the removal of these restrictions in 1758 and the value of grain imports increased from the $1770 \mathrm{~s}$ (Cullen, 1968, p. 49). Ralph Davis (1979, pp. 110-19) estimated that the cash value of imported Irish corn, meat and butter increased from $£ 934,000$ in the mid-1780s

\footnotetext{
As this paper is concerned with average consumption across the whole of England and Wales, we have not attempted to analyse the effects of trade within England and Wales, although we recognise that consumption patterns must have varied (see e.g. Collins, 1975). The question of Scotland is more complex. In the first place, as Smith $(1955$, p. 116) pointed out, many of the animals which might have been exported from Scotland had previously been imported from Ireland. Second, the amount of available data appears to be very limited. Sinclair (1814, p. 12) estimated that approximately 100,000 cattle were exported from Scotland to England in 1800, and Blackman (1975, p. 6) suggested that the trade peaked during the 1830 s, but more precise data for 1700,1750 and 1800 are lacking. If we assume that each animal weighed 600lbs, Sinclair's estimate would imply that Scottish cattle supplied just over 23 calories per head in $1800([100,000 \times 600 \times 1318.18] /[9,223,320 \times 365]=23.49)$, but we would still be lacking figures for other years.
} 
This article is (c) Emerald Group Publishing and permission has been granted for this version to appear here

(http://strathprints.strath.ac.uk/50435/). Emerald does not grant permission for this article to be further copied/distributed or hosted elsewhere without the express permission from Emerald Group Publishing Limited.

to just under $£ 5.6$ million in the mid-1820s. However, these figures tell us little

about the different types of grain or meat, and the British government stopped

recording non-grain imports from Ireland from 1827 onwards (Porter, 1851, p. 344).

As a result, the figures are an imperfect guide to overall trends in the nutritional

value of Irish food imports over the course of this period.

Table 17. Value (in f000) of Irish food exports to Britain, 1784/6-1824/6.

\begin{tabular}{|c|c|c|c|c|c|}
\hline & & \multicolumn{2}{|c|}{ Imports $(£ 000)$} & \multicolumn{2}{|c|}{ Imports (\%) } \\
\hline & & Ireland & Total & Ireland & Total \\
\hline $1784-86$ & Corn & 224 & 758 & 29.55 & 100.00 \\
\hline $1784-86$ & Meat & 324 & 325 & 99.69 & 100.00 \\
\hline $1784-86$ & Butter & 386 & 389 & 99.23 & 100.00 \\
\hline $1784-86$ & Total & 934 & 1,472 & 63.45 & 100.00 \\
\hline $1784-86$ & Other foodstuffs & 18 & 8,137 & 0.22 & 100.00 \\
\hline $1784-86$ & Grand Total & 952 & 9,609 & 9.91 & 100.00 \\
\hline $1794-96$ & Corn & 399 & 2,412 & 16.54 & 100.00 \\
\hline $1794-96$ & Meat & 706 & 720 & 98.06 & 100.00 \\
\hline $1794-96$ & Butter & 545 & 626 & 87.06 & 100.00 \\
\hline $1794-96$ & Total & 1,650 & 3,758 & 43.91 & 100.00 \\
\hline $1794-96$ & Other foodstuffs & 42 & 14,454 & 0.29 & 100.00 \\
\hline $1794-96$ & Grand Total & 1,692 & 18,212 & 9.29 & 100.00 \\
\hline $1804-86$ & Corn & 678 & 2,905 & 23.34 & 100.00 \\
\hline $1804-86$ & Meat & 922 & 991 & 93.04 & 100.00 \\
\hline $1804-86$ & Butter & 696 & 973 & 71.53 & 100.00 \\
\hline $1804-86$ & Total & 2,296 & 4,869 & 47.16 & 100.00 \\
\hline $1804-86$ & Other foodstuffs & 213 & 19,084 & 1.12 & 100.00 \\
\hline $1804-86$ & Grand Total & 2,509 & 23,953 & 10.47 & 100.00 \\
\hline $1814-16$ & Corn & 1,799 & 3,158 & 56.97 & 100.00 \\
\hline $1814-16$ & Meat & 1,318 & 1,363 & 96.70 & 100.00 \\
\hline $1814-16$ & Butter & 1,038 & 1,348 & 77.00 & 100.00 \\
\hline $1814-16$ & Total & 4,155 & 5,869 & 70.80 & 100.00 \\
\hline $1814-16$ & Other foodstuffs & 261 & 26,149 & 1.00 & 100.00 \\
\hline $1814-16$ & Grand Total & 4,416 & 32,018 & 13.79 & 100.00 \\
\hline $1824-26$ & Corn & 2,914 & 4,158 & 70.08 & 100.00 \\
\hline $1824-26$ & Meat & 1,677 & 1,777 & 94.37 & 100.00 \\
\hline $1824-26$ & Butter & 1,008 & 1,510 & 66.75 & 100.00 \\
\hline $1824-26$ & Total & 5,599 & 7,445 & 75.20 & 100.00 \\
\hline $1824-26$ & Other foodstuffs & 208 & 18,925 & 1.10 & 100.00 \\
\hline $1824-26$ & Grand Total & 5,807 & 26,370 & 22.02 & 100.00 \\
\hline All years & Corn & 6,014 & 13,391 & 44.91 & 100.00 \\
\hline All years & Meat & 4,947 & 5,176 & 95.58 & 100.00 \\
\hline All years & Butter & 3,673 & 4,846 & 75.79 & 100.00 \\
\hline All years & Total & 14,634 & 23,413 & 62.50 & 100.00 \\
\hline All years & Other foodstuffs & 742 & 86,749 & 0.86 & 100.00 \\
\hline All years & Grand Total & 15,376 & 110,162 & 13.96 & 100.00 \\
\hline
\end{tabular}

Source: Davis, 1979, pp. 110-19. 
This article is (c) Emerald Group Publishing and permission has been granted for this version to appear here

(http://strathprints.strath.ac.uk/50435/). Emerald does not grant permission for this article to be further copied/distributed or hosted elsewhere without the express permission from Emerald Group Publishing Limited.

\subsection{Irish grain exports}

It is possible to obtain more detailed information about the variety and quantity of grain and cereals imported from Ireland from a variety of sources. Information covering the importation of wheat and flour, barley and bigg, oats and oatmeal, rye, peas, beans and malt was published in the Parliamentary Papers on a number of occasions, including 1843 and 1852 (Parliamentary Papers, 1843, 1852), and additional information was published by the Secretary to the Board of Trade, John Macgregor, in 1850 (Macgregor, 1850, p. 168). Similar data were published by G.R. Porter (1851, p. 345), ${ }^{3}$ W.F. Galpin (1925, p. 252) and A.H. John (1989, p. 1018-20). John also published separate tables showing the importation of wheat and other crops into England and Wales in 1756/7 and from 1769-77, and into Great Britain from 1792 to 1850 . These statistics can be supplemented with more detailed information from the surviving Customs ledgers for the years 1792, 1800, 1806-7, $1812,1814-25$, and 1830-49 and can be converted into calories per head using the methods which Floud et al. used to estimate the calorific value of cereals and pulses imported from the rest of the world (Floud et al., 2011, pp. 212-16).

The following tables therefore enable us to build up a more detailed picture of the nutritional value of Irish grain imports over the course of this period. Tables 18 and 19 show the quantities of grain and meal imported in different years between 1756 and 1849. Table 20 uses these data to estimate the impact of these items on daily calorie intakes. Although the initial contribution appears to have been rather limited, our figures suggest that the average consumer may have derived almost 50

Both Donnelly (1975, p. 82) and Thomas (1985, p. 145; 1993, p. 91) described Porter's figures as 'inaccurate' without specifying the exact nature of their inaccuracy. Although Porter (1851, p. 345) failed to supply a source, many of his figures were identical to the figures published by Macgregor (1850, p. 168) and in the Parliamentary Papers $(1843 ; 1852)$, and most of the remaining figures were very similar. However, he provided significantly lower values for the importation of wheat and oats in 1832, and a significantly higher value for the importation of wheat in 1846. 
This article is (c) Emerald Group Publishing and permission has been granted for this version to appear here

(http://strathprints.strath.ac.uk/50435/). Emerald does not grant permission for this article to be further copied/distributed or hosted elsewhere without the express permission from Emerald Group Publishing Limited.

calories per day from Irish grain imports by 1792 . However the number of calories

declined during the remainder of the decade and fell dramatically during the early

years of the Napoleonic War, before recovering. It then rose substantially after

1815 and reached a peak of 183 calories per head at the end of the 1830 s. The

calorific value of Irish grain imports fluctuated during the first half of the $1840 \mathrm{~s}$

before declining dramatically during the Famine years.

These figures suggest that, over the period as a whole, Irish grain imports did indeed make a substantial contribution to the British diet but a focus on individual years, such as 1800 , could be misleading. As a result, when adding these data to our existing information for this year, it may be more appropriate to use the results for 1799. The interpretation of the figures for 1850 is more complex. In the first place, although data do exist for this year, they do not distinguish between grain and flour; and, second, even the published data suggest that the volume of imports had still not regained pre-Famine levels (see Parliamentary Papers, 1852). We have therefore decided to use the data for 1849 , but with the caveat that these data do underestimate the extent of Ireland's contribution in previous years. ${ }^{4}$

Having said this, it should also be noted that there was a substantial increase in the volume of non-Irish food imports from overseas during the 1840s. Net imports of wheat, flour, barley and oats more than doubled between 1840 and 1849 (Mitchell, 1988, p. 225). 
Table 18. Irish exports of grain and meal (in quarters) to England and Wales (1756/7 and 1769/70-1777/78)

\begin{tabular}{|c|c|c|c|c|c|c|c|c|}
\hline England and Wales & Barley & Beans & Malt & Oats and oatmeal & Peas & Rye & Wheat and flour & Total \\
\hline Michaelmas 1756 - Michaelmas 1757 & 3,973 & 1,101 & 5 & 10,037 & 4 & 0 & 17,360 & 32,480 \\
\hline Xmas $1769-$ Xmas 1770 & 98 & 0 & 0 & 1,919 & 0 & 0 & 57 & 2,074 \\
\hline Xmas 1770 - Xmas 1771 & 571 & 0 & 158 & 24,811 & 0 & 0 & 4,320 & 29,860 \\
\hline Xmas 1771 - Xmas 1772 & 7,354 & 17 & 7 & 8,192 & 0 & 149 & 17,491 & 33,210 \\
\hline Xmas 1772 - Xmas 1773 & 26,173 & 6,801 & 0 & 106,870 & 1,046 & 507 & 11,836 & 153,233 \\
\hline Xmas 1773 - Xmas 1774 & 70,777 & 257 & 0 & 42,050 & 317 & 585 & 18,008 & 131,994 \\
\hline Xmas 1774 -Xmas 1775 & 66,378 & 4,196 & 0 & 152,443 & 1,933 & 126 & 52,383 & 277,459 \\
\hline Xmas 1775 - Xmas 1776 & 5,303 & 10,324 & 0 & 228,845 & 497 & 0 & 46,565 & 291,534 \\
\hline Xmas 1776 - Xmas 1777 & 13,468 & 1,791 & 0 & 193,882 & 720 & 927 & 67,781 & 278,569 \\
\hline Xmas $1777-X$ mas 1778 & 48,822 & 0 & 0 & 31,451 & 0 & 67 & 12,072 & 92,412 \\
\hline
\end{tabular}

Notes. Data for $1756 / 7$ refer to the year from Michaelmas 1756 to Michaelmas 1757 . Data for the years $1769 / 70$ to $1777 / 78$ refer to the year from Christmas to Christmas. The original data for $1756 / 57$ and 1769/70-1777/78 were reported in quarters and have been converted to hundredweight by comparing the figures used by Mitchell (1988, pp. 221-2) with the Annual Accounts (see also Floud et al., 2011, p. 158). The same procedure has been used to convert the figures for different grains in 1792-9 from quarters into hundredweight.

Source: John, 1989, p. 1018. 
This article is $\odot$ Emerald Group Publishing and permission has been granted for this version to appear here (http://strathprints.strath.ac.uk/50435/). Emerald does not grant permission for this article to be further copied/distributed or hosted elsewhere without the express permission from Emerald Group Publishing Limited.

Table 19. Irish exports of grain (in quarters) and meal (in cwt) to England and Wales, 1792-1849

\begin{tabular}{|c|c|c|c|c|c|c|c|c|c|c|c|c|c|c|c|}
\hline & \multicolumn{9}{|c|}{ Quarters } & \multicolumn{6}{|c|}{ Hundredweight } \\
\hline & Barley & Beans & Beer or bigg & Indian corn & Malt & Oats & Peas & Rye & Wheat & Barleymeal & Beanmeal & Indian meal & Oatmeal & Ryemeal & $\begin{array}{c}\text { Wheatmeal } \\
\text { or flour }\end{array}$ \\
\hline 1792 & 5,446 & 1,847 & 0 & 0 & 0 & 483,931 & 9 & 491 & 1,270 & 0 & 0 & 0 & 116,039 & 0 & 0 \\
\hline 1793 & 4,285 & 3,312 & 0 & 0 & 0 & 269,465 & 0 & 30 & 13,974 & 0 & 0 & 0 & 36,250 & 0 & 2,080 \\
\hline 1794 & 17,198 & 1,846 & 0 & 0 & 0 & 361,653 & 0 & 414 & 8,551 & 0 & 0 & 0 & 26,646 & 0 & 2,121 \\
\hline 1795 & 0 & 1,984 & 0 & 0 & 0 & 335,920 & 0 & 0 & 13,408 & 0 & 0 & 0 & 30,304 & 0 & 3,796 \\
\hline 1796 & 0 & 879 & 0 & 0 & 0 & 280,416 & 0 & 0 & 0 & 0 & 0 & 0 & 95,881 & 0 & 11 \\
\hline 1797 & 12,268 & 587 & 0 & 0 & 0 & 289,253 & 0 & 0 & 36,489 & 0 & 0 & 0 & 71,304 & 0 & 14,257 \\
\hline 1798 & 49,780 & 3,787 & 0 & 0 & 0 & 310,579 & 51 & 0 & 16,667 & 0 & 0 & 0 & 81,651 & 0 & 2,864 \\
\hline 1799 & 151 & 1,563 & 0 & 0 & 0 & 324,857 & 0 & 0 & 14,773 & 0 & 0 & 0 & 54,135 & 0 & 1,898 \\
\hline 1800 & 79 & 0 & 0 & 0 & 0 & 640 & 0 & 0 & 131 & 0 & 0 & 0 & 2,783 & 0 & 2,164 \\
\hline 1806 & 3,328 & 2,361 & 0 & 0 & 0 & 326,814 & 1,389 & 330 & 91,344 & 0 & 0 & 0 & 77,447 & 0 & 38,265 \\
\hline 1807 & 19,059 & 3,768 & 0 & 0 & 0 & 307,957 & 1,391 & 86 & 38,573 & 0 & 0 & 0 & 51,631 & 0 & 7,487 \\
\hline 1812 & 34,534 & 4,857 & 0 & 0 & 0 & 303,238 & 52 & 178 & 94,276 & 630 & 0 & 0 & 54,787 & 0 & 67,526 \\
\hline 1814 & 16,779 & 5,731 & 0 & 0 & 0 & 534,100 & 460 & 4 & 184,432 & 0 & 0 & 0 & 47,003 & 0 & 143,662 \\
\hline 1815 & 27,108 & 6,371 & 0 & 0 & 0 & 576,545 & 426 & 207 & 159,188 & 0 & 0 & 0 & 32,988 & 0 & 106,243 \\
\hline 1816 & 62,253 & 5,934 & 0 & 0 & 0 & 662,549 & 239 & 43 & 98,205 & 5 & 0 & 0 & 33,259 & 0 & 81,993 \\
\hline 1817 & 26,740 & 2,275 & 0 & 0 & 0 & 594,438 & 12 & 0 & 50,842 & 88 & 0 & 0 & 26,211 & 0 & 16,238 \\
\hline 1818 & 528 & 4,768 & 0 & 0 & 0 & $1,001,248$ & 10 & 4 & 95,677 & 180 & 231 & 0 & 107,073 & 0 & 33,259 \\
\hline 1819 & 20,290 & 3,904 & 0 & 0 & 0 & 759,609 & 0 & 3 & 127,309 & 70 & 0 & 0 & 47,150 & 0 & 928,933 \\
\hline 1820 & 87,028 & 8,396 & 0 & 0 & 0 & 892,665 & 439 & 134 & 351,872 & 229 & 0 & 0 & 37,063 & 0 & 180,375 \\
\hline 1821 & 82,740 & 4,959 & 0 & 0 & 0 & $1,121,234$ & 2,474 & 550 & 485,479 & 495 & 0 & 0 & 64,451 & 0 & 294,774 \\
\hline 1822 & 7,235 & 0 & 0 & 0 & 0 & 549,464 & 728 & 353 & 375,684 & 0 & 0 & 0 & 31,073 & 0 & 305,621 \\
\hline 1823 & 19,274 & 5,540 & 0 & 0 & 0 & $1,039,364$ & 586 & 587 & 290,344 & 0 & 0 & 0 & 99,195 & 0 & 384,032 \\
\hline 1824 & 44,699 & 5,791 & 0 & 0 & 1,173 & $1,139,463$ & 756 & 112 & 260,322 & 0 & 0 & 0 & 134,550 & 0 & 336,219 \\
\hline 1825 & 154,256 & 11,355 & 0 & 0 & 10,826 & $1,500,264$ & 1,431 & 220 & 283,340 & 0 & 0 & 0 & 203,644 & 0 & 394,374 \\
\hline 1830 & 189,093 & 19,053 & 580 & 29 & 2,820 & $1,226,486$ & 2,520 & 414 & 337,641 & 249 & 0 & 0 & 400,347 & 0 & 672,265 \\
\hline 1831 & 184,789 & 15,029 & 620 & 501 & 10,888 & $1,285,738$ & 4,142 & 516 & 407,714 & 0 & 0 & 210 & 581,571 & 0 & 524,242 \\
\hline 1832 & 123,097 & 14,530 & 542 & 2,875 & 8,289 & $1,662,786$ & 1,916 & 294 & 552,740 & 0 & 0 & 553 & 611,412 & 0 & 831,434 \\
\hline 1833 & 100,901 & 19,114 & 866 & 117 & 7,017 & $1,353,533$ & 2,646 & 167 & 541,472 & 0 & 0 & 0 & 64,270 & 0 & $1,059,588$ \\
\hline 1834 & 217,569 & 18,771 & 286 & 0 & 3,865 & $1,277,598$ & 2,176 & 983 & 462,230 & 0 & 0 & 0 & 772,994 & 0 & $1,110,464$ \\
\hline 1835 & 156,176 & 24,235 & 66 & 0 & 10,357 & $1,462,581$ & 2,447 & 615 & 340,535 & 0 & 0 & 0 & 566,007 & 0 & $1,124,343$ \\
\hline
\end{tabular}

Forthcoming in Research in Economic History, 31 (2015) 
This article is $\odot$ Emerald Group Publishing and permission has been granted for this version to appear here (http://strathprints.strath.ac.uk/50435/). Emerald does not grant permission for this article to be further copied/distributed or hosted elsewhere without the express permission from Emerald Group Publishing Limited.

\begin{tabular}{|c|c|c|c|c|c|c|c|c|c|c|c|c|c|c|c|}
\hline 1836 & 182,867 & 17,604 & 1,289 & 0 & 22,214 & $1,642,776$ & 2,920 & 483 & 260,894 & 0 & 0 & 0 & 768,999 & 0 & $1,182,521$ \\
\hline 1837 & 187,019 & 25,630 & 450 & 0 & 4,174 & $1,635,327$ & 2,860 & 1,016 & 253,562 & 15 & 0 & 0 & $1,004,690$ & 0 & 376,541 \\
\hline 1838 & 156,067 & 21,584 & 400 & 0 & 5,001 & $1,945,381$ & 5,232 & 628 & 209,221 & 0 & 0 & 0 & $1,253,098$ & 0 & $1,166,768$ \\
\hline 1839 & 61,676 & 11,535 & 0 & 0 & 2,552 & $1,321,348$ & 1,484 & 2,331 & 98,473 & 0 & 0 & 0 & 917,061 & 0 & 559,504 \\
\hline 1840 & 95,932 & 14,753 & 0 & 0 & 3,456 & $1,401,979$ & 1,403 & 123 & 93,631 & 78 & 0 & 0 & 999,204 & 0 & 282,831 \\
\hline 1841 & 75,557 & 15,907 & 0 & 0 & 4,935 & $1,673,619$ & 855 & 172 & 122,929 & 38 & 0 & 0 & $1,360,481$ & 0 & 335,228 \\
\hline 1842 & 50,287 & 19,832 & 0 & 0 & 3,046 & $1,274,326$ & 1,551 & 76 & 112,195 & 36 & 0 & 0 & $1,551,172$ & 0 & 314,311 \\
\hline 1843 & 110,449 & 24,329 & 0 & 0 & 8,643 & $1,561,997$ & 0 & 372 & 192,477 & 0 & 0 & 0 & $1,706,628$ & 0 & 773,463 \\
\hline 1844 & 20,636 & 18,580 & 0 & 0 & 8,153 & $1,509,870$ & 1,091 & 265 & 200,276 & 0 & 0 & 0 & $1,150,976$ & 0 & 839,567 \\
\hline 1845 & 93,095 & 12,745 & 0 & 0 & 11,154 & $1,679,958$ & 1,645 & 165 & 372,719 & 0 & 0 & 0 & $1,059,185$ & 0 & $1,422,379$ \\
\hline 1846 & 92,854 & 0 & 0 & 0 & 11,329 & 958,851 & 2,227 & 0 & 186,730 & 0 & 0 & 0 & 554,307 & 0 & 723,562 \\
\hline 1847 & 47,528 & 22,362 & 0 & 0 & 5,956 & 493,118 & 4,659 & 1,498 & 123,738 & 0 & 0 & 0 & 330,545 & 0 & 210,995 \\
\hline 1848 & 79,804 & 12,314 & 193 & 0 & 6,365 & 950,780 & 2,572 & 15 & 144,788 & 280 & 0 & 0 & 936,239 & 0 & 560,296 \\
\hline 1849 & 44,592 & 2,240 & 191 & 0 & 5,181 & 666,542 & 3,369 & 345 & 101,865 & 300 & 0 & 0 & 718,826 & 260 & 460,364 \\
\hline
\end{tabular}

Sources: 1792-1799: John, 1989, p. 1018; 1800-49: TNA CUST5/1A-43. 
This article is $\odot$ Emerald Group Publishing and permission has been granted for this version to appear here (http://strathprints.strath.ac.uk/50435/). Emerald does not grant permission for this article to be further copied/distributed or hosted elsewhere without the express permission from Emerald Group Publishing Limited.

\section{Table 20. Calorific value of Irish grain imports}

\begin{tabular}{|c|c|c|c|c|c|c|c|c|c|c|c|c|c|c|c|c|c|}
\hline & $\begin{array}{l}\text { Population } \\
(000 s)\end{array}$ & Barley & $\begin{array}{l}\text { Barley } \\
\text {-meal }\end{array}$ & Beans & $\begin{array}{l}\text { Bean } \\
\text { meal } \\
\end{array}$ & $\begin{array}{l}\text { Beer or } \\
\text { bigg }\end{array}$ & $\begin{array}{l}\text { Indian } \\
\text { corn }\end{array}$ & $\begin{array}{l}\text { Indian } \\
\text { meal }\end{array}$ & Malt & Oats & Oatmeal & Peas & Rye & Ryemeal & Wheat & $\begin{array}{l}\text { Wheat } \\
\text {-meal }\end{array}$ & Total \\
\hline $1756 / 57$ & 6,616 & 0.18 & 0.00 & 0.03 & 0.00 & 0.00 & 0.00 & 0.00 & 0.00 & 0.46 & 0.05 & 0.00 & 0.00 & 0.00 & 0.67 & 0.07 & 1.46 \\
\hline $1769 / 70$ & 7,344 & 0.00 & 0.00 & 0.00 & 0.00 & 0.00 & 0.00 & 0.00 & 0.00 & 0.08 & 0.01 & 0.00 & 0.00 & 0.00 & 0.00 & 0.00 & 0.09 \\
\hline $1770 / 71$ & 7,405 & 0.02 & 0.00 & 0.00 & 0.00 & 0.00 & 0.00 & 0.00 & 0.01 & 1.02 & 0.11 & 0.00 & 0.00 & 0.00 & 0.15 & 0.01 & 1.33 \\
\hline $1771 / 72$ & 7,465 & 0.29 & 0.00 & 0.00 & 0.00 & 0.00 & 0.00 & 0.00 & 0.00 & 0.34 & 0.04 & 0.00 & 0.01 & 0.00 & 0.60 & 0.06 & 1.33 \\
\hline $1772 / 73$ & 7,526 & 1.02 & 0.00 & 0.19 & 0.00 & 0.00 & 0.00 & 0.00 & 0.00 & 4.34 & 0.47 & 0.03 & 0.02 & 0.00 & 0.40 & 0.04 & 6.52 \\
\hline $1773 / 74$ & 7,586 & 2.73 & 0.00 & 0.01 & 0.00 & 0.00 & 0.00 & 0.00 & 0.00 & 1.69 & 0.19 & 0.01 & 0.02 & 0.00 & 0.61 & 0.06 & 5.32 \\
\hline $1774 / 75$ & 7,647 & 2.54 & 0.00 & 0.12 & 0.00 & 0.00 & 0.00 & 0.00 & 0.00 & 6.09 & 0.67 & 0.06 & 0.00 & 0.00 & 1.76 & 0.17 & 11.41 \\
\hline $1775 / 76$ & 7,708 & 0.20 & 0.00 & 0.28 & 0.00 & 0.00 & 0.00 & 0.00 & 0.00 & 9.08 & 0.99 & 0.01 & 0.00 & 0.00 & 1.55 & 0.15 & 12.27 \\
\hline $1776 / 77$ & 7,768 & 0.51 & 0.00 & 0.05 & 0.00 & 0.00 & 0.00 & 0.00 & 0.00 & 7.61 & 0.83 & 0.02 & 0.04 & 0.00 & 2.23 & 0.22 & 11.50 \\
\hline $1777 / 78$ & 7,829 & 1.83 & 0.00 & 0.00 & 0.00 & 0.00 & 0.00 & 0.00 & 0.00 & 1.23 & 0.13 & 0.00 & 0.00 & 0.00 & 0.40 & 0.04 & 3.63 \\
\hline 1792 & 10,122 & 0.55 & 0.00 & 0.16 & 0.00 & 0.00 & 0.00 & 0.00 & 0.00 & 42.37 & 5.76 & 0.00 & 0.06 & 0.00 & 0.14 & 0.00 & 49.04 \\
\hline 1793 & 10,185 & 0.43 & 0.00 & 0.29 & 0.00 & 0.00 & 0.00 & 0.00 & 0.00 & 23.51 & 1.79 & 0.00 & 0.00 & 0.00 & 1.52 & 0.09 & 27.64 \\
\hline 1794 & 10,248 & 1.72 & 0.00 & 0.16 & 0.00 & 0.00 & 0.00 & 0.00 & 0.00 & 31.36 & 1.31 & 0.00 & 0.05 & 0.00 & 0.93 & 0.09 & 35.62 \\
\hline 1795 & 10,310 & 0.00 & 0.00 & 0.17 & 0.00 & 0.00 & 0.00 & 0.00 & 0.00 & 28.96 & 1.48 & 0.00 & 0.00 & 0.00 & 1.44 & 0.15 & 32.21 \\
\hline 1796 & 10,373 & 0.00 & 0.00 & 0.08 & 0.00 & 0.00 & 0.00 & 0.00 & 0.00 & 23.96 & 4.64 & 0.00 & 0.00 & 0.00 & 0.00 & 0.00 & 28.68 \\
\hline 1797 & 10,435 & 1.21 & 0.00 & 0.05 & 0.00 & 0.00 & 0.00 & 0.00 & 0.00 & 24.63 & 3.44 & 0.00 & 0.00 & 0.00 & 3.92 & 0.57 & 33.83 \\
\hline 1798 & 10,498 & 4.86 & 0.00 & 0.32 & 0.00 & 0.00 & 0.00 & 0.00 & 0.00 & 26.29 & 3.92 & 0.00 & 0.00 & 0.00 & 1.76 & 0.11 & 37.28 \\
\hline 1799 & 10,561 & 0.01 & 0.00 & 0.13 & 0.00 & 0.00 & 0.00 & 0.00 & 0.00 & 27.34 & 2.58 & 0.00 & 0.00 & 0.00 & 1.55 & 0.08 & 31.70 \\
\hline 1800 & 10,623 & 0.01 & 0.00 & 0.00 & 0.00 & 0.00 & 0.00 & 0.00 & 0.00 & 0.05 & 0.13 & 0.00 & 0.00 & 0.00 & 0.01 & 0.09 & 0.29 \\
\hline 1806 & 11,378 & 0.30 & 0.00 & 0.19 & 0.00 & 0.00 & 0.00 & 0.00 & 0.00 & 25.53 & 3.43 & 0.12 & 0.03 & 0.00 & 8.92 & 1.41 & 39.92 \\
\hline 1807 & 11,536 & 1.69 & 0.00 & 0.29 & 0.00 & 0.00 & 0.00 & 0.00 & 0.00 & 23.72 & 2.25 & 0.12 & 0.01 & 0.00 & 3.71 & 0.27 & 32.08 \\
\hline 1812 & 12,331 & 2.86 & 0.02 & 0.35 & 0.00 & 0.00 & 0.00 & 0.00 & 0.00 & 21.80 & 2.23 & 0.00 & 0.02 & 0.00 & 8.47 & 2.29 & 38.05 \\
\hline 1814 & 12,725 & 1.35 & 0.00 & 0.40 & 0.00 & 0.00 & 0.00 & 0.00 & 0.00 & 37.30 & 1.86 & 0.03 & 0.00 & 0.00 & 16.10 & 4.74 & 61.79 \\
\hline 1815 & 12,937 & 2.15 & 0.00 & 0.44 & 0.00 & 0.00 & 0.00 & 0.00 & 0.00 & 39.61 & 1.28 & 0.03 & 0.02 & 0.00 & 13.67 & 3.45 & 60.65 \\
\hline 1816 & 13,155 & 4.84 & 0.00 & 0.40 & 0.00 & 0.00 & 0.00 & 0.00 & 0.00 & 44.64 & 1.27 & 0.02 & 0.00 & 0.00 & 8.27 & 2.61 & 62.05 \\
\hline 1817 & 13,364 & 2.05 & 0.00 & 0.15 & 0.00 & 0.00 & 0.00 & 0.00 & 0.00 & 39.53 & 0.99 & 0.00 & 0.00 & 0.00 & 4.23 & 0.51 & 47.46 \\
\hline 1818 & 13,569 & 0.04 & 0.01 & 0.32 & 0.01 & 0.00 & 0.00 & 0.00 & 0.00 & 65.58 & 3.97 & 0.00 & 0.00 & 0.00 & 7.83 & 1.03 & 78.78 \\
\hline 1819 & 13,765 & 1.51 & 0.00 & 0.25 & 0.00 & 0.00 & 0.00 & 0.00 & 0.00 & 49.04 & 1.73 & 0.00 & 0.00 & 0.00 & 10.27 & 28.33 & 91.14 \\
\hline 1820 & 13,974 & 6.37 & 0.01 & 0.54 & 0.00 & 0.00 & 0.00 & 0.00 & 0.00 & 56.62 & 1.33 & 0.03 & 0.01 & 0.00 & 27.90 & 5.40 & 98.20 \\
\hline 1821 & 14,206 & 5.97 & 0.02 & 0.31 & 0.00 & 0.00 & 0.00 & 0.00 & 0.00 & 70.14 & 2.29 & 0.17 & 0.05 & 0.00 & 37.96 & 8.71 & 125.62 \\
\hline 1822 & 14,446 & 0.51 & 0.00 & 0.00 & 0.00 & 0.00 & 0.00 & 0.00 & 0.00 & 33.80 & 1.08 & 0.05 & 0.03 & 0.00 & 28.89 & 8.88 & 73.25 \\
\hline
\end{tabular}

Forthcoming in Research in Economic History, 31 (2015) 
This article is $\odot$ Emerald Group Publishing and permission has been granted for this version to appear here (http://strathprints.strath.ac.uk/50435/). Emerald does not grant permission for this article to be further copied/distributed or hosted elsewhere without the express permission from Emerald Group Publishing Limited.

\begin{tabular}{|c|c|c|c|c|c|c|c|c|c|c|c|c|c|c|c|c|c|}
\hline 1823 & 14,681 & 1.35 & 0.00 & 0.34 & 0.00 & 0.00 & 0.00 & 0.00 & 0.00 & 62.92 & 3.40 & 0.04 & 0.05 & 0.00 & 21.97 & 10.98 & 101.04 \\
\hline 1824 & 14,900 & 3.07 & 0.00 & 0.35 & 0.00 & 0.00 & 0.00 & 0.00 & 0.06 & 67.78 & 4.54 & 0.05 & 0.01 & 0.00 & 19.36 & 9.45 & 104.65 \\
\hline 1825 & 15,108 & 10.47 & 0.00 & 0.68 & 0.00 & 0.00 & 0.00 & 0.00 & 0.51 & 88.25 & 6.79 & 0.09 & 0.02 & 0.00 & 20.83 & 10.96 & 138.60 \\
\hline 1830 & 16,150 & 12.01 & 0.01 & 1.06 & 0.00 & 0.03 & 0.00 & 0.00 & 0.12 & 67.49 & 12.49 & 0.15 & 0.03 & 0.00 & 23.22 & 17.47 & 134.09 \\
\hline 1831 & 16,368 & 11.58 & 0.00 & 0.83 & 0.00 & 0.03 & 0.01 & 0.01 & 0.47 & 69.81 & 17.90 & 0.24 & 0.04 & 0.00 & 27.67 & 13.44 & 142.03 \\
\hline 1832 & 16,563 & 7.60 & 0.00 & 0.79 & 0.00 & 0.03 & 0.05 & 0.02 & 0.36 & 88.98 & 18.54 & 0.11 & 0.02 & 0.00 & 36.97 & 21.01 & 174.47 \\
\hline 1833 & 16,750 & 6.18 & 0.00 & 1.03 & 0.00 & 0.05 & 0.00 & 0.00 & 0.30 & 71.82 & 1.93 & 0.15 & 0.01 & 0.00 & 35.91 & 26.55 & 143.92 \\
\hline 1834 & 16,967 & 13.15 & 0.00 & 0.99 & 0.00 & 0.01 & 0.00 & 0.00 & 0.16 & 66.92 & 22.95 & 0.12 & 0.07 & 0.00 & 30.26 & 27.47 & 162.12 \\
\hline 1835 & 17,196 & 9.31 & 0.00 & 1.27 & 0.00 & 0.00 & 0.00 & 0.00 & 0.43 & 75.59 & 16.58 & 0.14 & 0.04 & 0.00 & 22.00 & 27.45 & 152.80 \\
\hline 1836 & 17,425 & 10.73 & 0.00 & 0.91 & 0.00 & 0.07 & 0.00 & 0.00 & 0.90 & 83.56 & 22.17 & 0.16 & 0.03 & 0.00 & 16.59 & 28.41 & 163.52 \\
\hline 1837 & 17,627 & 10.88 & 0.00 & 1.31 & 0.00 & 0.02 & 0.00 & 0.00 & 0.17 & 82.45 & 28.71 & 0.16 & 0.07 & 0.00 & 15.98 & 8.97 & 148.71 \\
\hline 1838 & 17,836 & 8.97 & 0.00 & 1.09 & 0.00 & 0.02 & 0.00 & 0.00 & 0.20 & 96.93 & 35.39 & 0.28 & 0.04 & 0.00 & 13.03 & 27.46 & 183.41 \\
\hline 1839 & 18,088 & 3.50 & 0.00 & 0.57 & 0.00 & 0.00 & 0.00 & 0.00 & 0.10 & 64.92 & 25.54 & 0.08 & 0.15 & 0.00 & 6.05 & 12.98 & 113.89 \\
\hline 1840 & 18,332 & 5.35 & 0.00 & 0.72 & 0.00 & 0.00 & 0.00 & 0.00 & 0.13 & 67.78 & 27.38 & 0.07 & 0.01 & 0.00 & 5.66 & 6.46 & 113.57 \\
\hline 1841 & 18,551 & 4.18 & 0.00 & 0.77 & 0.00 & 0.00 & 0.00 & 0.00 & 0.19 & 80.18 & 36.94 & 0.04 & 0.01 & 0.00 & 7.36 & 7.59 & 137.26 \\
\hline 1842 & 18,783 & 2.75 & 0.00 & 0.95 & 0.00 & 0.00 & 0.00 & 0.00 & 0.12 & 60.29 & 41.60 & 0.08 & 0.00 & 0.00 & 6.64 & 7.02 & 119.45 \\
\hline 1843 & 19,016 & 5.96 & 0.00 & 1.15 & 0.00 & 0.00 & 0.00 & 0.00 & 0.32 & 73.00 & 45.21 & 0.00 & 0.02 & 0.00 & 11.24 & 17.07 & 153.98 \\
\hline 1844 & 19,248 & 1.10 & 0.00 & 0.86 & 0.00 & 0.00 & 0.00 & 0.00 & 0.30 & 69.52 & 30.04 & 0.05 & 0.02 & 0.00 & 11.53 & 18.26 & 131.68 \\
\hline 1845 & 19,481 & 4.90 & 0.00 & 0.59 & 0.00 & 0.00 & 0.00 & 0.00 & 0.41 & 76.64 & 27.39 & 0.08 & 0.01 & 0.00 & 21.25 & 30.65 & 161.92 \\
\hline 1846 & 19,714 & 4.83 & 0.00 & 0.00 & 0.00 & 0.00 & 0.00 & 0.00 & 0.41 & 43.23 & 14.16 & 0.11 & 0.00 & 0.00 & 10.52 & 15.41 & 88.66 \\
\hline 1847 & 19,947 & 2.44 & 0.00 & 1.01 & 0.00 & 0.00 & 0.00 & 0.00 & 0.21 & 21.97 & 8.35 & 0.22 & 0.09 & 0.00 & 6.89 & 4.44 & 45.62 \\
\hline 1848 & 20,180 & 4.04 & 0.01 & 0.55 & 0.00 & 0.01 & 0.00 & 0.00 & 0.22 & 41.76 & 23.31 & 0.12 & 0.00 & 0.00 & 7.95 & 11.62 & 89.59 \\
\hline 1849 & 20,413 & 2.24 & 0.01 & 0.10 & 0.00 & 0.01 & 0.00 & 0.00 & 0.18 & 29.02 & 17.74 & 0.16 & 0.02 & 0.01 & 5.54 & 9.47 & 64.49 \\
\hline
\end{tabular}

Notes. The ratios of processed foods (flour and oatmeal) to raw cereals (wheat and oats) during the period $1792-9$ have been used to estimate the relative amounts of oats and oatmeal, and wheat and flour, for the years $1756 / 7$ and 1769/70-1777/78. We have assumed that 35 per cent of the raw crop was lost in processing and that $10 \%$ of the processed crop was lost in distribution and wastage (see also Floud et al., 2011, pp. 212-6). Population figures for 1756/7
and $1769 / 70-1779 / 80$ have been calculated by interpolation, using the data for England and Wales 1750 and 1800 in Floud et al. (2011, pp. $205-9$ ). Population figures for $1792-1800$ have been calculated using the same method, using
population figures for the whole of Great Britain (England, Scotland and Wales). The remaining population figures have been calculated using the annual totals for Scotland and England and Wales in Mitchell (1988, Table 1.3). Sources: Imports: see Tables 18 and 19; calorie values and extraction rates: Floud et al., 201 1, pp. 212-6; Population: Floud et al., 2011, pp. 205-9; Mitchell, 1988, Table 1.3. 
This article is (c) Emerald Group Publishing and permission has been granted for this version to appear here

(http://strathprints.strath.ac.uk/50435/). Emerald does not grant permission for this article to be further copied/distributed or hosted elsewhere without the express permission from Emerald Group Publishing Limited.

\subsection{Irish meat and dairy exports}

As we have already seen, there was a substantial increase in the value of Irish meat and dairy imports during the second half of the eighteenth century. Davis' figures suggest that the value of Irish butter imports more than doubled between 1784/86 and $1824 / 26$, whilst the value of imported beef and pork increased by a factor of more than five. How significant was the contribution made by these changes to the average British diet?

In 1968, Leslie Cullen published data on the volume of food imported into Great Britain in the form of barrels of beef and pork and hundredweights of butter. His figures suggested that the quantity of imported beef increased by a factor of five between 1760 and 1800 , whilst the amount of butter increased by a factor six and that of pork by more than seven (Table 21 ). John Macgregor (1850, p. 158) published data for the combined totals of beef and pork, together with butter, for the periods $1787-9,1797-9,1807-9,1817-19$ and 1823-5. Although there are some differences in the figures showing exports to the rest of the world, the figures for exports to Great Britain are fairly similar where the periods overlap, which suggests that we can use Macgregor's data to extend Cullen's series. However, this does not necessarily mean that the figures are comparable across the period as a whole. Cullen argued that the data which were gathered before 1780 may not be entirely comparable with the post-1780 data because of changes in reporting procedures and, more importantly, he also argued that almost all of the imported beef (and, perhaps, much of the imported pork) was either diverted to the navy or re-exported to the West Indies (Cullen, 1968, p. 73). 
This article is (c) Emerald Group Publishing and permission has been granted for this version to appear here

(http://strathprints.strath.ac.uk/50435/). Emerald does not grant permission for this article to be further copied/distributed or hosted elsewhere without the express permission from Emerald Group Publishing Limited.

Table 21. Irish beef, butter and pork exported to Great Britain, 1760-1800.

\begin{tabular}{|c|c|c|c|c|c|c|c|c|}
\hline \multirow[t]{2}{*}{ Cullen } & \multicolumn{2}{|c|}{ Beef (in barrels) } & \multicolumn{2}{|c|}{ Pork (in barrels) } & \multicolumn{2}{|c|}{ Beef and pork (in barrels) } & \multicolumn{2}{|c|}{ Butter (cwt) } \\
\hline & To GB & To all parts & To GB & To all parts & To GB & To all parts & To GB & To all parts \\
\hline 1760 & 24,072 & 164,903 & 13,293 & 54,401 & 37,365 & 219,304 & 35,162 & 229,227 \\
\hline 1765 & 20,108 & 199,999 & 7,283 & 44,361 & 27,391 & 244,360 & 38,026 & 301,109 \\
\hline 1770 & 31,275 & 208,269 & 12,089 & 43,947 & 43,364 & 252,216 & 114,363 & 262,717 \\
\hline 1775 & 36,455 & 192,452 & 17,199 & 50,367 & 53,654 & 242,819 & 244,185 & 264,140 \\
\hline 1780 & 89,698 & 187,756 & 49,302 & 96,554 & 139,000 & 284,310 & 135,465 & 244,185 \\
\hline 1785 & 43,024 & 136,651 & 21,539 & 58,446 & 64,563 & 195,097 & 159,526 & 282,802 \\
\hline 1790 & 51,203 & 226,994 & 46,067 & 100,266 & 97,270 & 327,260 & 194,748 & 300,669 \\
\hline 1795 & 95,475 & 124,607 & 88,304 & 129,922 & 183,779 & 254,529 & 214,962 & 276,403 \\
\hline 1800 & 123,947 & 149,857 & 98,348 & 114,745 & 222,295 & 264,602 & 208,683 & 263,290 \\
\hline \multirow[t]{2}{*}{ Macgregor } & \multicolumn{2}{|c|}{ Beef (in barrels) } & \multicolumn{2}{|c|}{ Pork (in barrels) } & \multicolumn{2}{|c|}{ Beef and pork (in barrels) } & \multicolumn{2}{|c|}{ Butter (cwt) } \\
\hline & To GB & To all parts & To GB & To all parts & To GB & To all parts & To GB & To all parts \\
\hline $1788-1790^{\circ}$ & - & - & - & - & 88,583 & 138,981 & 198,149 & 120,900 \\
\hline $1798-1800^{\circ}$ & - & - & - & - & 229,179 & 48,897 & 215,100 & 65,549 \\
\hline $1808-1810^{\circ}$ & - & - & - & - & 211,482 & 66,824 & 309,179 & 46,423 \\
\hline $1818-1820^{+}$ & - & - & - & - & 170,362 & 54,858 & 378,303 & 65,553 \\
\hline $1824-1826^{\dagger}$ & - & - & - & - & 143,725 & 46,206 & 441,226 & 51,637 \\
\hline
\end{tabular}

Notes. "Average of three years ending $25 \mathrm{March} .{ }^{\dagger}$ Average of three years ending 5 January. ${ }^{\ddagger}$ One barrel was equivalent to approximately $2 \mathrm{cwt}$. Sources: Cullen, 1968, p. 70; Macgregor, 1850, p. 158.

It is important to bear these considerations in mind when estimating the calorific value of these items. The data in Tables 22 and 23 suggest that, even if the beef had been consumed in Great Britain, it would only have contributed around nine calories per head at the end of the eighteenth century. The number of calories derived from imported pork and butter was also relatively low. Our calculations suggest that the combined total for beef and pork rose from less than ten calories per head during the 1790 s to just over twenty during the Napoleonic Wars, before falling back. However, the number of calories derived from Irish butter increased after the turn of the century, reaching a peak (so far as the available data are concerned) of just under 40 calories per day during the mid-1820s. 
This article is (c) Emerald Group Publishing and permission has been granted for this version to appear here

(http://strathprints.strath.ac.uk/50435/). Emerald does not grant permission for this article to be further copied/distributed or hosted elsewhere without the express permission from Emerald Group Publishing Limited.

Table 22. Calories derived from beef, butter and pork exported from Ireland to Great Britain, 1760-1800.

\begin{tabular}{|c|c|c|c|c|c|c|c|c|c|c|c|}
\hline & Beef (lbs) & Pork (lbs) & $\begin{array}{c}\text { Butter } \\
\text { (lbs) }\end{array}$ & Beef & Pork & Butter & $\begin{array}{c}\text { Population } \\
\text { (GB) }\end{array}$ & \multicolumn{4}{|c|}{ Calories per day } \\
\hline & to $\mathrm{GB}$ & to $\mathrm{GB}$ & to $\mathrm{GB}$ & Cals/lb & Cals/lb & Cals/lb & & Beef & Pork & Butter & Total \\
\hline 1760 & $5,392,128$ & $2,977,632$ & $3,938,144$ & 1318.18 & 2040.95 & 3,612 & $8,118,348$ & 2.40 & 2.05 & 4.80 & 9.25 \\
\hline 1765 & $4,504,192$ & $1,631,392$ & $4,258,912$ & 1318.18 & 2040.95 & 3,612 & $8,431,476$ & 1.93 & 1.08 & 5.00 & 8.01 \\
\hline 1770 & $7,005,600$ & $2,707,936$ & $12,808,656$ & 1318.18 & 2040.95 & 3,612 & $8,774,604$ & 2.88 & 1.73 & 14.45 & 19.06 \\
\hline 1775 & $8,165,920$ & $3,852,576$ & $27,348,720$ & 1318.18 & 2040.95 & 3,612 & $9,057,733$ & 3.26 & 2.38 & 29.88 & 35.52 \\
\hline 1780 & $20,092,352$ & $11,043,648$ & $15,172,080$ & 1318.18 & 2040.95 & 3,612 & $9,370,861$ & 7.74 & 6.59 & 16.02 & 30.36 \\
\hline 1785 & $9,637,376$ & $4,824,736$ & $17,866,912$ & 1318.18 & 2040.95 & 3,612 & $9,683,989$ & 3.59 & 2.79 & 18.26 & 24.64 \\
\hline 1790 & $11,469,472$ & $10,319,008$ & $21,811,776$ & 1318.18 & 2040.95 & 3,612 & $9,997,118$ & 4.14 & 5.77 & 21.59 & 31.51 \\
\hline 1795 & $21,386,400$ & $19,780,096$ & $24,075,744$ & 1318.18 & 2040.95 & 3,612 & $10,310,246$ & 7.49 & 10.73 & 23.11 & 41.33 \\
\hline 1800 & $27,764,128$ & $22,029,952$ & $23,372,496$ & 1318.18 & 2040.95 & 3,612 & $10,623,374$ & 9.44 & 11.60 & 21.77 & 42.81 \\
\hline
\end{tabular}

Notes: Population figures have been calculated using the estimates for 1750 and 1800 in Floud et al. (2011, p. 216).

Sources: Food imports: see Table 19; Calorie values: see Table 14; Population figures: Floud et al. $2011: 216$.

Table 23. Calories derived from beef, butter and pork exported from Ireland to Great Britain, 1787/90-1824/26.

\begin{tabular}{|c|c|c|c|c|c|c|c|c|}
\hline $\begin{array}{l}\text { Average of } \\
3 \text { years ending }\end{array}$ & $\begin{array}{l}\text { Beef and pork } \\
\text { (Ibs) }\end{array}$ & Butter (Ibs) & $\begin{array}{l}\text { Beef and } \\
\text { pork (Ibs) }\end{array}$ & $\begin{array}{l}\text { Butter } \\
\text { (Ibs) }\end{array}$ & $\begin{array}{l}\text { Population } \\
\text { (GB) }\end{array}$ & \multicolumn{3}{|c|}{ Calories per day } \\
\hline & & to $G B$ & Cals/lb & Cals/lb & & $\begin{array}{l}\text { Beef \& } \\
\text { pork }\end{array}$ & Butter & Total \\
\hline $25 / 3 / 1790$ & $19,842,592$ & $22,192,688$ & $1,654.63$ & 3,612 & $9,871,866$ & 9.11 & 22.25 & 31.36 \\
\hline $25 / 3 / 1800$ & $51,336,096$ & $24,091,200$ & $1,654.63$ & 3,612 & $10,498,123$ & 22.17 & 22.71 & 44.88 \\
\hline $5 / 1 / 1810$ & $47,371,968$ & $34,628,048$ & $1,654.63$ & 3,612 & $9,791,000$ & 21.93 & 35.00 & 56.94 \\
\hline $5 / 1 / 1820$ & $38,161,088$ & $42,369,936$ & $1,654.63$ & 3,612 & $11,376,000$ & 15.21 & 36.86 & 52.07 \\
\hline $5 / 1 / 1826$ & $32,194,400$ & $49,417,312$ & $1,654.63$ & 3,612 & $12,523,000$ & 11.65 & 39.06 & 50.71 \\
\hline
\end{tabular}

Notes. The average number of calories per pound of beef and pork has been calculated using the data for beef and pork in 1790 , 1795 and 1800 in Table 21. Population figures for the three-year periods ending 25 March 1790 and 25 March 1800 are for the years 1787-9 and 1797-9 and have been calculated using the population estimates for 1750 and 1800 in Floud et al. (2011, p. 216). Population figures for the three-year periods ending 5 January 1810,1820 and 1826 are for the years 1807-9, 1817-19 and $1823-5$, and have been calculated using the annual data in Mitchell (1988, Table I.3).

Sources: See Tables 20 and 21 .

Although much of this discussion has focused on the value of preserved meats and butter, there was also a growing trade in the importation of live animals. John (1989, pp. 1021-2) published information about the numbers of cattle, sheep and pigs (as well as horses) imported into the whole of Great Britain in the periods $1787-90$ and 1797-1800, and in each year from 1801 to 1825 . He also provided information about the numbers of animals entering Liverpool between 1832 and 
This article is (c) Emerald Group Publishing and permission has been granted for this version to appear here

(http://strathprints.strath.ac.uk/50435/). Emerald does not grant permission for this article to be further copied/distributed or hosted elsewhere without the express permission from Emerald Group Publishing Limited.

1839, and Great Britain between 1846 and 1849. ${ }^{5}$ These figures can be combined

with Holderness' (1989, pp. 155-9) data on the average weights of different types of animal to generate initial estimates of food availability.

The results of these calculations are shown in Table 24. Although the number of calories derived from Irish meat increased during the first half of the nineteenth century, it did so from a very low base. Given the significance of the Famine, the absence of national figures during the first half of the 1840 s is clearly unfortunate. However, our data suggest that, even in 1846 , the average number of calories derived from this source was only 48 , and over the next three years it averaged below 35 .

Similar data were published by Porter $(1851$, p. 343) for the years $1801,1805,1809,1813$, 1817,1821 and 1825 . The data were identical except for the fact that Porter recorded the number of sheep imported in 1805 as 10,938 rather than 10,988. He also reported that the number of cattle imported through Liverpool in 1831 was 91,911 as opposed to 91,913, and he provided separate figures for Bristol in 1831 and 1832. Both authors reported the number of animals imported into the whole of Great Britain during the years 1846-9, but Porter provided separate information for 'oxen, cows and bulls' and 'calves'. 
This article is $\odot$ Emerald Group Publishing and permission has been granted for this version to appear here (http://strathprints.strath.ac.uk/50435/). Emerald does not grant permission for this article to be further copied/distributed or hosted elsewhere without the express permission from Emerald Group Publishing Limited.

Table 24. Calories obtained from imported Irish livestock, 1797/1800-1849

\begin{tabular}{|c|c|c|c|c|c|c|c|c|c|c|c|c|c|c|c|c|}
\hline & \multicolumn{3}{|c|}{ Animals } & \multicolumn{3}{|c|}{ Carcase weight (lbs) } & \multicolumn{4}{|c|}{ Calories per pound } & \multirow[t]{2}{*}{ Population (GB) } & \multicolumn{5}{|c|}{ Calories per person per day } \\
\hline & Cattle & Sheep & Pigs & Cattle & Sheep & Pigs & Cattle & Sheep & Pigs & Lard & & Cattle & Sheep & Pigs & Lard & Total \\
\hline $1797-1800$ & 14,105 & 371 & 4,083 & 600 & 68 & 112 & 1318.18 & 1472.12 & 2040.95 & 4040.40 & $10,686,000$ & 2.86 & 0.01 & 0.24 & 0.00 & 3.11 \\
\hline 1801 & 31,453 & 2,879 & 1,968 & 600 & 68 & 112 & 1318.18 & 1472.12 & 2040.95 & 4040.40 & $10,686,000$ & 6.40 & 0.07 & 0.12 & 0.00 & 6.59 \\
\hline 1802 & 42,501 & 4,439 & 11,728 & 600 & 68 & 112 & 1318.18 & 1472.12 & 2040.95 & 4040.40 & $10,774,000$ & 8.55 & 0.11 & 0.68 & 0.00 & 9.34 \\
\hline 1803 & 28,016 & 7,474 & 12,968 & 600 & 68 & 112 & 1318.18 & 1472.12 & 2040.95 & 4040.40 & $10,898,000$ & 5.57 & 0.19 & 0.75 & 0.00 & 6.51 \\
\hline 1846 & 192,846 & 259,257 & 480,827 & 730 & 86 & 129 & 1318.18 & 1472.12 & 2040.95 & 4040.40 & $19,714,000$ & 25.79 & 4.56 & 17.59 & 0.05 & 47.99 \\
\hline 1847 & 199,195 & 324,179 & 106,407 & 730 & 86 & 129 & 1318.18 & 1472.12 & 2040.95 & 4040.40 & $19,947,000$ & 26.33 & 5.64 & 3.85 & 0.01 & 35.82 \\
\hline 1848 & 204,128 & 255,682 & 110,787 & 730 & 86 & 129 & 1318.18 & 1472.12 & 2040.95 & 4040.40 & $20,180,000$ & 26.67 & 4.39 & 3.96 & 0.01 & 35.03 \\
\hline 1849 & 211,642 & 241,061 & 68,053 & 730 & 86 & 129 & 1318.18 & 1472.12 & 2040.95 & 4040.40 & $20,413,000$ & 27.33 & 4.10 & 2.40 & 0.01 & 33.84 \\
\hline
\end{tabular}

Notes: We have used the population figure for 1801 to calculate average daily consumption in 1797-1800.

Sources: Livestock: John, 1989, pp. 1021-2; Weights: Holderness, 1989, pp. 155-9; Calorie values: Floud et al., 201 1, Table D4; Population: Mitchell, 1988, Table 1.3. 
This article is (c) Emerald Group Publishing and permission has been granted for this version to appear here

(http://strathprints.strath.ac.uk/50435/). Emerald does not grant permission for this article to be further copied/distributed or hosted elsewhere without the express permission from Emerald Group Publishing Limited.

\subsection{Irish potatoes}

Although Ireland was a net exporter of potatoes for much of this period, the extent of this trade is difficult to determine. The information in the extant customs ledgers suggests that Irish potatoes made a relatively insignificant contribution to British food supplies before 1825 . However, these figures may be incomplete. In 1817, the Under-Secretary for Ireland, William Gregory, reported that 391 tons of potatoes had been exported from Ireland during the first three months of the year, whilst 967 tons had been imported into the country (Gash, 1985, p. 221). Austin Bourke (1993, p. 105) thought that these figures were atypical but the import figure was much greater than the figure recorded in the customs ledgers for the whole of the year (see Table 24). Meanwhile, Bourke himself also suggested that as many as 250,000 tons may have been exported from Ireland to the rest of the United Kingdom in a 'normal' pre-Famine year.

In view of these differences, it is difficult to offer precise estimates with any degree of confidence. The information in the customs ledgers suggests that Irish potatoes made a negligible contribution to British food consumption in 1800 and that the contribution continued to be negligible for the next quarter-century. On the other hand, these data are contradicted by William Gregory's testimony and are difficult to reconcile with Bourke's figure for circa 1841. One option might be to take his figure as accurate and use it to extrapolate a figure for the earlier year. If the consumption of Irish potatoes grew at the same rate as the consumption of home-produced potatoes, the total number of calories obtained from this source at the start of the nineteenth century could have been as high as 19.77 calories but this may well be an over-estimate. ${ }^{6}$

$6 \quad$ According to Mitchell (1988, Table 1.3), the population of Great Britain in 1841 was $18,551,000$. If Ireland exported 250,000 tons of potatoes, that would imply that each person received 30.44 calories per day (with no allowance for any further wastage). If 
This article is (c) Emerald Group Publishing and permission has been granted for this version to appear here

(http://strathprints.strath.ac.uk/50435/). Emerald does not grant permission for this article to be further copied/distributed or hosted elsewhere without the express permission from Emerald Group Publishing Limited.

In addition to the role played by Irish potatoes, it may also be worth

considering the contribution made by other parts of the world, including the

Channel Islands and the Isle of Man. The recorded figures suggest that the volume

of potatoes imported from the rest of the world exceeded the total volume of Irish

potatoes in 13 of the 16 years for which data exist between 1800 and 1825 but,

even if these figures are correct, the implied contribution to British consumption

remains very low. Indeed, the information in Table 25 suggests that the number of

calories obtained from these sources was less than five calories per day in every

year before 1842.

Table 25. Recorded potato imports, 1800-49

\begin{tabular}{|c|c|c|c|c|c|c|c|c|c|c|c|}
\hline & & \multicolumn{2}{|c|}{ Irish Potatoes } & \multicolumn{2}{|c|}{ Rest of the World } & & & \multicolumn{2}{|c|}{ Ireland } & \multicolumn{2}{|c|}{ Rest of World } \\
\hline & Population (GB) & Cwt & kCal & Cwt & kCal & & Population (GB) & Cwt & $\mathrm{kCal}$ & Cwt & $\mathrm{kCa}$ \\
\hline 1800 & $10,623,374$ & 809.25 & 0.01 & $8,210.00$ & 0.09 & 1830 & $16,150,000$ & $n / a$ & $n / a$ & $184,797.26$ & 1.29 \\
\hline 1806 & $11,378,000$ & $5,301.00$ & 0.05 & $1,103.25$ & 0.01 & 1831 & $16,368,000$ & $n / a$ & $n / a$ & $159,490.51$ & 1.10 \\
\hline 1807 & $11,536,000$ & $6,987.75$ & 0.07 & $15,837.50$ & 0.16 & 1832 & $16,563,000$ & $n / a$ & $n / a$ & $66,897.75$ & 0.46 \\
\hline 1812 & $12,331,000$ & $3,336.75$ & 0.03 & $11,065.25$ & 0.10 & 1833 & $16,750,000$ & $n / a$ & $n / a$ & $134,699.26$ & 0.91 \\
\hline 1814 & $12,725,000$ & $8,548.75$ & 0.08 & $13,928.25$ & 0.12 & 1834 & $16,967,000$ & $n / a$ & $n / a$ & $98,727.26$ & 0.66 \\
\hline 1815 & $12,937,000$ & $2,765.25$ & 0.02 & $10,522.25$ & 0.09 & 1835 & $17,196,000$ & $n / a$ & $n / a$ & $136,180.51$ & 0.89 \\
\hline 1816 & $13,155,000$ & $10,900.00$ & 0.09 & $19,575.50$ & 0.17 & 1836 & $17,425,000$ & $n / a$ & $n / a$ & $237,999.76$ & 1.54 \\
\hline 1817 & $13,364,000$ & $3,778.25$ & 0.03 & $59,904.75$ & 0.51 & 1837 & $17,627,000$ & $n / a$ & $n / a$ & $430,415.77$ & 2.76 \\
\hline 1818 & $13,569,000$ & $43,293.75$ & 0.36 & $127,550.51$ & 1.06 & 1838 & $17,836,000$ & $n / a$ & $n / a$ & $449,103.53$ & 2.84 \\
\hline 1819 & $13,765,000$ & $50,388.75$ & 0.41 & $49,551.75$ & 0.41 & 1839 & $18,088,000$ & $n / a$ & $n / a$ & $611,861.03$ & 3.82 \\
\hline 1820 & $13,974,000$ & $4,958.25$ & 0.04 & $46,429.00$ & 0.38 & 1840 & $18,332,000$ & $n / a$ & $n / a$ & $673,045.54$ & 4.15 \\
\hline 1821 & $14,206,000$ & $38,263.00$ & 0.30 & $32,321.50$ & 0.26 & 1841 & $18,551,000$ & $n / a$ & $n / a$ & $551,400.03$ & 3.36 \\
\hline 1822 & $14,446,000$ & $3,886.00$ & 0.03 & $34,598.50$ & 0.27 & 1842 & $18,783,000$ & $n / a$ & $n / a$ & $831,699.54$ & 5.00 \\
\hline 1823 & $14,681,000$ & $11,317.00$ & 0.09 & $38,774.75$ & 0.30 & 1843 & $19,016,000$ & $n / a$ & $n / a$ & $15,584.75$ & 0.09 \\
\hline 1824 & $14,900,000$ & $5,622.00$ & 0.04 & $74,281.76$ & 0.56 & 1844 & $19,248,000$ & $n / a$ & $n / a$ & $116,909.01$ & 0.69 \\
\hline 1825 & $15,108,000$ & $35,215.50$ & 0.26 & $129,486.26$ & 0.97 & 1845 & $19,481,000$ & $n / a$ & $\mathrm{n} / \mathrm{a}$ & $109,616.01$ & 0.64 \\
\hline 1826 & $15,307,000$ & $n / a$ & $\mathrm{n} / \mathrm{a}$ & $53,522.50$ & 0.39 & 1846 & $19,714,000$ & $n / a$ & $n / a$ & $176,096.76$ & 1.01 \\
\hline 1827 & $15,506,000$ & $n / a$ & $n / a$ & $109,652.76$ & 0.80 & 1847 & $19,947,000$ & $n / a$ & $\mathrm{n} / \mathrm{a}$ & $246,942.01$ & 1.40 \\
\hline 1828 & $15,726,000$ & $n / a$ & $n / a$ & $106,438.51$ & 0.76 & 1848 & $20,180,000$ & $n / a$ & $\mathrm{n} / \mathrm{a}$ & $934,414.05$ & 5.23 \\
\hline 1829 & $15,941,000$ & $n / a$ & $n / a$ & $156,812.26$ & 1.11 & 1849 & $20,413,000$ & $n / a$ & $\mathrm{n} / \mathrm{a}$ & $1,412,986.07$ & 7.82 \\
\hline
\end{tabular}

Source: TNA CUST5/1A-43.

\section{Food availability in a high-wage economy?}

By comparing Floud et al.'s corrected data with the information provided by Overton and Campbell and Broadberry et al., it is possible to identify a number of ways in

consumption increased at the same rate as the consumption of home-produced potatoes, that would imply that the average person obtained 19.44 calories per day in 1800. That is equivalent to the importation of just under 93,000 tons of potatoes in a normal year. 
This article is (c) Emerald Group Publishing and permission has been granted for this version to appear here

(http://strathprints.strath.ac.uk/50435/). Emerald does not grant permission for this article to be further copied/distributed or hosted elsewhere without the express permission from Emerald Group Publishing Limited.

which their estimates might be amended. In particular, one might be tempted to

substitute Overton and Campbell's extraction rates for the figures which Floud et al.

used to convert the amount of food grown in the form of wheat, barley, oats and

rye into calories available for human consumption. As we have already seen, the

effect of these changes would be to increase Floud et al.'s estimates for the years

1700,1750 and 1800 by between 56 and 72 calories per person per day in the case

of Estimate A and between 56 and 99 calories in the case of Estimate B. Overton

and Campbell's ratios also imply that Floud et al. overestimated the number of

calories available in 1850 by between 27 and 32 calories, but the effect of this

change would be more than cancelled out by the inclusion of Irish imports (see

Table 26).

Table 26. Floud et al.'s corrected estimates with Overton and Campbell's extraction rates and Irish dairy, meat and grain imports

\begin{tabular}{|c|c|c|c|c|c|}
\hline & 1700 & 1750 & 1800 & 1850 & $1909 / 13$ \\
\hline Floud et al. A (Original figures) & $2,228.63$ & $2,099.96$ & $2,472.12$ & $2,504.08$ & $2,976.72$ \\
\hline Floud et al. B (Original figures) & $2,228.63$ & $2,237.31$ & $2,438.89$ & $2,544.37$ & $2,976.72$ \\
\hline Floud et al. A (Corrected figures) & $2,228.63$ & $2,327.16$ & $2,472.12$ & $2,504.08$ & $2,976.72$ \\
\hline Floud et al. B (Corrected figures) & $2,228.63$ & $2,515.32$ & $2,438.89$ & $2,544.37$ & $2,976.72$ \\
\hline Floud et al. A with Overton \& Campbell's extraction rates & $2,284.91$ & $2,399.32$ & $2,543.79$ & $2,476.85$ & $2,976.72$ \\
\hline Floud et al. B with Overton $\&$ Campbell's extraction rates & $2,284.91$ & $2,614.58$ & $2,506.36$ & $2,512.05$ & $2,976.72$ \\
\hline Irish grain imports" & 0.00 & 0.00 & 31.70 & 64.49 & - \\
\hline Irish meat imports" & 0.00 & 0.00 & 10.52 & 5.83 & - \\
\hline Irish butter imports ${ }^{\dagger}$ & 0.00 & 0.00 & 21.77 & 50.71 & - \\
\hline Irish livestock & 0.00 & 0.00 & 5.30 & 33.84 & - \\
\hline Irish potatoes ${ }^{\ddagger}$ & 0.00 & 0.00 & 19.77 & 0.00 & - \\
\hline Estimate A (Revised) & $2,284.91$ & $2,399.32$ & $2,632.85$ & $2,631.72$ & $2,976.72$ \\
\hline Estimate B (Revised) & $2,284.91$ & $2,614.58$ & $2,595.42$ & $2,666.92$ & $2,976.72$ \\
\hline
\end{tabular}

Notes

The average number of calories derived from grain imports during the period 1841-5 was 140.86 calories.

" In estimating the calorific value of meat imports, we have assumed that $50 \%$ of the imported beef and pork was consumed elsewhere.

+ We have also assumed that the number of calories derived from butter in 1850 was the same as the average figure for the years 1823-5.

* If we had used the recorded data for 1800 , the calorific value of imported potatoes would have been worth 0.01 calories per person per day. If we had used Bourke's figures to calculate the number of calories derived from potatoes in a 'normal' year and applied this figure to 1850 (i.e. ignored the effects of the Famine), the calorific value of potato imports in this year might have been equivalent to approximately 30 calories per person per day.

Sources: See Tables 2, 13, 16, 22-24 and text. 
This article is (c) Emerald Group Publishing and permission has been granted for this version to appear here

(http://strathprints.strath.ac.uk/50435/). Emerald does not grant permission for this article to be further copied/distributed or hosted elsewhere without the express permission from Emerald Group Publishing Limited.

These changes affect Floud et al.'s original estimates in a number of different

ways. The most important single change is the arithmetical correction to the published figures for 1750 . This change raises the previously-published figures by approximately 227 calories in the case of Estimate A and 278 calories in the case of Estimate B. The substitution of Overton and Campbell's extraction rates increases the total number of calories in both 1750 and 1800, and the inclusion of imported Irish foodstuffs raises the figures for 1850. When Floud et al. published their initial figures, they suggested that the total number of calories either fell (Estimate A) or remained largely unchanged (Estimate B) between 1700 and 1750 , but both sets of Estimates suggested that consumption increased between 1750 and 1800 and between 1800 and 1850 . The revised figures suggest that consumption rose between 1700 and 1750 according to both Estimates, but then the two sets of figures diverge. Estimate A suggests that consumption rose substantially between 1750 and 1800 with little change over the next half-century. Estimate B suggests that there was a small reduction in consumption between 1750 and 1800 , followed by a small rise.

The revised figures have implications for two different aspects of Floud et al.'s original argument. In their original study, they argued that the trends in food availability were broadly consistent with the overall pattern of change in both height and mortality (Floud et al., 2011, pp. 162-3). This statement is still true of Estimate A but less so of Estimate B. They also argued that the levels of consumption in the years before 1850 were below the levels needed to ensure that all members of the population could be adequately fed, based on their assessment of the number of calories needed to enable an average-sized adult to perform eight hours of physically-demanding labour (Floud et al., 2011 , pp. 164-9). The new data suggest that this claim may now need to be revised. 
This article is (c) Emerald Group Publishing and permission has been granted for this version to appear here

(http://strathprints.strath.ac.uk/50435/). Emerald does not grant permission for this article to be further copied/distributed or hosted elsewhere without the express permission from Emerald Group Publishing Limited.

We can gain a deeper insight into this question by considering Table 27 . This

table expresses the number of calories available per adult male equivalent, using

Floud et al.'s original conversion factors. The new data suggest that the average number of calories available per adult male equivalent was well below the levels which were likely to have been needed to enable an average-sized man to perform eight hours of physically-demanding labour at the start of the eighteenth century. The calculations derived from Estimate A suggest that this was still true in 1750, but both Estimates suggest that this threshold had been passed by the start of the nineteenth century. However, even if the average number of calories was sufficient to achieve adequacy, it does not follow that all members of the population necessarily had access to the calories they needed. It was only after 1850 that the number of calories began to comfortably exceed the number required for 'heavy work' and this remains significant. ${ }^{7}$

Table 27. Calories per adult male equivalent and requirements for heavy work.

\begin{tabular}{lccccc} 
& 1700 & 1750 & 1800 & 1850 & $1909 / 13$ \\
\hline Estimate A (Revised) & $2,284.91$ & $2,399.32$ & $2,632.85$ & $2,631.72$ & $2,976.72$ \\
Estimate B (Revised) & $2,284.91$ & $2,614.58$ & $2,595.42$ & $2,666.92$ & $2,976.72$ \\
\hline Conversion ratios & 0.7553 & 0.7564 & 0.7506 & 0.7564 & 0.7646 \\
\hline Estimate A (Revised) & $3,025.17$ & $3,172.03$ & $3,507.66$ & $3,479.26$ & $3,893.17$ \\
Estimate B (Revised) & $3,025.17$ & $3,456.61$ & $3,457.79$ & $3,525.80$ & $3,893.17$ \\
\hline Requirement for heavy work & & & $3,376.89$ & $3,470.28$ & $3,433.05$ \\
\hline
\end{tabular}

Sources: Calories per head: see Table 26; Conversion ratios: Floud et al., 2011, p. 167; Requirements for heavy work: Floud et al., 2011 , p. 167.

Although these conclusions have significant implications for Floud et al.'s original arguments, they do little to bridge the gap between Floud et al.'s figures

It is possible that this point may have been reached a little earlier than 1850 , given the reduction in the number of calories obtained from Irish imports during the Famine years. On the other hand, as we have already noted (see footnote 4 ), this takes no account of the dramatic increase in the volume of non-Irish food imports which followed the repeal of the Corn Laws in 1846 (see Mitchell, 1988, p. 225). 
This article is (c) Emerald Group Publishing and permission has been granted for this version to appear here

(http://strathprints.strath.ac.uk/50435/). Emerald does not grant permission for this article to be further copied/distributed or hosted elsewhere without the express permission from Emerald Group Publishing Limited.

and the 'high wage' estimates provided by Allen and Muldrew (see Figure 1 and

Appendix 1). As we have already seen, Allen argued that the number of calories available per head averaged more than 3000 calories per day during the sixteenth, seventeenth and eighteenth centuries and Muldrew claimed that it reached a peak of more than 5000 calories in 1770 . The contrasts with both sets of figures are striking, but it is much easier to compare Floud et al.'s estimates with Muldrew's. This is partly because we have already used some of Allen's figures in the previous section but mainly because Muldrew provided a great deal more information about the foundations on which his figures were built.

Although Muldrew's overall figures were much higher than Floud et al.'s, they were actually based on a somewhat narrower range of comestibles. Muldrew's eighteenth-century consumers derived 29.9 calories from poultry (including chickens, turkeys, geese and ducks) and deer in 1700 and 42.1 calories in 1770 , but they obtained nothing from either potatoes or fish. Using information from Devon in the mid-eighteenth century, he estimated that the average person derived 191.2 calories per day from cider in 1700 , but nothing in 1770 , and he did not include any calories from fruit sources in his final figures (Muldrew, 2011, pp. 1547).

In order to compare Muldrew's estimates directly with those of Floud et al., we can begin by identifying the areas of greatest agreement. Table 28 compares the figures used by the different authors to convert bushels into pounds and to estimate the energy derived from the same amounts of cereals and pulses. It shows that Floud et al. and Muldrew made very similar assumptions about the weight of each bushel and the calorific value of the main cereal crops. However, Muldrew attached a much higher value to the calorific value of beans and peas. If he had used the same conversion factor as Floud et al., the estimated value of the number 
This article is (c) Emerald Group Publishing and permission has been granted for this version to appear here

(http://strathprints.strath.ac.uk/50435/). Emerald does not grant permission for this article to be further copied/distributed or hosted elsewhere without the express permission from Emerald Group Publishing Limited.

of calories derived from these sources would have fallen by 119.64 calories in 1700 ,

137.56 calories in 1770 , and 111.16 calories per person per day in 1800 .

Table 28. Pounds per bushel and calories per pound of cereals and pulses: Muldrew versus Floud et al.

Pounds per bushel

\begin{tabular}{lcccc}
\hline & Floud et al. & Muldrew & Floud et al. & Muldrew \\
\hline Wheat & 57 & 56 & 1,520 & 1,431 \\
Rye & 55 & 56 & 1,520 & 1,508 \\
Barley & 48 & 48 & 1,632 & 1,650 \\
Oats & 38 & 38 & 1,824 & 1,805 \\
Beans and Peas & 56 & 56 & 480 & 1,290 \\
\hline
\end{tabular}

Notes. The calorie figures differ from those published by Kelly and Ó Gráda (2013b, p. 3 [Appendix Table 2]). In his book, Muldrew published different figures for the number of calories per pound of each crop in the text and in Table 3.14 (Muldrew, 2011 , pp. 140-9). The figures in Table 3.14 reflect the number of calories per pound after allowing for milling (so, for example, the number of calories per pound of wheat is given as 1,431 in the text and 1,324 calories in the table). Kelly and Ó Gráda's figures appear to have been derived from the figures in Muldrew's table. However, it is still not clear how they estimated the number of calories per ounce of oats.

Sources: Floud et al., 2011 , pp. 205-7; Muldrew, 2011 , pp. 140-9; Kelly and Ó Gráda, 2013 b, p. 3 (Appendix Table 2).

As we have already seen, Floud et al. generated two different sets of figures for the average productivity of each crop, based on estimates derived from Chartres (1985) and Holderness (1989) in the first instance, and from Chartres, Holderness and Turner et al. (2001) in the second. The differences between the two sets of estimates were minimal in the case of barley, but the figures derived from Chartres and Holderness generated lower estimates for wheat in 1750 and rye in 1800, and for oats in both 1750 and 1800 . On the other hand, they generated higher estimates for the productivity of beans and peas in both years. Muldrew's estimates were based more closely on the figures published by Turner et al., and 
This article is (c) Emerald Group Publishing and permission has been granted for this version to appear here

(http://strathprints.strath.ac.uk/50435/). Emerald does not grant permission for this article to be further copied/distributed or hosted elsewhere without the express permission from Emerald Group Publishing Limited.

this is reflected in Table 29. However, his figures for wheat in 1750 were closer to

Floud et al.'s Estimate A than their Estimate B.

Table 29. Crop yields per acre: Muldrew versus Floud et al.

Floud et al. 2011 (Estimate A) Floud et al. 2011 (Estimate B) Muldrew 2011

\begin{tabular}{lcccccccccccc}
\hline & 1700 & 1750 & 1770 & 1800 & 1700 & 1750 & 1770 & 1800 & 1700 & 1750 & 1770 & 1800 \\
\hline Wheat & 16.0 & 18.0 & 19.4 & 21.5 & 16.0 & 22.0 & 21.6 & 21.1 & 17.0 & 19.1 & 20.0 & 20.5 \\
Rye & 17.0 & 18.0 & 21.2 & 26.0 & 17.0 & 18.0 & 20.2 & 23.4 & 15.0 & 20.0 & 22.0 & 25.5 \\
Barley & 23.0 & 25.0 & 27.0 & 30.0 & 23.0 & 24.8 & 26.6 & 29.2 & 20.0 & 27.1 & 30.0 & 28.0 \\
Oats & 24.0 & 28.0 & 30.8 & 35.0 & 24.0 & 36.7 & 37.0 & 37.4 & 22.0 & 33.4 & 38.0 & 38.0 \\
Beans & & & & & & & & & & & & \\
and Peas & 20.0 & 28.0 & 28.0 & 28.0 & 20.0 & 21.8 & 21.9 & 22.0 & 17.0 & 19.1 & 20.0 & 23.5 \\
\hline
\end{tabular}

Notes. In order to make the two sets of figures more directly comparable, we have interpolated between Floud et al.'s figures for 1750 and 1800 to generate a set of estimates for 1770, and between Muldrew's estimates for 1700 and 1770 to generate an estimate for 1750. Muldrew explained his allowances for seeding in his text, and these have been added to the figures in Table 3.14 of his study to generate the figures for gross yields in this table.

Sources: Floud et al., 2011 , pp. 205-9; Muldrew, 2011, pp. 140-9.

Disagreements over the calorific value of different crops and average yields per acre are much less important than the different authors' attempts to estimate the amount of land under cultivation and the conversion of total yields into edible foodstuffs. In order to estimate the total amount of land under cultivation, it is important to recognise that Muldrew's figures were only partially based on direct information. Although they were derived from Overton's (1996, p. 76) study, Muldrew estimated the total amount of land under cultivation in 1770 by interpolating between Overton's figures for 1700 and 1800 and then reallocated some of the land from barley to wheat in order to generate new figures for each crop (Muldrew, 2011 , pp. 144, 148).

It may also be helpful to compare both sets of estimates with those published by other authors. Although Floud et al.'s figures for the amount of land devoted to wheat are generally towards the lower end of the range of published estimates, their estimate of the total amount of land under cultivation by cereals and pulses 
This article is (c) Emerald Group Publishing and permission has been granted for this version to appear here

(http://strathprints.strath.ac.uk/50435/). Emerald does not grant permission for this article to be further copied/distributed or hosted elsewhere without the express permission from Emerald Group Publishing Limited.

was closer to the centre (see Table 30). By contrast, Muldrew's figures suggest that

the amount of land devoted to wheat in 1770 was 860,000 acres greater than the highest estimate for 1750 , and his figure for 1800 was 130,000 acres greater than the next highest figure for the same year. Overall, he suggested that the amount of land devoted to all cereals and pulses in 1770 was 980,000 acres greater than the highest figure for 1750, and also greater than any of the other published estimates for 1800 . His own figure for 1800 was nearly 1.2 million acres higher than the next published figure.

Muldrew's figures also raise three further questions. As we have already seen, Muldrew derived his figures for the total amount of land under cultivation from Overton's 1996 study. However, although Overton (1996, p. 76) argued that these figures applied to the whole of England and Wales, Muldrew (2011, pp. 142-3) appears to have divided the total amount of food produced from this land among the population of England alone. The second problem is that Overton himself argued that these figures had been superseded by the work he published with Bruce Campbell in the same year (Overton and Campbell, 1996, pp. 282; 2006, p. 29). The third problem is that Muldrew also assumed that the total amount of land under cultivation grew at a consistent rate between 1700 and 1800 , but this assumption is called into question by the figures which Overton published with Broadberry, Campbell, Klein and van Leeuwen (Broadberry et al., 2011, p. 36). As we can see from Table 30, these figures imply that the total amount of land devoted to the cultivation of cereals and pulses fell from 6.36 million acres in 1700 to 6.31 million acres in 1750 . The amount of land associated with the cultivation of wheat fell, according to their calculations, from 1.99 million acres to 1.95 , whereas Muldrew's calculations imply that it increased from 1.6 million acres to 2.57 million acres over the same period (see Table 31 ). 
This article is (c) Emerald Group Publishing and permission has been granted for this version to appear here

(http://strathprints.strath.ac.uk/50435/). Emerald does not grant permission for this article to be further copied/distributed or hosted elsewhere without the express permission from Emerald Group Publishing Limited.

Table 30. Land under cultivation: Muldrew versus Floud et al. (millions of acres)

\begin{tabular}{lcccccccc} 
& \multicolumn{9}{c}{ Floud et al. 2011} & \multicolumn{5}{c}{ Muldrew 2011} \\
\hline Wheat & 1700 & 1750 & 1770 & 1800 & 1700 & 1750 & 1770 & 1800 \\
Rye & 1.361 & 1.800 & 2.080 & 2.500 & 1.600 & 2.569 & 2.957 & 3.104 \\
Barley & 0.890 & 0.500 & 0.420 & 0.300 & 0.520 & 0.602 & 0.635 & 0.097 \\
Oats & 1.901 & 1.400 & 1.360 & 1.300 & 2.040 & 1.935 & 1.892 & 1.843 \\
Beans and & 1.223 & 2.000 & 2.000 & 2.000 & 1.060 & 1.228 & 2.522 & 2.522 \\
Peas & 1.300 & 1.000 & 1.080 & 1.000 & 0.980 & 1.135 & 1.198 & 1.067 \\
\hline Total & 6.675 & 6.700 & 6.940 & 7.300 & 6.200 & 7.470 & 7.978 & 8.633 \\
\hline
\end{tabular}

Notes. For the methods used to calculate values for Floud et al. in 1770 and Muldrew in 1750, see Table 20. Sources: Floud et al., 2011 , pp. 205-7; Muldrew, 2011, pp. 142-3.

The second major cause of variation lies in the different assumptions which Floud et al. and Muldrew made when they converted the original crop into edible food. This can involve up to four separate calculations, taking account of the amount of grain used for seed, the proportion used as animal feed, processing, and distribution and wastage.

As we have already seen, Floud et al. (2011, p. 154) did not distinguish between the amount of grain used for seed and the amount fed to animals when they calculated the proportion of cereals and pulses entering gross product. However, they assumed implicitly that this figure was a constant proportion of the gross yield. By contrast, most other authors have assumed that the amount used as seed was a constant or even declining figure (see e.g. Allen, 2005, p. 34; Overton and Campbell, 1996, pp. 292-5; 2006, pp. 37-44), and that the proportion of each grain which was used as seed also declined as productivity increased. This explains why Muldrew's figures show that the proportion of each crop which remained after seeding increased over the course of the period (Table 32). 


\begin{tabular}{|c|c|c|c|c|c|c|c|c|c|c|c|c|c|c|c|}
\hline & $\cdots$ & \multicolumn{6}{|c|}{ Cereals and pulses } & \multicolumn{5}{|c|}{ Other crops } & \multirow[b]{2}{*}{$\begin{array}{l}\text { Total } \\
\text { sown } \\
\text { area }\end{array}$} & \multirow{2}{*}{$\begin{array}{c}\text { Fallow/ } \\
\text { unsow } \\
n\end{array}$} & \multirow[t]{2}{*}{ Total } \\
\hline & & Wheat & Rye & Barley & Oats & $\begin{array}{l}\text { Beans/ } \\
\text { Peas/ } \\
\text { Pulses }\end{array}$ & $\begin{array}{c}\text { Total } \\
\text { cereal } \\
\text { and } \\
\text { pulses }\end{array}$ & Turnips & $\begin{array}{l}\text { Potatoe } \\
\text { s }\end{array}$ & $\begin{array}{l}\text { Clover } \\
\text { etc. }\end{array}$ & $\begin{array}{l}\text { Other } \\
\text { crops }\end{array}$ & $\begin{array}{l}\text { Total } \\
\text { other } \\
\text { crops }\end{array}$ & & & \\
\hline 1270 & Broadberry et al., 2011 , p. $36^{\circ}$ & 2.21 & 0.72 & 1.23 & 2.94 & 0.29 & 7.39 & - & 0.00 & - & 0.00 & 0.00 & 7.39 & 5.13 & 12.52 \\
\hline 1300 & Allen, 2005, p. 28 & 2.70 & 0.60 & 1.50 & 2.70 & 0.60 & 8.10 & 0.00 & 0.00 & 0.00 & - & 0.00 & 8.10 & 4.00 & 12.10 \\
\hline 1300 & Broadberry et al., 2011 , p. $36^{\circ}$ & 2.68 & 0.60 & 1.27 & 3.16 & 0.45 & 8.16 & - & 0.00 & - & 0.00 & 0.00 & 8.16 & 4.56 & 12.72 \\
\hline 1300 & Overton and Campbell, 1996, Table 5 & 2.28 & 0.47 & 1.24 & 2.24 & 0.53 & 6.76 & 0.00 & 0.00 & 0.00 & 0.00 & 0.00 & 6.76 & 3.77 & 10.53 \\
\hline 1380 & Broadberry et al., 2011, p. $36^{\circ}$ & 1.83 & 0.36 & 1.22 & 1.87 & 0.47 & 5.75 & - & 0.00 & - & 0.00 & 0.00 & 5.75 & 3.89 & 9.64 \\
\hline 1380 & Overton and Campbell, 1996, Table $5^{*}$ & 1.49 & 0.16 & 1.26 & 1.10 & 0.69 & 4.70 & 0.00 & 0.00 & 0.00 & 0.00 & 0.00 & 4.70 & 3.22 & 7.92 \\
\hline 1420 & Broadberry et al., 2011, p. $36^{\circ}$ & 1.61 & 0.32 & 1.17 & 1.66 & 0.45 & 5.21 & - & 0.00 & - & 0.00 & 0.00 & 5.21 & 3.53 & 8.74 \\
\hline 1450 & Broadberry et al., 2011 , p. $36^{\circ}$ & 1.53 & 0.31 & 1.15 & 1.59 & 0.44 & 5.02 & - & 0.00 & - & 0.00 & 0.00 & 5.02 & 3.41 & 8.43 \\
\hline 1500 & Allen, 2005, p. 28 & 1.80 & 0.20 & 1.50 & 1.30 & 1.20 & 6.00 & 0.00 & 0.00 & 0.00 & - & 0.00 & 6.00 & 3.00 & 9.00 \\
\hline 1500 & Broadberry et al., 2011 , p. 36 & 1.58 & 0.37 & 1.19 & 1.56 & 0.47 & 5.17 & - & 0.00 & - & 0.10 & 0.10 & 5.27 & 3.24 & 8.51 \\
\hline 1600 & Broadberry et al., 2011 , p. 36 & 1.85 & 0.77 & 1.44 & 1.32 & 0.61 & 5.99 & - & 0.00 & - & 0.72 & 0.72 & 6.71 & 2.16 & 8.87 \\
\hline 1600 & Muldrew, 2011, p. $143^{*}$ & 1.53 & 0.47 & 1.78 & 0.89 & 0.83 & 5.50 & - & - & - & 0.50 & 0.50 & 6.00 & 2.00 & 8.00 \\
\hline 1600 & Overton and Campbell, 1996, Table $5^{*}$ & 1.56 & 0.47 & 1.78 & 0.89 & 0.83 & 5.53 & 0.00 & 0.00 & 0.00 & 0.70 & 0.70 & 6.23 & 2.00 & 8.23 \\
\hline 1650 & Broadberry et al., 2011 , p. $36^{*}$ & 2.00 & 0.39 & 1.86 & 1.13 & 1.02 & 6.40 & - & 0.00 & - & 1.36 & 1.36 & 7.76 & 1.88 & 9.64 \\
\hline 1650 & Muldrew, 2011, p. $143^{\prime \prime}$ & 1.60 & 0.52 & 2.04 & 1.06 & 0.98 & 6.20 & - & - & - & 1.00 & 1.00 & 7.20 & 1.80 & 9.00 \\
\hline 1695 & Chartres, 1985, p. 444 & 1.36 & 0.89 & 1.90 & 1.22 & - & 5.38 & - & - & - & - & - & - & - & - \\
\hline 1700 & Allen, 2005, p. 28 & 1.40 & 0.90 & 1.90 & 1.20 & 1.30 & 6.70 & 0.40 & 0.10 & 0.50 & - & 1.00 & 7.70 & 3.30 & 11.00 \\
\hline 1700 & Broadberry et al., 2011 , p. $36^{\circ}$ & 1.99 & 0.42 & 1.82 & 1.15 & 0.98 & 6.36 & - & 0.00 & - & 1.30 & 1.30 & 7.66 & 1.91 & 9.57 \\
\hline 1700 & Muldrew, 2011 , p. $143^{\circ}$ & 1.60 & 0.52 & 2.04 & 1.06 & 0.98 & 6.20 & - & - & - & 1.00 & 1.00 & 7.20 & 1.80 & 9.00 \\
\hline 1700 & Overton, 1996, p. 76 & - & - & - & - & - & - & - & - & - & - & - & 7.20 & 1.80 & 9.00 \\
\hline 1700 & Overton and Campbell, 1996, Table 5 & 1.60 & 0.52 & 2.04 & 1.06 & 0.98 & 6.20 & 0.00 & 0.00 & 0.00 & 1.00 & 1.00 & 7.20 & 1.80 & 9.00 \\
\hline 1750 & Allen, 2005, p. 28 & 2.10 & 0.50 & 1.70 & 1.40 & 1.30 & 7.00 & 0.75 & 0.20 & 0.75 & - & 1.70 & 8.70 & 2.50 & 11.20 \\
\hline 1750 & Broadberry et al., 2011, p. $36^{\circ}$ & 1.95 & 0.06 & 1.50 & 1.82 & 0.98 & 6.31 & - & 0.08 & - & 2.53 & 2.61 & 8.92 & 1.59 & 10.51 \\
\hline 1750 & Chartres, 1985, p. 444 & 2.10 & 0.53 & 1.66 & 1.44 & - & 5.73 & - & - & - & - & - & - & - & - \\
\hline 1750 & Holderness, 1985, p. 145 & 1.80 & 0.50 & 1.40 & 2.00 & 1.00 & 6.70 & 1.00 & 0.20 & 1.00 & - & 2.20 & 8.90 & - & - \\
\hline 1770 & Muldrew, 2011, p. 143" & 2.96 & 0.64 & 1.89 & 1.30 & 1.20 & 7.98 & - & - & - & 1.22 & 1.22 & 9.20 & 1.80 & 11.00 \\
\hline 1770 & $\begin{array}{l}\text { Young, } 1771 \text { b, pp. 256-61 (Prince, } \\
\text { 1989, p. 31) }\end{array}$ & - & - & - & - & - & - & - & - & - & - & - & 10.30 & - & 10.30 \\
\hline 1770 & $\begin{array}{l}\text { Young, } 1771 \text { b, pp. 256-61 John, 1989, } \\
\text { p. 1045) }\end{array}$ & 2.80 & - & 2.60 & 1.50 & 0.9 & 7.80 & 1.70 & - & 3.20 & - & 4.90 & 12.70 & 0.80 & 13.50 \\
\hline
\end{tabular}


This article is $\odot$ Emerald Group Publishing and permission has been granted for this version to appear here (http://strathprints.strath.ac.uk/50435/). Emerald does not grant permission for this article to be further copied/distributed or hosted elsewhere without the express permission from Emerald Croup Publishing Limited.

\begin{tabular}{|c|c|c|c|c|c|c|c|c|c|c|c|c|c|c|c|}
\hline 1800 & Allen, 2005, p. 28 & 2.50 & 0.30 & 1.30 & 2.00 & 1.20 & 7.30 & 1.30 & 0.30 & 1.20 & - & 2.80 & 10.10 & 1.50 & 11.60 \\
\hline 1800 & Broadberry et al., 2011 , p. $36^{\circ}$ & 2.97 & 0.06 & 1.62 & 1.97 & 0.83 & 7.45 & - & 0.17 & - & 2.90 & 3.07 & 10.52 & 1.28 & 11.80 \\
\hline 1800 & Holderness, 1985 , p. 145 & 2.50 & 0.30 & 1.30 & 2.00 & 1.20 & 7.30 & 1.30 & 0.30 & 1.20 & - & 2.80 & 10.10 & - & 10.10 \\
\hline 1800 & Muldrew, 2011, p. $143^{\circ}$ & 3.10 & 0.10 & 1.84 & 2.52 & 1.07 & 8.63 & - & - & - & 1.07 & 1.07 & 9.70 & 1.80 & 11.50 \\
\hline 1800 & Overton 1996, p. 76 & - & - & - & - & - & - & - & - & - & - & - & 9.70 & 1.80 & 11.50 \\
\hline 1800 & Overton and Campbell, 1996, Table 5* & 2.44 & 0.06 & 1.38 & 1.93 & 0.78 & 6.59 & 0.68 & 0.16 & 1.20 & 0.86 & 2.90 & 9.49 & 1.20 & 10.69 \\
\hline 1801 & Capper, 1801 (Prince, 1989, p. 31) & - & - & - & - & - & - & - & - & - & - & - & 11.35 & - & - \\
\hline 1801 & $\begin{array}{l}\text { Turner 1981 A (Turner, 1981, pp. 295- } \\
\text { 301) }\end{array}$ & 2.25 & 0.06 & 1.38 & 1.91 & 0.70 & 6.31 & 0.60 & 0.16 & - & 0.01 & 0.77 & 7.08 & - & - \\
\hline 1801 & $\begin{array}{l}\text { Turner } 1981 \text { B (Turner, 1981, pp. 295- } \\
\text { 301) }\end{array}$ & 2.50 & 0.07 & 1.53 & 2.12 & 0.78 & 7.01 & 0.67 & 0.17 & - & 0.01 & 0.85 & 7.86 & - & - \\
\hline 1808 & Comber, 1808 (Prince, 1989, p. 31) & - & - & - & - & - & - & - & - & - & - & & 11.58 & - & - \\
\hline 1810 & Holderness, 1985 , p. 145 & 2.90 & 0.10 & 1.30 & 2.10 & 1.20 & 7.60 & 1.60 & 0.40 & 1.70 & - & 3.70 & 11.30 & - & - \\
\hline 1827 & $\begin{array}{l}\text { Parliamentary Papers, 1827, Tables } \\
\text { 359-61 (Prince, 1989, p. 31) }\end{array}$ & - & - & - & - & - & - & - & - & - & - & - & 11.14 & - & - \\
\hline 1830 & Broadberry et al., 2011, p. 36 & 2.08 & 0.06 & 1.82 & 1.39 & 0.63 & 5.98 & - & 0.26 & - & 4.46 & 4.72 & 10.70 & 1.30 & 12.00 \\
\hline 1830 & Overton and Campbell, 1996, Table 5* & 3.40 & 0.06 & 2.00 & 1.60 & 0.60 & 7.66 & 1.44 & 0.29 & 2.89 & 0.58 & 5.20 & 12.86 & 1.33 & 14.19 \\
\hline 1836 & $\begin{array}{l}\text { Kain, 1986, p. } 460 \text { (Prince, 1989, p. } \\
41)^{\circ}\end{array}$ & 3.40 & - & 2.00 & 1.60 & 0.60 & 7.60 & 1.30 & - & - & - & - & - & - & - \\
\hline 1836 & $\begin{array}{l}\text { Kain and Prince, 1985, p. } 104 \text { (Prince } \\
1989, \text { p. } 31 \text { ) }\end{array}$ & - & - & - & - & - & - & - & - & - & - & - & 15.09 & - & 15.09 \\
\hline 1850 & Allen, 2005, p. 28 & 3.60 & 0.10 & 1.50 & 2.00 & 1.00 & 8.20 & 2.00 & 0.40 & 2.20 & - & 4.60 & 12.80 & 1.80 & 14.60 \\
\hline 1850 & Holderness, 1985, p. 145 & 3.60 & 0.10 & 1.50 & 2.00 & 1.00 & 8.20 & 2.00 & 0.40 & 2.20 & - & 4.60 & 12.80 & - & - \\
\hline 1850 & Overton, 1996, p. 76 & - & - & - & - & - & - & - & - & - & - & - & 14.30 & 1.00 & 15.30 \\
\hline 1851 & $\begin{array}{l}\text { Caird, 1852, p. } 522 \text { (Prince 1989, p. } \\
\text { 31) }\end{array}$ & - & - & - & - & - & - & - & - & - & - & - & 13.67 & - & - \\
\hline 1854 & $\begin{array}{l}\text { Parliamentary Papers, } 1854, \text { p. } 495 \\
\text { (Prince 1989, p. } 31 \text { ) }\end{array}$ & - & - & - & - & - & - & - & - & - & - & - & & - & 15.26 \\
\hline 1854 & $\begin{array}{l}\text { Parliamentary Papers, } 1854 \text {, p. } 495 \\
\text { (Prince, 1989, p. 41) }\end{array}$ & 3.80 & - & 2.70 & 1.30 & 0.70 & 8.50 & 2.30 & - & - & - & - & - & - & - \\
\hline 1854 & $\begin{array}{l}\text { Parliamentary Papers, 1854, p. } 495 \\
\text { (John, 1989, p. 1042) }\end{array}$ & 3.81 & 0.02 & 2.67 & 1.30 & 0.70 & 8.50 & 2.27 & 0.19 & 2.82 & 0.54 & 3.00 & 11.55 & 0.90 & 15.26 \\
\hline 1871 & Broadberry et al., 2011 , p. 36 & 3.31 & 0.06 & 1.96 & 1.45 & 0.90 & 7.68 & - & 0.39 & - & 5.28 & 5.67 & 13.35 & 0.48 & 13.83 \\
\hline 1871 & Overton, 1996, p. 76 & - & - & - & - & - & - & - & - & - & - & - & 14.40 & 0.50 & 14.90 \\
\hline 1871 & Overton and Campbell, 1996, Table 5* & 3.32 & 0.06 & 1.96 & 1.45 & 0.90 & 7.69 & 2.14 & 0.39 & 3.06 & 0.08 & 5.67 & 13.36 & 0.48 & 13.84 \\
\hline
\end{tabular}

Notes: Floud et al.'s figures were derived from Chartres (for 1695/1700) and Holderness (1750-1850). For 1380, Overton and Campbell's figures sum to 7.92 acres (shown here) but their published figure was 7.98. They estimated the amount of land under cultivation by each crop in 1600 and 1700 by extrapolating their results for Cornwall, Hampshire, Kent, Lincolnshire, Norfolk, Suffolk and

Worcestershire. Young's (1770) figure for the amount of fallow land ( 0.8 million acres) included 'other crops'. Kain's (1986) figures for 1836 and the Parliamentary figures for 1854 aggregate the amount of land under cultivation by wheat and and rye. Asterisked publications refer to England only; all other publications refer to England and Wales as a whole. 
This article is $\odot$ Emerald Group Publishing and permission has been granted for this version to appear here (http://strathprints.strath.ac.uk/50435/). Emerald does not grant permission for this article to be further copied/distributed or hosted elsewhere without the express permission from Emerald Group Publishing Limited.

Sources: See Table. 
This article is $\odot$ Emerald Group Publishing and permission has been granted for this version to appear here (http://strathprints.strath.ac.uk/50435/). Emerald does not grant permission for this article to be further copied/distributed or hosted elsewhere without the express permission from Emerald Croup Publishing Limited.

Table 32. Calories from global crop production: Muldrew's figures, using Floud et al.'s format

\begin{tabular}{|c|c|c|c|c|c|c|c|c|c|c|c|c|c|c|c|c|}
\hline & & $\begin{array}{l}\text { Millions } \\
\text { of acres }\end{array}$ & $\begin{array}{l}\text { Yields } \\
\text { per } \\
\text { acre } \\
\text { (gross) }\end{array}$ & $\begin{array}{l}\text { Gross } \\
\text { output }\end{array}$ & $\begin{array}{l}\text { Yields } \\
\text { per } \\
\text { acre } \\
\text { (net of } \\
\text { seed) }\end{array}$ & $\begin{array}{l}\text { Proportion } \\
\text { fed to } \\
\text { livestock }\end{array}$ & $\begin{array}{c}\% \\
\text { entering } \\
\text { gross } \\
\text { product }\end{array}$ & $\begin{array}{l}\text { Millions } \\
\text { of } \\
\text { bushels } \\
\text { as food }\end{array}$ & $\begin{array}{l}\text { Lbs } \\
\text { per } \\
\text { bushel }\end{array}$ & $\begin{array}{l}\text { Lbs of } \\
\text { food }\end{array}$ & $\begin{array}{l}\text { kCal } \\
\text { per lb }\end{array}$ & $\begin{array}{l}\text { Proportion } \\
\text { net of } \\
\text { milling and } \\
\text { distribution } \\
\text { losses }\end{array}$ & $\begin{array}{l}\text { Total kCal } \\
\text { net of } \\
\text { milling and } \\
\text { distribution } \\
\text { losses } \\
(000,000 \mathrm{~s})\end{array}$ & $\begin{array}{l}\text { Population } \\
\text { (England } \\
\text { and } \\
\text { Wales) }\end{array}$ & $\begin{array}{c}\text { Kcal per cap. } \\
\text { Available for } \\
\text { consumption } \\
\text { per day }\end{array}$ & $\begin{array}{l}\text { Muldrew } \\
\text { (published } \\
\text { totals) }\end{array}$ \\
\hline & & (1) & (2) & (3) & $(4 \mathrm{~A})$ & (4B) & (4C) & (5) & (6) & (7) & (8) & (9) & (10) & (11) & (12) & (13) \\
\hline & & & & & & & & $(3) *(4 C)$ & & $(5) *(6)$ & & & $(7) *(8) *(9)$ & & $(10) /(11)$ & \\
\hline \multirow[t]{6}{*}{1700} & Wheat & 1.60000 & 17.0 & 27.2 & 14.5 & 0.0 & 0.853 & 23.2 & 56 & 1,299 & 1,431 & 0.9250 & $1,719,719$ & $4,896,666$ & 962.20 & 965 \\
\hline & Rye & 0.52000 & 15.0 & 7.8 & 12.5 & 0.0 & 0.833 & 6.5 & 56 & 364 & 1,508 & 0.9250 & 507,744 & 4,896,666 & 284.09 & 285 \\
\hline & Barley & 2.04000 & 20.0 & 40.8 & 16.0 & 0.0 & 0.800 & 32.6 & 48 & 1,567 & 1,650 & 0.7300 & $1,887,114$ & $4,896,666$ & $1,055.86$ & 1,060 \\
\hline & Oats & 1.06000 & 22.0 & 23.3 & 16.0 & 0.5 & 0.364 & 8.5 & 38 & 322 & 1,805 & 0.5550 & 322,812 & $4,896,666$ & 180.62 & 181 \\
\hline & Beans \& peas & 0.98000 & 17.0 & 16.7 & 13.0 & 0.6 & 0.306 & 5.1 & 56 & 285 & 1,290 & 0.9250 & 340,525 & $4,896,666$ & 190.53 & 191 \\
\hline & Total & & & & & & & & & & & & & & $2,673.28$ & 2,682 \\
\hline \multirow[t]{6}{*}{1770} & Wheat & 2.95720 & 20.0 & 59.1 & 17.5 & 0.0 & 0.875 & 51.8 & 56 & 2,898 & 1,431 & 0.9250 & $3,836,084$ & $6,405,166$ & $1,640.83$ & 1,646 \\
\hline & Rye & 0.63544 & 22.0 & 14.0 & 19.5 & 0.0 & 0.886 & 12.4 & 56 & 694 & 1,508 & 0.9250 & 967,922 & $6,405,166$ & 414.02 & 415 \\
\hline & Barley & 1.89248 & 30.0 & 56.8 & 26.0 & 0.0 & 0.867 & 49.2 & 48 & 2,362 & 1,650 & 0.7300 & $2,844,806$ & $6,405,166$ & $1,216.83$ & 1,222 \\
\hline & Oats & 1.29532 & 38.0 & 49.2 & 32.0 & 0.3 & 0.603 & 29.7 & 38 & 1,127 & 1,805 & 0.5550 & $1,129,196$ & $6,405,166$ & 483.00 & 483 \\
\hline & Beans \& peas & 1.19756 & 20.0 & 24.0 & 16.0 & 0.6 & 0.320 & 7.7 & 56 & 429 & 1,290 & 0.9250 & 512,149 & $6,405,166$ & 219.07 & 220 \\
\hline & Total & & & & & & & & & & & & & & $3,973.74$ & 3,986 \\
\hline \multirow[t]{6}{*}{1800} & Wheat & 3.10400 & 20.5 & 63.6 & 18.0 & 0.0 & 0.878 & 55.9 & 56 & 3,129 & 1,431 & 0.9250 & $4,141,557$ & $8,606,033$ & $1,318.46$ & 1,322 \\
\hline & Rye & 0.09700 & 25.5 & 2.5 & 23.0 & 0.0 & 0.902 & 2.2 & 56 & 125 & 1,508 & 0.9250 & 174,273 & $8,606,033$ & 55.48 & 56 \\
\hline & Barley & 1.84300 & 28.0 & 51.6 & 24.0 & 0.0 & 0.857 & 44.2 & 48 & 2,123 & 1,650 & 0.7300 & $2,557,317$ & $8,606,033$ & 814.12 & 817 \\
\hline & Oats & 2.52200 & 38.0 & 95.8 & 32.0 & 0.2 & 0.703 & 67.3 & 38 & 2,559 & 1,805 & 0.5550 & $2,563,226$ & $8,606,033$ & 816.00 & 816 \\
\hline & Beans \& peas & 1.06700 & 23.5 & 25.1 & 19.5 & 0.6 & 0.332 & 8.3 & 56 & 466 & 1,290 & 0.9250 & 556,133 & $8,606,033$ & 177.04 & 177 \\
\hline & Total & & & & & & & & & & & & & & $3,181.11$ & 3,188 \\
\hline
\end{tabular}

Notes. Figures showing the gross yield per acre, proportions fed to livestock and allowances for processing and wastage have been derived from the text. All other figures are derived from Table 3.14 of Muldrew's study. The figures in column 12 differ from the published figures in column 13 as a result of rounding.

Source: Muldrew, 2011 , pp. 140-9. 
This article is (c) Emerald Group Publishing and permission has been granted for this version to appear here

(http://strathprints.strath.ac.uk/50435/). Emerald does not grant permission for this article to be further copied/distributed or hosted elsewhere without the express permission from Emerald Group Publishing Limited.

Table 32 also enables us to see the amount of grain which Muldrew allocated

to animals. He assumed that the only crops fed to animals were oats, beans and

peas. However, in contrast to Overton and Campbell (1996, pp. 292-5; 2006, pp.

37-44), he also assumed that the proportion of the oat crop which was fed to

animals declined over the course of the century, with the result that a much higher proportion of the original crop remained available for human consumption. On the other hand, he also assumed that animals consumed a higher proportion of beans and peas.

One of the most important areas of disagreement concerns the amount of crop lost as a result of processing and wastage. Muldrew (2011, pp. 146-7) assumed that none of the wheat, rye or beans and peas was lost as a result of processing and that, after making allowances for seeding, only 7.5 per cent of the remaining crop was lost as a result of wastage (primarily, as a result of mice and mould). He argued that a similar proportion of the barley and oat crop was also wasted, but that these losses were augmented by the effects of processing. He assumed that forty per cent of the raw oat crop was lost in the process of converting it to oatmeal, which brought his final figure much closer to Floud et al.'s, but that only twenty per cent of barley was lost in this way. In contrast to Overton and Campbell (1996, pp. 292-5; 2006, pp. 37-44), he also assumed that the proportion of barley brewed as beer remained constant over the course of the century, whereas they assumed that it increased.

Muldrew also reached different conclusions about the number of calories derived from meat and, especially, dairy products. Although he estimated that the calorific value of the meat derived from cattle, sheep and pigs was generally lower than Floud et al., he also assumed that the number of animals was much larger. However, in comparison with the estimated value of the food consumed from other 
This article is (c) Emerald Group Publishing and permission has been granted for this version to appear here

(http://strathprints.strath.ac.uk/50435/). Emerald does not grant permission for this article to be further copied/distributed or hosted elsewhere without the express permission from Emerald Group Publishing Limited.

sources, the differences were not very large. If we bear in mind that our figures for

Muldrew in 1750 and for Floud et al. in 1770 have been interpolated from other data, then the information in Table 32 implies that Muldrew's consumers derived substantially more calories from meat in 1700 and 1770 , but similar amounts in 1750 and 1800.

These differences are less marked, and less systematic, than the differences in the numbers of calories derived from dairy products. Floud et al. derived their estimates of the number of calories obtained from milk, butter and cheese in 1750 , 1800 and 1850 from Holderness (1989, p. 170) and estimated the number of dairy calories in 1700 from the ratio of meat products to dairy products in 1750 .

Muldrew estimated the total number of milk cows in 1700 using information from Gregory King (1696) and then assumed that the number did not change for the rest of the century. However, he did assume that the average yield per cow increased by 25 per cent between 1700 and 1770 . He did not attempt to distinguish between calories consumed as milk and calories consumed as cheese or butter, but he did assume that 20 per cent of all calories were 'lost' in the form of animal feed.

It is difficult to compare the two sets of figures directly because Floud et al. only offered detailed breakdowns of their figures for 1750, 1800 and 1850, and Muldrew only provided detailed figures for 1700 and 1770, although we can infer the nature of his calculations for 1800 from this. However, Table 34 suggests that the two sets of figures differ mainly because of assumptions about the number of animals producing dairy products. Although King (1696, p. 54) estimated the overall number of 'beeves, sterks and calves' as 4.5 million, he did not attempt to break the figures down further, and Muldrew's suggestion of 1.1 million milk cows must therefore be regarded as conjecture. Both King's figures and Muldrew's can also be contrasted with the figures suggested by Arthur Young in 1771 and by the 
This article is (c) Emerald Group Publishing and permission has been granted for this version to appear here

(http://strathprints.strath.ac.uk/50435/). Emerald does not grant permission for this article to be further copied/distributed or hosted elsewhere without the express permission from Emerald Group Publishing Limited.

Poor Law Inspectors in 1854. Young (1771b, pp. 256-61) estimated that there were

741,532 milk cows in the whole of England and Wales in 1770, and A.H. John's

(1989, p. 1044) calculations suggest that this figure had only risen to 1.38 million more than eighty years later.

\section{The search for compromise}

The number and variety of the estimates offered by different authors has encouraged others to enter the field. Kelly and Ó Gráda have contrasted Broadberry et al.'s estimates with Muldrew's and suggested alternatives to both. However, some of their revisions are fairly approximate and they still leave a large gap between the two series (Kelly and Ó Gráda 2013b. p. 3 [Appendix Table 3]; see also Appendix 1 below). Meredith and Oxley's (2014) project was more ambitious. They contrasted Muldrew's estimates with those of Floud et al. and also examined the effect of applying the different authors' assumptions to each other's data. This enabled them to recalculate Muldrew's figures by using Floud et al.'s assumptions about seeding, animal consumption, processing and wastage, and adding the resulting estimates to Muldrew's own figures for the number of calories obtained from meat and dairy products. They then combined these figures with Floud et al.'s data for imports and exports in 1700 and 1800 to produce a new series of total calories available per person per day net of trade, and used Floud et al.'s data for 1850 and $1909 / 13$ to extend this series to the start of the First World War. 
This article is @ Emerald Group Publishing and permission has been granted for this version to appear here (http://strathprints.strath.ac.uk/50435/). Emerald does not grant permission for this article to be further copied/distributed or hosted elsewhere without the express permission from Emerald Group Publishing Limited.

Table 33. Meat consumption: Muldrew versus Floud et al.

1695 (1700)

\begin{tabular}{|c|c|c|c|c|c|c|c|c|c|c|}
\hline & \multicolumn{5}{|c|}{ Muldrew 2011} & \multicolumn{5}{|c|}{ Floud et al. 2011} \\
\hline & $\begin{array}{l}\text { Total weight of } \\
\text { consumption } \\
\text { (lbs) }\end{array}$ & Population & $\begin{array}{c}\text { Pounds per } \\
\text { person per } \\
\text { day } \\
\text { (calculated) }\end{array}$ & $\begin{array}{l}\text { Calories } \\
\text { per } \\
\text { pound }\end{array}$ & $\begin{array}{c}\text { Calories per } \\
\text { day } \\
\text { (calculated) }\end{array}$ & $\begin{array}{l}\text { Total weight of } \\
\text { consumption } \\
\text { (Ibs) }\end{array}$ & Population & $\begin{array}{c}\text { Pounds per } \\
\text { person per } \\
\text { day } \\
\text { (calculated) }\end{array}$ & $\begin{array}{l}\text { Calories } \\
\text { per } \\
\text { pound }\end{array}$ & $\begin{array}{c}\text { Calories per } \\
\text { day } \\
\text { (calculated) }\end{array}$ \\
\hline Beef and veal" & $280,000,000$ & $4,896,666$ & 0.1567 & 1,000 & 156.7 & $208,000,000$ & $5,444,426$ & 0.1047 & 1,318 & 137.98 \\
\hline Sheep & $200,000,000$ & $4,896,666$ & 0.1119 & 1,000 & 111.9 & $102,400,000$ & $5,444,426$ & 0.0515 & 1,472 & 75.86 \\
\hline Swine $^{t}$ & $200,000,000$ & $4,896,666$ & 0.1119 & 1,114 & 124.7 & $70,638,750$ & $5,444,426$ & 0.0355 & 2,348 & 83.46 \\
\hline Others $^{\ddagger}$ & $50,400,000$ & $4,896,666$ & 0.0282 & 1,026 & 28.9 & $27,890,000$ & $5,444,426$ & 0.0140 & 687 & 9.65 \\
\hline \multirow[t]{4}{*}{ Total $^{* * *}$} & $1,010,400,000$ & $4,896,666$ & 0.4087 & - & 422.1 & $47,020,000$ & $5,444,426$ & 0.0237 & - & 306.94 \\
\hline & \multicolumn{10}{|c|}{1750} \\
\hline & \multicolumn{5}{|c|}{ Muldrew 201 1: 142-3 (interpolated) } & \multicolumn{5}{|c|}{ Floud et al. 2011: 210-11 } \\
\hline & $\begin{array}{l}\text { Total weight of } \\
\text { consumption } \\
\text { (lbs) }\end{array}$ & Population & $\begin{array}{l}\text { Pounds per } \\
\text { person per } \\
\text { day } \\
\text { (calculated) }\end{array}$ & $\begin{array}{l}\text { Calories } \\
\text { per } \\
\text { pound }\end{array}$ & $\begin{array}{c}\text { Calories per } \\
\text { day } \\
\text { (calculated) }\end{array}$ & $\begin{array}{l}\text { Total weight of } \\
\text { consumption } \\
\text { (Ibs) }\end{array}$ & Population & $\begin{array}{l}\text { Pounds per } \\
\text { person per } \\
\text { day } \\
\text { (calculated) }\end{array}$ & $\begin{array}{l}\text { Calories } \\
\text { per } \\
\text { pound }\end{array}$ & $\begin{array}{c}\text { Calories per } \\
\text { day } \\
\text { (calculated) }\end{array}$ \\
\hline Beef and veal" & $367,857,143$ & $5,974,166$ & 0.1679 & 1,071 & 179 & $285,600,000$ & $6,192,091$ & 0.1264 & 1,318 & 166.58 \\
\hline Sheep & $381,600,000$ & $5,974,166$ & 0.1708 & 1,071 & 185 & $217,280,000$ & $6,192,091$ & 0.0961 & 1,472 & 141.53 \\
\hline Swine $^{\dagger}$ & $242,857,143$ & $5,974,166$ & 0.1114 & 1,185 & 132 & $191,835,000$ & $6,192,091$ & 0.0849 & 2,348 & 199.27 \\
\hline Others $^{\ddagger}$ & $84,114,286$ & $5,974,166$ & 0.0379 & 293 & 38 & - & $6,192,091$ & - & 687 & 0.00 \\
\hline \multirow[t]{2}{*}{ Total $^{* *}$} & $1,444,285,714$ & $5,974,166$ & 0.4879 & 0 & 534 & $47,020,000$ & $6,192,091$ & - & - & 507.38 \\
\hline & \multicolumn{10}{|c|}{1770} \\
\hline
\end{tabular}

Forthcoming in Research in Economic History, 31 (2015) 
This article is $\odot$ Emerald Group Publishing and permission has been granted for this version to appear here (http://strathprints.strath.ac.uk/50435/). Emerald does not grant permission for this article to be further copied/distributed or hosted elsewhere without the express permission from Emerald Group Publishing Limited.

\begin{tabular}{|c|c|c|c|c|c|c|c|c|c|c|}
\hline & \multicolumn{5}{|c|}{ Muldrew 2011} & \multicolumn{5}{|c|}{ Floud et al. 2011 (interpolated) } \\
\hline & $\begin{array}{l}\text { Total weight of } \\
\text { consumption } \\
\text { (lbs) }\end{array}$ & Population & $\begin{array}{l}\text { Pounds per } \\
\text { person per } \\
\text { day } \\
\text { (calculated) }\end{array}$ & $\begin{array}{l}\text { Calories } \\
\text { per } \\
\text { pound }\end{array}$ & $\begin{array}{c}\text { Calories per } \\
\text { day } \\
\text { (calculated) }\end{array}$ & $\begin{array}{l}\text { Total weight of } \\
\text { consumption } \\
\text { (lbs) }\end{array}$ & Population & $\begin{array}{c}\text { Pounds per } \\
\text { person per } \\
\text { day } \\
\text { (calculated) }\end{array}$ & $\begin{array}{l}\text { Calories } \\
\text { per } \\
\text { pound }\end{array}$ & $\begin{array}{c}\text { Calories per } \\
\text { day } \\
\text { (calculated) }\end{array}$ \\
\hline Beef and veal" & $403,000,000$ & $6,405,166$ & 0.1724 & $1,100.0$ & 187.7 & $316,960,000$ & $7,404,583$ & 0.1191 & 1,318 & 156.96 \\
\hline Sheep & $454,240,000$ & $6,405,166$ & 0.1943 & $1,100.0$ & 213.7 & $255,808,000$ & $7,404,583$ & 0.0949 & 1,472 & 139.77 \\
\hline Swine $^{\dagger}$ & $260,000,000$ & $6,405,166$ & 0.1112 & $1,214.0$ & 135.0 & $214,590,500$ & $7,404,583$ & 0.0805 & 2,348 & 188.95 \\
\hline Others $^{\ddagger}$ & $97,600,000$ & $6,405,166$ & 0.0417 & - & 41.9 & 0 & $7,404,583$ & - & 687 & 0.00 \\
\hline \multirow[t]{4}{*}{ Total $^{* *}$} & $1,617,840,000$ & $6,405,166$ & 0.5196 & - & 578.3 & $28,212,000$ & $3,715,255$ & - & 0 & 485.68 \\
\hline & \multicolumn{10}{|c|}{1800} \\
\hline & \multicolumn{5}{|c|}{ Muldrew 2011} & \multicolumn{5}{|c|}{ Floud et al. 2011} \\
\hline & $\begin{array}{c}\text { Total weight of } \\
\text { consumption } \\
\text { (lbs) }\end{array}$ & Population & $\begin{array}{c}\text { Pounds per } \\
\text { person per } \\
\text { day } \\
\text { (calculated) }\end{array}$ & $\begin{array}{c}\text { Calories } \\
\text { per } \\
\text { pound }\end{array}$ & $\begin{array}{c}\text { Calories per } \\
\text { day } \\
\text { (calculated) }\end{array}$ & $\begin{array}{c}\text { Total weight of } \\
\text { consumption } \\
\text { (lbs) }\end{array}$ & Population & $\begin{array}{c}\text { Pounds per } \\
\text { person per } \\
\text { day } \\
\text { (calculated) }\end{array}$ & $\begin{array}{l}\text { Calories } \\
\text { per } \\
\text { pound }\end{array}$ & $\begin{array}{c}\text { Calories per } \\
\text { day } \\
\text { (calculated) }\end{array}$ \\
\hline Beef and veal" & - & - & - & - & - & $364,000,000$ & $9,223,320$ & 0.1081 & 1,318 & 142.53 \\
\hline Sheep & - & - & - & - & - & $313,600,000$ & $9,223,320$ & 0.0932 & 1,472 & 137.14 \\
\hline Swine $^{\dagger}$ & - & - & - & - & - & $248,723,750$ & $9,223,320$ & 0.0739 & 2,348 & 173.46 \\
\hline Others $^{\ddagger}$ & - & - & - & - & - & - & $9,223,320$ & - & 687 & 0.00 \\
\hline Total $^{* *}$ & - & - & - & - & 428.0 & & - & & - & 453.13 \\
\hline
\end{tabular}

Notes.

'Beef and veal' includes cattle and calves)

'Swine' includes pork, ham and lard.

‡ 'Others' includes chickens, turkeys, geese, ducks and deer.

$*: \quad$ All Figures may differ slightly from published figures as a result of rounding.

Sources: Muldrew, 2011, pp. 142-3, 154-6; Floud et al., 2011, pp. 201-11. 
This article is (c) Emerald Group Publishing and permission has been granted for this version to appear here

(http://strathprints.strath.ac.uk/50435/). Emerald does not grant permission for this article to be further copied/distributed or hosted elsewhere without the express permission from Emerald Group Publishing Limited.

Table 34. Calories from dairy products: Muldrew versus Floud et al.

\begin{tabular}{|c|c|c|c|c|c|c|c|}
\hline & & & oud et al. & & & Muldrew & \\
\hline & Units & 1750 & 1800 & 1850 & 1700 & 1770 & 1800 \\
\hline $\begin{array}{l}\text { Cows producing milk } \\
\text { (millions) }\end{array}$ & & 0.015 & - & 0.150 & - & - & - \\
\hline $\begin{array}{l}\text { Cows producing butter and } \\
\text { flet cheese (millions) }\end{array}$ & & 0.500 & - & 0.700 & - & - & - \\
\hline $\begin{array}{l}\text { Cows producing cheese } \\
\text { (millions) }\end{array}$ & & 0.250 & - & 0.350 & - & - & - \\
\hline Total dairy cows (millions) & & 0.765 & - & 1.200 & 1.100 & 1.100 & 1.100 \\
\hline Yield per cow (milk) & gallons & 600 & - & 600 & 300 & 400 & 400 \\
\hline Yield per cow (butter) & Ibs & 140 & - & 200 & - & - & - \\
\hline Yield per cow (cheese) & lbs & 336 & - & 448 & - & - & - \\
\hline $\begin{array}{l}\text { Yield per cow (by-products, } \\
\text { all cows) }\end{array}$ & $\begin{array}{l}\text { gallons } \\
\text { (millions) }\end{array}$ & 67 & - & 76 & - & - & - \\
\hline Total yield (fresh milk) & $\begin{array}{l}\text { gallons } \\
\text { (millions) }\end{array}$ & 9 & - & 90 & - & - & - \\
\hline Total yield (milk by-products) & $\begin{array}{l}\text { gallons } \\
\text { (millions) }\end{array}$ & 51.37 & - & 90.62 & - & - & - \\
\hline $\begin{array}{l}\text { Total yield (milk and milk by- } \\
\text { products) }\end{array}$ & $\begin{array}{l}\text { gallons } \\
\text { (millions) }\end{array}$ & 60.37 & 54 & 180.62 & - & - & - \\
\hline Total yield (butter) & Ibs (millions) & 70 & 74 & 140 & - & - & - \\
\hline Total yield (cheese) & Ibs (millions) & 84 & - & 157 & - & - & - \\
\hline Total yield (flet cheese) & Ibs (millions) & 16 & - & 34 & - & - & - \\
\hline $\begin{array}{l}\text { Total yield (cheese and flet } \\
\text { cheese) }\end{array}$ & Ibs (millions) & 99.68 & 135 & 190.40 & - & - & - \\
\hline Population (millions) & & 6.192 & 9.223 & 17.926 & 4.897 & 6.405 & 8.606 \\
\hline $\begin{array}{l}\text { Yield per head per day (fresh } \\
\text { milk) }\end{array}$ & fluid ounces & 0.64 & - & 2.20 & - & - & - \\
\hline $\begin{array}{l}\text { Yield per head per day (milk } \\
\text { by-products) }\end{array}$ & ounces & 3.64 & - & 2.22 & - & - & - \\
\hline $\begin{array}{l}\text { Yield per head per day (milk } \\
\text { and milk by-products) }\end{array}$ & & - & 2.57 & - & - & - & - \\
\hline $\begin{array}{l}\text { Yield per head per day } \\
\text { (butter) }\end{array}$ & ounces & 0.50 & 0.50 & 0.34 & - & - & - \\
\hline $\begin{array}{l}\text { Yield per head per day } \\
\text { (cheese) }\end{array}$ & ounces & 0.59 & - & 0.38 & - & - & - \\
\hline $\begin{array}{l}\text { Yield per head per day (flet } \\
\text { cheese) }\end{array}$ & ounces & 0.11 & - & 0.08 & - & - & - \\
\hline $\begin{array}{l}\text { Yield per head day (cheese } \\
\text { and flet cheese) }\end{array}$ & ounces & - & 0.64 & - & - & - & - \\
\hline Calories per gallon of milk & & 3,256 & 3,256 & 3,256 & 3,200 & 3,200 & 3,200 \\
\hline Calories per pound of butter & & 3,612 & 3,612 & 3,612 & - & - & - \\
\hline $\begin{array}{l}\text { Calories per pound of cheese } \\
\text { (including flet cheese) }\end{array}$ & & 1,758 & 1,758 & 1,758 & - & - & - \\
\hline $\begin{array}{l}\text { Calories from milk and milk } \\
\text { by-products (million) }\end{array}$ & & 196,574 & 176,165 & 588,114 & - & - & - \\
\hline Calories from butter (million) & & 252,874 & 38,005 & 505,747 & - & - & - \\
\hline $\begin{array}{l}\text { Calories from cheese } \\
\text { (million) }\end{array}$ & & 175,198 & 237,736 & 334,647 & - & - & - \\
\hline Total calories (millions) & & 624,645 & 451,905 & $1,428,508$ & $1,056,000$ & $1,408,000$ & $1,408,000$ \\
\hline Calories per cow & & 816,530 & - & $1,190,423$ & 960,000 & $1,280,000$ & $1,280,000$ \\
\hline $\begin{array}{l}\% \text { dairy products fed to } \\
\text { animals }\end{array}$ & & - & - & - & 0.2 & 0.2 & 0.2 \\
\hline $\begin{array}{l}\text { Calories per person per day } \\
\text { (milk and milk by-products) }\end{array}$ & & 86.98 & 52.33 & 89.87 & - & - & - \\
\hline $\begin{array}{l}\text { Calories per person per day } \\
\text { (butter) }\end{array}$ & & 111.89 & 112.89 & 77.29 & - & - & - \\
\hline $\begin{array}{l}\text { Calories per person per day } \\
\text { (cheese and flet cheese) }\end{array}$ & & 77.52 & 70.62 & 51.14 & - & - & - \\
\hline Calories per person per day & & 276.38 & 235.84 & 218.30 & 472.67 & 481.80 & 358.59 \\
\hline
\end{tabular}

Notes. Figures may differ slightly from published figures as a result of rounding.

Sources: Muldrew, 2011, pp. 142-3, 154-6, 253; Holderness, 1989, p. 170; Floud et al., 2011 pp. 201-11. 
Although this strategy helps to modify some of Muldrew's original claims, it also raises new questions of its own. As we have already seen, there are some minor differences between the figures which Muldrew and Floud et al. used to convert bushels into pounds and to estimate the calorific value of different cereals, and a more serious difference between the figures they used to calculate the calorific value of beans and peas. They also used different values to calculate the number of calories obtained from meat and dairy products. Although these differences are not particularly dramatic, they do create inconsistencies when seeking to create a single series which uses Muldrew's values to estimate the number of calories derived from domestic food products between 1700 and 1800 , and Floud et al.'s values to calculate the calorific value of domestically-produced food between 1850 and 1909/13, and the calorific value of imported foods over the period as a whole.

Meredith and Oxley's paper also raises some important questions about the overall trajectory of domestic agriculture during the eighteenth and nineteenth centuries. As we have already seen, Muldrew did not attempt to extend his series beyond 1800 , and this meant that he was able to avoid a direct contrast between his estimates and those of nineteenth-century observers. However, by combining his figures on the amount of land under cultivation and the number of cattle in the eighteenth century with Floud et al.'s figures for the nineteenth century, Meredith and Oxley are forced into the position of not only accepting his eighteenth-century figures, but also accepting that the pace of change during the first half of the nineteenth century was much lower than other accounts might suggest. It then becomes necessary to explain, not only why increases in domestic agricultural 
This article is (c) Emerald Group Publishing and permission has been granted for this version to appear here

(http://strathprints.strath.ac.uk/50435/). Emerald does not grant permission for this article to be further copied/distributed or hosted elsewhere without the express permission from Emerald Group Publishing Limited.

production were so marked before 1800 , but also why the pace of change was so

much slower in the fifty years which followed.

Meredith and Oxley have also sought to reinforce their revised food estimates by comparing them with information on prices and stature. They argue that "when nutrition was improving over the eighteenth century, prices were low. When per capita output dropped, food prices escalated, exacerbated by war expenditure. When war ended, prices stabilised, but at a higher level than earlier, squeezing family incomes at a time when families had more mouths than ever before' (Meredith and Oxley, 2014, p. 184). However, while this may be true, it is also important to take account of changing wage levels. When wages and prices are combined, the case for nutritional pessimism becomes less convincing.

We can explore this question in more detail by comparing three sets of price and wage estimates. Figure 2 is derived from Gregory Clark's (2007, Table 4) calculations, showing changes in farm workers' wages and the cost of living between 1700 and 1849 . It shows that prices did indeed rise sharply from the 1780s onwards, but so did wages, and the increase in wages appears to have outstripped prices from the early-1800s. Figure 3 compares Phelps Brown and Hopkins' classic account of real wages in the country as a whole with the more recent series published by Charles Feinstein (1998) and Robert Allen (2007). In contrast to the earlier work, both Feinstein and Allen found evidence of a slow improvement in purchasing power between 1770 and 1800 , followed by a period of more rapid improvement beginning in either the 1820 s or 1830 s. 
This article is (c) Emerald Group Publishing and permission has been granted for this version to appear here

(http://strathprints.strath.ac.uk/50435/). Emerald does not grant permission for this article to be further copied/distributed or hosted elsewhere without the express permission from Emerald Group Publishing Limited.

\section{Figure 2. Farm workers' wages, 1700/09- $1860 / 69$}

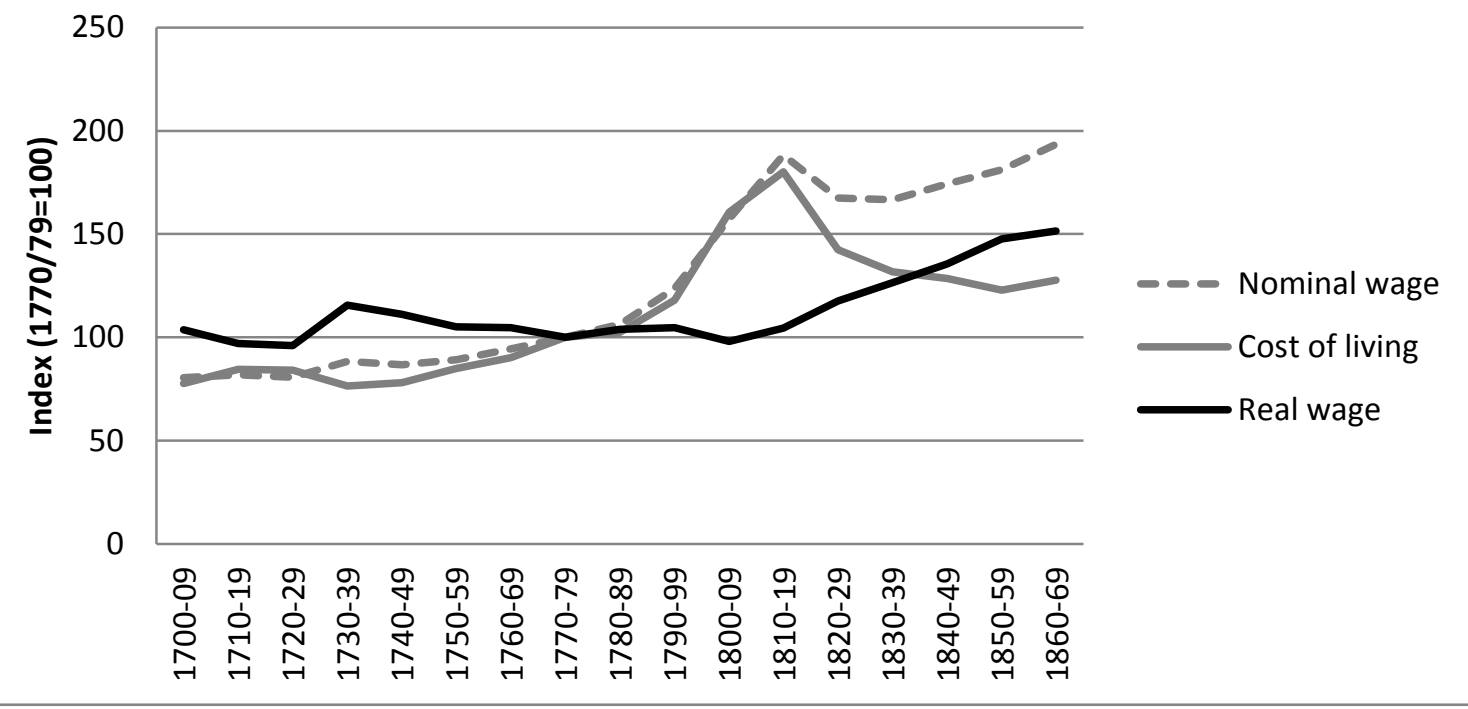

Source: Clark, 2007, pp. 130-4.

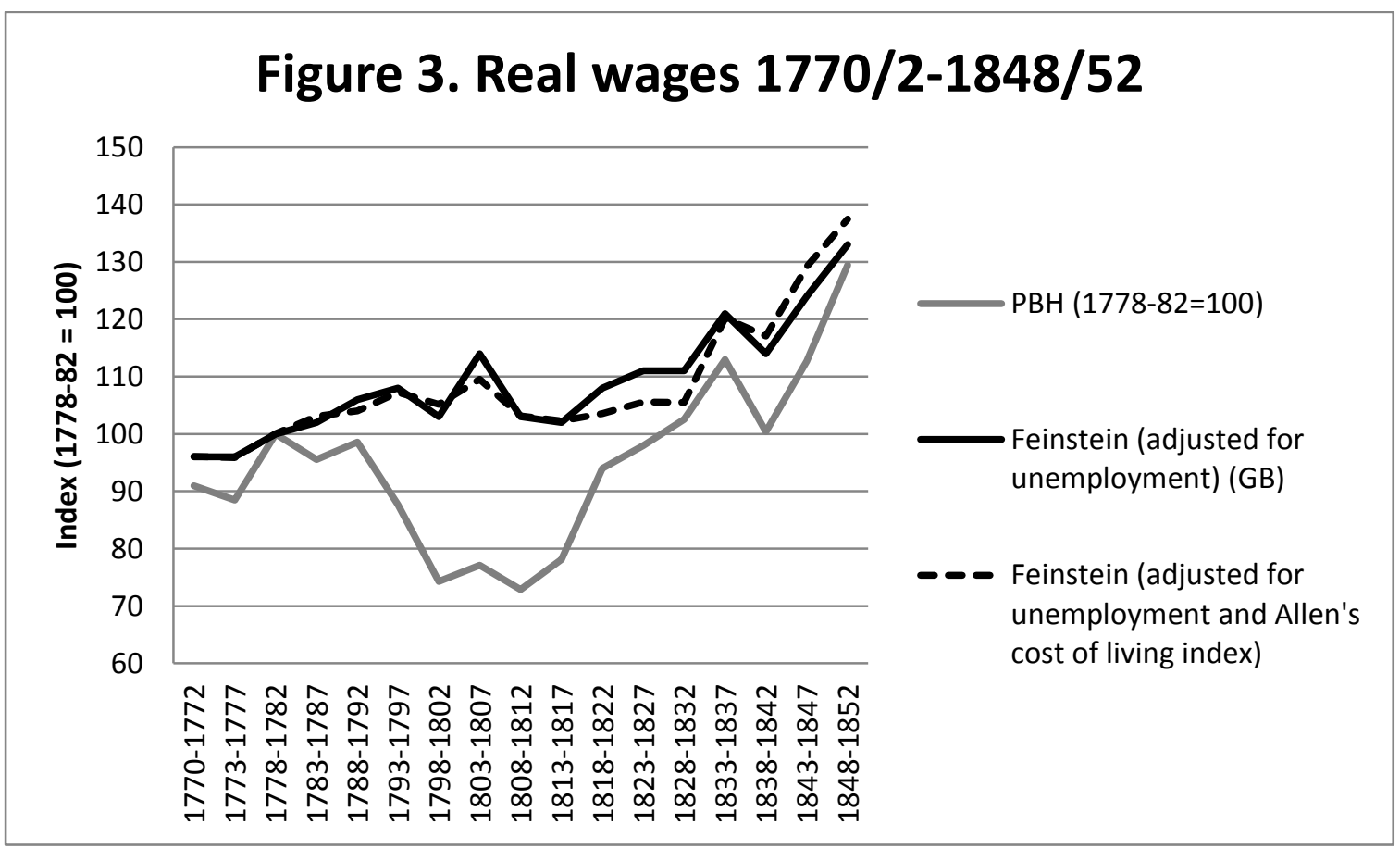

Sources: Wrigley and Schofield, 1981, pp. 642-4; Feinstein, 1998, p. 648; Allen, 2007, p. 36.

Meredith and Oxley have also compared changes in food availability with average male stature. As they rightly suggest, 'the dimensions of the human body its height, weight, body mass, waist-hip ratio - are clues to the nutritional 
This article is (c) Emerald Group Publishing and permission has been granted for this version to appear here

(http://strathprints.strath.ac.uk/50435/). Emerald does not grant permission for this article to be further copied/distributed or hosted elsewhere without the express permission from Emerald Group Publishing Limited.

experience of individuals' (Meredith and Oxley, 2014, p. 184), although it is

important to emphasise that height itself measures the net impact of diet on human growth after taking account of the demands imposed by physical activity and the disease environment. Their argument that changes in average stature reflect increases in nutritional hardship is based on four anthropometric series. Three of these were drawn from the measurements of convicts and prisoners, and the fourth from military data.

Meredith and Oxley obtained data on the heights of men who were imprisoned in Bedford and Wandsworth (London), and compared these with the heights of convicts who were transported from Britain to New South Wales and Van Diemen's Land. The oldest men in the Wandsworth dataset were only born during the second decade of the nineteenth century and therefore provide limited information about trends in height before that period, and neither the Bedford prisoners nor the Australian convicts provide unequivocal evidence of declines in stature before the 1820s (see Meredith and Oxley, 2014, pp. 188-91). However, Meredith and Oxley also revisited Floud et al.'s (1990) military data. Their reworking of these statistics provided much sharper evidence of a decline in stature from the birth cohorts of the 1770s onwards.

The estimation of the height of eighteenth-century military recruits has long been the subject of controversy. A number of authors, including John Komlos (Komlos, 1993a, 1993b; Komlos and Küchenhoff, 2012) and Francesco Cinnirella (2008), have argued that the data provide evidence of declines in stature of up to five inches $(12.7 \mathrm{~cm})$ between the birth cohorts of the $1740 \mathrm{~s}$ and the $1850 \mathrm{~s}$. By contrast, Floud et al. (1990, pp. 134-49) argued that there was a slow and irregular improvement in the average height of successive cohorts of British males born between the 1740 s and the 1820 s. 
This article is (c) Emerald Group Publishing and permission has been granted for this version to appear here

(http://strathprints.strath.ac.uk/50435/). Emerald does not grant permission for this article to be further copied/distributed or hosted elsewhere without the express permission from Emerald Group Publishing Limited.

One of the main areas of contention has been the question of whether, and at

what point, it might be appropriate to pool the results obtained from the analysis of the Army and the Marines. Komlos (1993a, p. 132) and Cinnirella (2008, p. 328) argued that the two services recruited men from different sections of the population and should therefore be treated separately. Floud et al. (1990, pp. 139-50; 1993, pp. 147-8) argued that recruits to both the Army and the Marines were drawn from the same section of the population (the male working class) and that the allocation of recruits to different services was simply a matter of military convenience.

Meredith and Oxley agreed with Floud, Wachter and Gregory on this point. However, they also noted that the Army and the Marines had different height profiles, and they argued that Floud and his coauthors misrepresented the overall trend by overweighting the proportion of Marines in the overall sample. They then recalculated Floud, Wachter and Gregory's results after reweighting the data to take account of the actual proportions of Army and Marine recruits and excluding recruits from outside England and Wales, and this formed the basis of their revised estimates (Meredith and Oxley, 2014, p. 188; see also Floud et al., 1993, pp. 147-8).

Meredith and Oxley's estimates represent an important contribution to anthropometric history, but their decision to reweight the data according to the proportions of Army and Marine recruits is surely open to question. They argued that pooling the data without reweighting would be analogous to 'mix[ing] up disproportionate shares of males and females and consider[ing] the outcome representative' (Meredith and Oxley, 2014, pp. 187-8). However, the reason why it would be inappropriate to mix up disproportionate (and varying) shares of males and females is because the distributions of heights in the underlying populations are different. If one accepts the view that both the Army recruits and the Marine recruits were drawn from the same population, then it is appropriate to combine 
This article is (c) Emerald Group Publishing and permission has been granted for this version to appear here

(http://strathprints.strath.ac.uk/50435/). Emerald does not grant permission for this article to be further copied/distributed or hosted elsewhere without the express permission from Emerald Group Publishing Limited.

them, providing one makes appropriate allowances for variations in the height

standards used to select them (see Floud, Wachter and Gregory, 1990, pp. 111-4;

1993, pp. 147-8).

Meredith and Oxley sought to allow for the effects of truncation by controlling for the size of the Army and Marine establishments in the year of recruitment. Even though this did not allow them to infer the actual heights of the underlying population, they argued that it was sufficient to enable them to estimate overall trends (Meredith and Oxley, 2014, p. 188). However, other contributors to these debates have been much less reticent. Indeed, many of the main disagreements between Komlos and Cinnirella, and Floud and his coauthors, have concerned the identification and development of the most appropriate procedures for making inferences about the heights of underlying populations from truncated samples, and this remains a hotly-contested issue (see e.g. Komlos, 2004; Floud et al., 2011 , pp. $65-7,137)$.

In the absence of any unequivocal resolution of these debates, it may be more appropriate, at this juncture, to compare the latest height series with changes in mortality. Although there has been some debate over the course of mortality change during the first half of the eighteenth century (Razzell, 1994, pp. 185-95; 1998, pp. 485-500), most observers seem content to accept Wrigley and Schofield's broad depiction of changes in life expectancy during the second half of the eighteenth century and the first half of the nineteenth century (see e.g. Hinde 2003, pp. 184, 194). However, as we can see from Figure 4 , these data provide relatively little evidence of any clear decline in life expectancy before the second quarter of the nineteenth century. If nutritional standards were falling as sharply as Meredith and Oxley suggest, there is little evidence that this had any effect on mortality. 
This article is (c) Emerald Group Publishing and permission has been granted for this version to appear here

(http://strathprints.strath.ac.uk/50435/). Emerald does not grant permission for this article to be further copied/distributed or hosted elsewhere without the express permission from Emerald Group Publishing Limited.

\section{Figure 4. Expectation of life at birth in England (and Wales), 1701-1910}

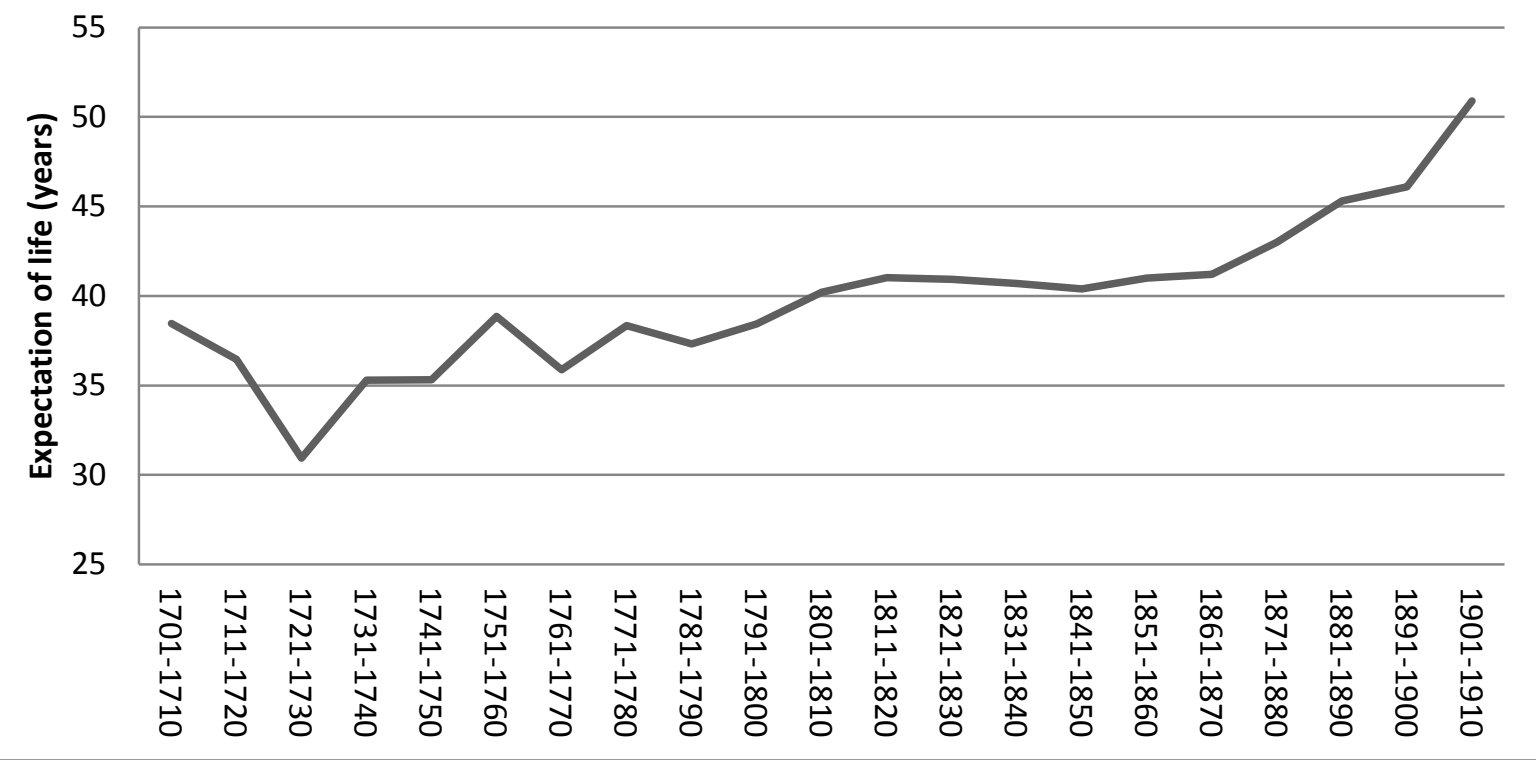

Source: Floud et al., 2011 , p. 146.

\section{Conclusions}

There is a sizable gap between the conclusions which different authors have reached regarding the amount of food which was available for human consumption in England, or England and Wales, between circa 1700 and 1850. Both Broadberry et al. (2011; forthcoming) and Floud et al. (2011) argued that nutritional levels were generally rather low throughout the eighteenth and early-nineteenth centuries, although Floud et al.'s figures were more generous, and they saw more evidence of improvement over the period as a whole. Both Allen (2005) and Muldrew (2011) reached much more optimistic conclusions about the amount of food available before the mid- to late-eighteenth century, although Allen believed that food supplies declined sharply after that point. Meredith and Oxley's (2014) conclusions imply that the amount of food was somewhat lower than either Allen or Muldrew suggested, but they still see evidence of a substantial decline between the lateeighteenth and mid-nineteenth centuries. 
This article is (c) Emerald Group Publishing and permission has been granted for this version to appear here

(http://strathprints.strath.ac.uk/50435/). Emerald does not grant permission for this article to be further copied/distributed or hosted elsewhere without the express permission from Emerald Group Publishing Limited.

These disparities reflect differences in both assumptions and methods. As

Meredith and Oxley (2014, p. 173) have pointed out, Muldrew and Floud et al. used similar methods but reached very divergent conclusions. Broadberry et al. approached the subject in a rather different way to Floud and his coauthors and there are disagreements, but their results are broadly similar (at least in terms of levels, if not trajectory). The main reasons for the disparity between Muldrew's series and those of other authors lie in the assumptions he makes about the amount of land under cultivation, especially towards the end of the eighteenth century; the number of animals producing food for human consumption; and the amount of food lost during the production process. Many of these assumptions seem highly optimistic when compared with the conclusions reached by other authors, and this suggests that the truth is likely to lie somewhat closer to Floud et al. and Broadberry et al., even if further revision of their estimates may still be necessary.

Although there is a broad similarity between Floud et al.'s results and those of Broadberry et al., there are also differences. As we have seen, Floud et al. have already presented two different sets of estimates, reflecting different assumptions about arable productivity. The corrected and updated version of Estimate A suggests that food availability increased over the course of the eighteenth century, followed by a period of stagnation between 1800 and 1850. In contrast, the corrected and updated version of Estimate B suggests that food availability declined between 1750 and 1800 and only improved after this date. Broadberry et al.'s figures are more consistent with the latter view but this conclusion can also be questioned. If we were to apply Floud et al.'s assessment of the number of calories supplied by imported foods to Broadberry et al.'s domestic figures, the overall 
This article is (c) Emerald Group Publishing and permission has been granted for this version to appear here

(http://strathprints.strath.ac.uk/50435/). Emerald does not grant permission for this article to be further copied/distributed or hosted elsewhere without the express permission from Emerald Group Publishing Limited.

pattern would be much closer to the corrected version of Estimate A (see Appendix

1). ${ }^{8}$

In the meantime, it is also important to consider what these figures might say about the overall level of nutritional adequacy. As Floud et al. (2011, pp. 41, 77-8, 129-30, 162) pointed out, the nutritional adequacy of a diet depends not only on its size but also its composition (and the environment in which it is consumed). Eric Schneider (2013) has taken this argument further by applying modern theories about the 'digestibility' of different foods to Floud et al.'s corrected data. Although his findings do little to alter the overall trajectory of nutritional change, they provide further grounds for thinking that the nutritional lot of many eighteenth and nineteenth century consumers left much to be desired.

This point would of course be even more true if we were to include Irish imports.

Forthcoming in Research in Economic History, 31 (2015) 
This article is $\odot$ Emerald Group Publishing and permission has been granted for this version to appear here (http://strathprints.strath.ac.uk/50435/). Emerald does not grant permission for this article to be further copied/distributed or hosted elsewhere without the express permission from Emerald Group Publishing Limited.

Appendix 1.

\begin{tabular}{|c|c|c|c|c|c|c|c|c|c|c|c|c|c|}
\hline Year/s & Author/s & & Domestic & alories & & & mported cal & ories & & & Tot & & \\
\hline & & $\begin{array}{l}\text { Cereals, } \\
\text { pulses and } \\
\text { vegetables }\end{array}$ & $\begin{array}{c}\text { Meat } \\
\text { and } \\
\text { dairy } \\
\text { products }\end{array}$ & $\begin{array}{l}\text { Other } \\
\text { foods }\end{array}$ & Total & $\begin{array}{l}\text { Cereals, } \\
\text { pulses and } \\
\text { vegetables }\end{array}$ & $\begin{array}{l}\text { Meat and } \\
\text { dairy } \\
\text { products }\end{array}$ & $\begin{array}{l}\text { Other } \\
\text { foods }\end{array}$ & Total & $\begin{array}{l}\text { Cereals, } \\
\text { pulses and } \\
\text { vegetables }\end{array}$ & $\begin{array}{l}\text { Meat and } \\
\text { dairy } \\
\text { products }\end{array}$ & $\begin{array}{l}\text { Other } \\
\text { foods }\end{array}$ & Total \\
\hline $1270 / 79$ & Broadberry et al., forthcoming & 1,786 & 117 & 300 & 2,203 & 0 & 0 & 0 & 0 & 1,786 & 117 & 300 & 2,203 \\
\hline 1300 & Allen, 2005 & 1,502 & 289 & 0 & 1,791 & 0 & 0 & 0 & 0 & 1,502 & 289 & 0 & 1,791 \\
\hline 1300 & Overton and Campbell, 1996 & $1,446-1,626$ & $n / a$ & $n / a$ & $n / a$ & 0 & $n / a$ & $n / a$ & $n / a$ & $1,446-1,626$ & $n / a$ & $n / a$ & $n / a$ \\
\hline $1300 / 09$ & Broadberry et al., forthcoming & 1,625 & 131 & 300 & 2,056 & 0 & 0 & 0 & 0 & 1,625 & 131 & 300 & 2,056 \\
\hline $1310 / 19$ & Broadberry et al., forthcoming & 1,576 & 122 & 300 & 1,998 & 0 & 0 & 0 & 0 & 1,576 & 122 & 300 & 1,998 \\
\hline 1380 & Overton and Campbell, 1996 & $1,669-1,500$ & $\mathrm{n} / \mathrm{a}$ & $\mathrm{n} / \mathrm{a}$ & $\mathrm{n} / \mathrm{a}$ & 0 & $\mathrm{n} / \mathrm{a}$ & $n / a$ & $\mathrm{n} / \mathrm{a}$ & $1,669-1,500$ & $\mathrm{n} / \mathrm{a}$ & $\mathrm{n} / \mathrm{a}$ & $\mathrm{n} / \mathrm{a}$ \\
\hline $1380 / 89$ & Broadberry et al., forthcoming & 2,076 & 191 & 200 & 2,467 & 0 & 0 & 0 & 0 & 2,076 & 191 & 200 & 2,467 \\
\hline $1420 / 29$ & Broadberry et al., forthcoming & 1,716 & 230 & 200 & 2,146 & 0 & 0 & 0 & 0 & 1,716 & 230 & 200 & 2,146 \\
\hline $1450 / 59$ & Broadberry et al., forthcoming & 1,712 & 264 & 200 & 2,176 & 0 & 0 & 0 & 0 & 1,712 & 264 & 200 & 2,176 \\
\hline 1500 & Allen, 2005 & 2,733 & 664 & 0 & 3,397 & 0 & 0 & 0 & 0 & 2,733 & 664 & 0 & 3,397 \\
\hline 1600 & Muldrew, 2011 & 1,968 & 1,094 & 0 & 3,062 & 0 & 0 & 0 & 0 & 1,968 & 1,094 & 0 & 3,062 \\
\hline 1600 & Overton and Campbell, 1996 & 1,230 & $n / a$ & $n / a$ & $n / a$ & 0 & $n / a$ & $n / a$ & $n / a$ & 1,230 & $n / a$ & $n / a$ & $n / a$ \\
\hline $1600 / 09$ & Broadberry et al., forthcoming & 1,698 & 206 & 200 & 2,104 & 0 & 0 & 0 & 0 & 1,698 & 206 & 200 & 2,104 \\
\hline $1650 / 59$ & Broadberry et al., forthcoming & 1,576 & 169 & 200 & 1,945 & 0 & 0 & 0 & 0 & 1,576 & 169 & 200 & 1,945 \\
\hline 1700 & Allen, 2005 & 2,624 & 616 & 0 & 3,240 & -23 & 38 & 0 & 15 & 2,601 & 654 & 0 & 3,255 \\
\hline 1700 & Floud et al., 2011 (Estimates A and B) & 1,631 & 538 & 34 & 2,203 & -13 & 0 & 40 & 27 & 1,618 & 538 & 74 & 2,230 \\
\hline 1700 & Fogel, 2004 & $\mathrm{n} / \mathrm{a}$ & $\mathrm{n} / \mathrm{a}$ & $\mathrm{n} / \mathrm{a}$ & $n / a$ & $n / a$ & $n / a$ & $n / a$ & $n / a$ & $n / a$ & $n / a$ & $n / a$ & 2,095 \\
\hline 1700 & Meredith and Oxley, 2014 & 1,633 & 897 & 0 & 2,530 & -13 & 0 & 40 & 27 & 1,620 & 897 & 40 & 2,557 \\
\hline 1700 & Muldrew, 2011 & 2,682 & 897 & 0 & 3,579 & 0 & 0 & 0 & 0 & 2,682 & 897 & 0 & 3,579 \\
\hline 1700 & Overton and Campbell, 1996 & 3,014 & $n / a$ & $\mathrm{n} / \mathrm{a}$ & $n / a$ & -60 & $n / a$ & $n / a$ & $n / a$ & 2,954 & $n / a$ & $n / a$ & $n / a$ \\
\hline $1700 / 09$ & Broadberry et al., forthcoming & 1,777 & 210 & 200 & 2,187 & 0 & 0 & 0 & 0 & 1,777 & 210 & 200 & 2,187 \\
\hline 1750 & Allen, 2005 & 3,157 & 752 & 0 & 3,909 & -195 & 89 & 0 & -106 & 2,962 & 841 & 0 & 3,803 \\
\hline 1750 & Floud et al., 2011 (Estimate A; with correction) & 1,593 & 786 & 34 & 2,413 & -168 & 0 & 83 & -85 & 1,425 & 786 & 117 & 2,328 \\
\hline 1750 & Floud et al., 2011 (Estimate B; with correction) & 1,781 & 786 & 34 & 2,601 & -168 & 0 & 83 & -85 & 1,613 & 786 & 117 & 2,516 \\
\hline 1750 & Fogel, 2004 & $\mathrm{n} / \mathrm{a}$ & $\mathrm{n} / \mathrm{a}$ & $\mathrm{n} / \mathrm{a}$ & $n / a$ & $n / a$ & $n / a$ & $\mathrm{n} / \mathrm{a}$ & $n / a$ & $n / a$ & $n / a$ & $n / a$ & 2,168 \\
\hline 1750 & Kelly and Ó Gráda, 2013b & $2,024-2,054$ & 733 & 47 & $2,804-2,844$ & 0 & $20-25$ & 90 & $110-115$ & $2,024-2,054$ & $753-758$ & 137 & 2,914-2,949 \\
\hline $1750 / 59$ & Broadberry et al., forthcoming & 1,734 & 319 & 200 & 2,253 & 20 & 0 & 0 & 20 & 1,754 & 319 & 200 & 2,273 \\
\hline 1770 & Kelly and Ó Gráda, 2013b & 2,370 & 1,062 & 0 & 3,432 & 0 & $20-25$ & 90 & $110-115$ & 2,370 & $1,082-1,087$ & 90 & $3,542-3,547$ \\
\hline 1770 & Meredith and Oxley, 2014 & 2,209 & 1,062 & 0 & 3,271 & 0 & 0 & 0 & 0 & 2,209 & 1,062 & 0 & 3,271 \\
\hline 1770 & Muldrew, 2011 & 3,985 & 1,062 & 0 & 5,047 & 0 & 0 & 0 & 0 & 3,985 & 1,062 & 0 & 5,047 \\
\hline 1800 & Allen, 2005 & 2,018 & 532 & 0 & 2,550 & 230 & 158 & 0 & 388 & 2,248 & 690 & 0 & 2,938 \\
\hline 1800 & Floud et al., (Estimate A) & 1,532 & 692 & 34 & 2,258 & 86 & 16 & 112 & 214 & 1,618 & 708 & 146 & 2,472 \\
\hline 1800 & Floud et al., (Estimate B) & 1,499 & 692 & 34 & 2,225 & 86 & 16 & 112 & 214 & 1,585 & 708 & 146 & 2,439 \\
\hline
\end{tabular}


This article is $\odot$ Emerald Group Publishing and permission has been granted for this version to appear here (http://strathprints.strath.ac.uk/50435/). Emerald does not grant permission for this article to be further copied/distributed or hosted elsewhere without the express permission from Emerald Group Publishing Limited.

\begin{tabular}{|c|c|c|c|c|c|c|c|c|c|c|c|c|c|}
\hline 1800 & Fogel, 2004 & $n / a$ & $n / a$ & $n / a$ & $n / a$ & $n / a$ & $n / a$ & $n / a$ & $\mathrm{n} / \mathrm{a}$ & $n / a$ & $n / a$ & $\mathrm{n} / \mathrm{a}$ & 2,237 \\
\hline 1800 & Kelly and Ó Gráda, 2013b (Estimate A) & 2,019 & 692 & 60 & 2,771 & 0 & $60-75$ & 110 & $170-185$ & 2,019 & $752-767$ & 170 & $2,941-2,956$ \\
\hline 1800 & Kelly and Ó Gráda, 2013b (Estimate B) & 1,576 & 735 & 100 & $2,365-2,395$ & 168 & $60-75$ & 110 & $338-353$ & $1,744-1,774$ & 749-764 & 210 & $2,749-2,794$ \\
\hline 1800 & Meredith and Oxley, 2014 & 1,618 & 788 & 0 & 2,406 & 86 & 16 & 112 & 214 & 1,704 & 804 & 112 & 2,620 \\
\hline 1800 & Muldrew, 2011 & 3,189 & 788 & 0 & 3,977 & 0 & 0 & 0 & 0 & 3,189 & 788 & 0 & 3,977 \\
\hline 1800 & Overton and Campbell, 1996 & 1,518 & $n / a$ & $n / a$ & $n / a$ & 90 & $n / a$ & $n / a$ & $n / a$ & 1,608 & $n / a$ & $n / a$ & $n / a$ \\
\hline $1800 / 09$ & Broadberry et al., forthcoming & 1,436 & 385 & 200 & 2,021 & 168 & 0 & 0 & 168 & 1,604 & 385 & 200 & 2,189 \\
\hline 1830 & Overton and Campbell, 1996 & 1,298 & $n / a$ & $n / a$ & $n / a$ & 1,977 & $n / a$ & $n / a$ & $n / a$ & 3,275 & $n / a$ & $n / a$ & $\mathrm{n} / \mathrm{a}$ \\
\hline $1830 / 39$ & Broadberry et al., forthcoming & 1,300 & 311 & 200 & 1,811 & 160 & 0 & 0 & 160 & 1,460 & 311 & 200 & 1,971 \\
\hline $1840 / 49$ & Broadberry et al., forthcoming & 1,359 & 308 & 200 & 1,867 & 309 & 6 & 0 & 315 & 1,668 & 314 & 200 & 2,182 \\
\hline 1850 & Allen, 2005 & 1,559 & 411 & 0 & 1,970 & 460 & 95 & 0 & 555 & 2,019 & 506 & 0 & 2,525 \\
\hline 1850 & Floud et al., 2011 (Estimate A) & 1,349 & 567 & 34 & 1,950 & 366 & 32 & 157 & 555 & 1,715 & 599 & 191 & 2,505 \\
\hline 1850 & Floud et al., 2011 (Estimate B)/Meredith and Oxley 2013 & 1,389 & 567 & 34 & 1,990 & 366 & 32 & 157 & 555 & 1,755 & 599 & 191 & 2,545 \\
\hline 1850 & Fogel, 2004 & $n / a$ & $\mathrm{n} / \mathrm{a}$ & $\mathrm{n} / \mathrm{a}$ & $n / a$ & $n / a$ & $n / a$ & $\mathrm{n} / \mathrm{a}$ & $n / a$ & $\mathrm{n} / \mathrm{a}$ & $n / a$ & $\mathrm{n} / \mathrm{a}$ & 2,362 \\
\hline $1850 / 59$ & Broadberry et al., forthcoming & 1,073 & 328 & 200 & 1,601 & 524 & 10 & 0 & 534 & 1,597 & 338 & 200 & 2,135 \\
\hline $1861 / 70$ & Broadberry et al., forthcoming & 1,035 & 320 & 200 & 1,555 & 930 & 22 & 0 & 952 & 1,965 & 342 & 200 & 2,507 \\
\hline 1871 & Overton and Campbell, 1996 & 1,060 & $\mathrm{n} / \mathrm{a}$ & $\mathrm{n} / \mathrm{a}$ & $n / a$ & 736 & $n / a$ & $\mathrm{n} / \mathrm{a}$ & $n / a$ & 1,796 & $n / a$ & $\mathrm{n} / \mathrm{a}$ & $\mathrm{n} / \mathrm{a}$ \\
\hline $1909-13$ & Floud et al., 201 1/Meredith and Oxley, 2014 & 425 & 611 & 209 & 1,245 & 832 & 428 & 472 & 1,732 & 1,256 & 1,039 & 681 & 2,977 \\
\hline $1909-13$ & Fogel, 2004 & $\mathrm{n} / \mathrm{a}$ & $\mathrm{n} / \mathrm{a}$ & $\mathrm{n} / \mathrm{a}$ & $\mathrm{n} / \mathrm{a}$ & $n / a$ & $n / a$ & $\mathrm{n} / \mathrm{a}$ & $n / a$ & $n / a$ & $\mathrm{n} / \mathrm{a}$ & $\mathrm{n} / \mathrm{a}$ & 2,857 \\
\hline $1954 / 55$ & Fogel, 2004 & $n / a$ & $n / a$ & $n / a$ & $n / a$ & $n / a$ & $n / a$ & $\mathrm{n} / \mathrm{a}$ & $n / a$ & $\mathrm{n} / \mathrm{a}$ & $n / a$ & $n / a$ & 3,231 \\
\hline 1961 & Fogel, 2004 & $\mathrm{n} / \mathrm{a}$ & $\mathrm{n} / \mathrm{a}$ & $\mathrm{n} / \mathrm{a}$ & $\mathrm{n} / \mathrm{a}$ & $\mathrm{n} / \mathrm{a}$ & $\mathrm{n} / \mathrm{a}$ & $\mathrm{n} / \mathrm{a}$ & $\mathrm{n} / \mathrm{a}$ & $\mathrm{n} / \mathrm{a}$ & $\mathrm{n} / \mathrm{a}$ & $\mathrm{n} / \mathrm{a}$ & 3,170 \\
\hline 1965 & Fogel, 2004 & $n / a$ & $n / a$ & $\mathrm{n} / \mathrm{a}$ & $\mathrm{n} / \mathrm{a}$ & $n / a$ & $n / a$ & $n / a$ & $n / a$ & $\mathrm{n} / \mathrm{a}$ & $n / a$ & $n / a$ & 3,304 \\
\hline 1989 & Fogel, 2004 & $\mathrm{n} / \mathrm{a}$ & $\mathrm{n} / \mathrm{a}$ & $n / a$ & $\mathrm{n} / \mathrm{a}$ & $\mathrm{n} / \mathrm{a}$ & $n / a$ & $n / a$ & $\mathrm{n} / \mathrm{a}$ & $n / a$ & $n / a$ & $\mathrm{n} / \mathrm{a}$ & 3,149 \\
\hline
\end{tabular}

Notes: The figures attributed to Kelly and Ó Gráda are derived from the adjustments they proposed to the estimates published by Muldrew (2011) and Broadberry et al. (2011). In relation to their estimates for 1800, Estimate A is reflects their amendments to Muldrew's figures and Estimate B reflects their amendments to Broadberry et al.'s figures.

Sources: Allen, 2005, p. 39 (Table 12); Broadberry et al., forthcoming: Table 8.7; Floud et al., 2011, pp. $156-60$ (with corrections); Fogel, 2004, p. 9; Kelly and Ó Gráda, 2013 b, p. 3 (Appendix Table 3); Meredith and Oxley, 2014, pp. 16970; Muldrew, 201 1, pp. 140-56; Overton and Campbell, 1996, p. 296 (Table 13); Overton and Campbell, 2006, p. 45 (Table XIII). 
This article is (c) Emerald Group Publishing and permission has been granted for this version to appear here

(http://strathprints.strath.ac.uk/50435/). Emerald does not grant permission for this article to be further copied/distributed or hosted elsewhere without the express permission from Emerald Group Publishing Limited.

\section{Bibliography}

Allen, R. (1994). Agriculture during the industrial revolution. In R. Floud and D. McCloskey (Eds.), The economic history of Britain since 1700. Vol. 1. 1700-1860 (pp. 96-122). Cambridge: Cambridge University Press.

Allen, R. (2005). English and Welsh agriculture, 1300-1850: outputs, inputs and income'. Retrieved from http://economics.ouls.ox.ac.uk/13622/1/Allen\%20\%20English\%20and\%20Welsh\%20agriculture.pdf

Allen, R. (2007). Pessimism preserved: real wages in the British industrial revolution. Oxford University Department of Economics Working Paper 314.

Bennett, M.K. and Pierce, R.H. (1961). Change in the American national diet, 18791959. Food Research Institute Studies, 2(2), 95-119.

Bourke, A. (1993). The visitation of God'? The potato and the great Irish famine, Dublin: Lilliput Press.

Blackman, J. (1975). The cattle trade and agrarian change on the eve of the Railway Age. Agricultural History Review, 23(1), 48-62.

Broadberry, S., Campbell, B., Klein, A., Overton, M. and Van Leeuwen, B. (2011). British economic growth, 1270-1870'. Retrieved from http://www.Ise.ac.uk/economicHistory/seminars/ModernAndComparative/papers20 11-12/Papers/Broadberry.pdf.

Broadberry, S., Campbell, B., Klein, A., Overton, M. and Van Leeuwen, B. (forthcoming), British economic growth, 1270-1870, Cambridge: Cambridge University Press.

Burnett, J. (1979), Plenty and want: a social history of diet in England from 1815 to the present day, London: Methuen.

Burnette, J. (2014). Agriculture, 1700-1870. In R. Floud, J. Humphries and P. Johnson (Eds.), The Cambridge economic history of modern Britain. Vol. 1. 17001870 (pp. 89-117). Cambridge: Cambridge University Press.

Caird, J. (1852), English agriculture in 1850-51, London: Longman.

Capper, B.P. (1801), A statistical account of the population and cultivation, produce and consumption of England and Wales, London: T. Geoghegan.

Chartres, J.A. (1985). The marketing of agricultural produce. In J. Thirsk (Ed.), The agrarian history of England and Wales. Vol. V: 1640-1750; II: Agrarian change (pp. 406-502). Cambridge: Cambridge University Press.

Cinnirella, F. (2008). Optimists or pessimists? A reconsideration of nutritional status in Britain, 1740-1 865. European Review of Economic History, 12(3), 325-54. doi: $10.1017 / \mathrm{S} 136149160800227 \mathrm{X}$

Clark, G. (1991). Labour productivity in English agriculture, 1300-1860. In B. Campbell and M. Overton (Eds.), Agricultural productivity in the European past (pp. 21 1-35). Manchester: Manchester University Press. 
This article is (c) Emerald Group Publishing and permission has been granted for this version to appear here

(http://strathprints.strath.ac.uk/50435/). Emerald does not grant permission for this article to be further copied/distributed or hosted elsewhere without the express permission from Emerald Group Publishing Limited.

Clark, G. (2007). The long march of history: farm labourers' wages in England, 1209-1 869. Economic History Review, 60(1), 97-136. doi: $10.1111 / \mathrm{j} .1468$ -

0289.2006.00358.x

Collins, E.J.T. (1975). Dietary change and cereal consumption in Britain in the nineteenth century. Agricultural History Review, 23(2), 97-115.

Comber, W.T. (1808), An inquiry into the state of national subsistence, London: T. Cadell and W. Davies.

Cullen, L.M. (1968), Anglo-Irish trade, 1660-1800, Manchester: Manchester University Press.

Davies, D. (1795), The case of the labourers in husbandry stated and considered, Dublin: P. Byrne.

Donnelly, J. (1975), The land and the people of nineteenth-century Cork: the rural economy and the land question, London: Routledge and Kegan Paul.

Eden, F.M. (1797), The state of the poor, London: B \& J. White et al..

Feinstein, C.H. (1998). Pessimism perpetuated: real wages and the standard of living in Britain during and after the industrial revolution. Journal of Economic History, 58(3), 625-58.

Floud, R., Fogel, R., Harris, B. and Hong, S.C. (2011), The changing body: health, nutrition and human development in the western world since 1700, Cambridge: Cambridge University Press.

Floud, R., Fogel, R., Harris, B. and Hong, S.C. (forthcoming), The changing body: health, nutrition and human development in the western world since 1700, Cambridge: Cambridge University Press, new impression.

Floud, R., Wachter, K. and Gregory, A. (1990), Height, health and history: nutritional status in the United Kingdom 1750-1980, Cambridge: Cambridge University Press.

Floud, R., Wachter, K. and Gregory, A. (1993). Measuring historical heights: short cuts or the long way round? A reply to Komlos. Economic History Review, 46(1), 145-54.

Fogel, R. (2004), The escape from hunger and premature death, 1700-2100: Europe, America and the Third World, Cambridge: Cambridge University Press.

Galpin, W.F. (1925), The grain supply of England during the Napoleonic period, New York: Macmillan.

Gash, N. (1985), Mr Secretary Peel: the life of Sir Robert Peel to 1830, London: Longman.

Gazeley, I. and Newell, A. (2014). Urban working-class food consumption and nutrition in Britain in 1904. Economic History Review. Retrieved from http://onlinelibrary.wiley.com/doi/10.1111/ehr.12065/pdf.

Grant, A. (1766), The practical farmer's pocket companion, Aberdeen: F. Douglas. 
This article is (c) Emerald Group Publishing and permission has been granted for this version to appear here

(http://strathprints.strath.ac.uk/50435/). Emerald does not grant permission for this article to be further copied/distributed or hosted elsewhere without the express permission from Emerald Group Publishing Limited.

Harris, B. (2004). Public health, nutrition and the decline of mortality: the McKeown thesis revisited. Social History of Medicine, 17(3), 379-407. doi:

$10.1093 / \mathrm{shm} / 17.3 .379$

Hinde, A. (2003), England's population: a history since the Domesday survey, London: Edward Arnold.

Holderness, B.A. (1989). Prices, productivity and output. In G.E. Mingay (Ed.), The agrarian history of England and Wales. Vol. VI: 1750-1850 (pp. 84-189), Cambridge: Cambridge University Press, 1989.

John, A.H. (1989). Statistical appendix. In G.E. Mingay (Ed.), The agrarian history of England and Wales. Vol. VI. 1750-1850 (pp. 973-1131), Cambridge: Cambridge University Press.

Kain, R.J.P. (1986), An atlas and index of the tithe files of mid-nineteenth century England and Wales, Cambridge: Cambridge University Press.

Kain, R.J.P. and Prince, H.C. (1985), The tithe surveys of England and Wales, Cambridge: Cambridge University Press.

Kelly, M. and Ó Gráda, C. (2013a). Numerare est errare: agricultural output and food supply in England before and during the industrial revolution. Journal of Economic History, 73(4), $1132-1163$. doi: 10.1017/S0022050713000909

Kelly, M. and Ó Gráda, C. (2013b). Numerare est errare: agricultural output and food supply in England before and during the industrial revolution. Appendix: the components of agricultural output. Journal of Economic History, 73(4). Retrieved from

http://journals.cambridge.org/downloadsup.php?file=/S0022050713000909sup00 2.pdf\&code $=9 \mathrm{ffe} 31$ e82e20d62a5367dab8427fc72d\&mime=application/pdf.

King, G. (1696), Natural and political observations and conclusions upon the state and condition of England, 1696. Reprinted in P. Laslett (Ed.), The earliest classics, Farnsborough: Gregg, 1973.

Komlos, J. (1993a). The secular trend in the biological standard of living in the United Kingdom, 1730-1860. Economic History Review, 46(1), 11 5-44.

Komlos, J. (1993b). Further thoughts on the nutritional status of the British population. Economic History Review, 46(2), 363-6.

Komlos, J. (2004). How to (and how not to) analyze deficient height samples: an introduction. Historical Methods, 37(4), 160-73. doi:10.3200/HMTS.37.4.160-173

Komlos, J. and Küchenhoff, H. (2012). The diminution of the physical stature of the English male population in the eighteenth century. Cliometrica, 6(1), 45-62. doi: $10.1007 / \mathrm{s} 11698-011-0070-7$

Macgregor, J. (1850), Commercial statistics, London: Whitaker and Co., Vol. 5, Supplement 2.

McCance, R. and Widdowson, E. (1960), The composition of foods, London: HMSO, $3^{\text {rd }}$ edition. 
This article is (c) Emerald Group Publishing and permission has been granted for this version to appear here

(http://strathprints.strath.ac.uk/50435/). Emerald does not grant permission for this article to be further copied/distributed or hosted elsewhere without the express permission from Emerald Group Publishing Limited.

Meredith, D. and Oxley, D. (2014). Food and fodder: feeding England, 1700-1900.

Past and Present, 222, 163-214.

Mitchell, B.R. (1988), British historical statistics, Cambridge: Cambridge University Press.

Muldrew, C. (2011), Food, energy and the creation of industriousness: work and material culture in agrarian England, 1550-1780, Cambridge: Cambridge University Press.

Neild, W. (1842). Comparative statement of the income and expenditure of certain families of the working classes in Manchester and Dukinfield, in the years 1836 and 1841. Journal of the Statistical Society of London, 4 (4), 320-34.

Oddy, D. (1990). Food, drink and nutrition. in F.M.L. Thompson, ed., The Cambridge social history of Britain, 1750-1950. Volume 2. People and their environment (pp. 251 -78), Cambridge: Cambridge University Press.

Overton, M. (1996), Agricultural revolution in England: the transformation of the agrarian economy, 1500-1850, Cambridge: Cambridge University Press.

Overton, M. and Campbell, B. (1996). Production et productivité dans l'agriculture anglaise, 1086-1871. Histoire et Mésure, XI-3/4, 255-97.

Overton, M. and Campbell, B. (2006). Production and productivity in English agriculture, 1086-1871'. Retrieved from

http://www.helsinki.fi/iehc2006/papers3/Overton.pdf.

Parliamentary Papers (1 827), PP 1826-27 (550) v, 223, Third Report from the House of Commons Select Committee on Emigration to the United Kingdom.

Parliamentary Papers (1843), PP 1843 (177) liii, 69. Corn. Returns relating to the importation and exportation of corn, foreign and colonial. Statement of the quantities of each kind of grain and of malt imported into Great Britain from Ireland, in each year from 1800 to 1842.

Parliamentary Papers (1852), PP 1852 (538) li, 487. An account of all corn, grain, maize, meal and flour ... imported into the United Kingdom ... and a similar return ... of the imports from Ireland into Great Britain.

Parliamentary Papers (1854), PP $1854-55$ (1928) liii, 491, Agricultural Statistics (England), 1854. General Summary of Returns.

Parliamentary Papers (1863), PP 1863 (161) xxv, 1, Fifth Report of the Medical Officer of the Privy Council, with Appendix.

Parliamentary Papers (1864), PP 1864 (3416) xxviii, 1, Sixth Report of the Medical Officer of the Privy Council, with Appendix, 1863.

Parliamentary Papers (1871), PP 1871 C. 460 Ixix, 271, Agricultural Returns of Great Britain, with Abstract Returns for the United Kingdom, British Possessions and Foreign Countries.

Porter, G.R. (1851), The progress of the nation, in its various social and economical relations, from 1800 to the present time, London: Charles Knight and Co. 
This article is (c) Emerald Group Publishing and permission has been granted for this version to appear here

(http://strathprints.strath.ac.uk/50435/). Emerald does not grant permission for this article to be further copied/distributed or hosted elsewhere without the express permission from Emerald Group Publishing Limited.

Prince, H.C. (1989). The changing rural landscape, 1750-1850. In G.E. Mingay (Ed.),

The agrarian history of England and Wales. Vol. VI: 1750-1850 (pp. 7-83),

Cambridge: Cambridge University Press, 1989.

Razzell, P. (1994). The growth of population in eighteenth-century England: a critical reappraisal. In P. Razzell, Essays in English population history (pp. 173-206), London: Caliban.

Razzell, P. (1998). The conundrum of eighteenth-century English population growth. Social History of Medicine, 11 (3), 469-500. doi: 10.1093/shm/1 1.3.469

Salaman, R.N. (1949), The history and social influence of the potato, Cambridge: Cambridge University Press.

Schneider, E. (2013). Inescapable hunger? Energy cost accounting and the costs of digestion, pregnancy and lactation. European Review of Economic History, 17(3), 340-63. doi: 10.1093/ereh/het011

Sinclair, J. (1814), General report of the agricultural state and political circumstances of Scotland, Edinburgh: A. Constable \& Co., vol. 3.

Smith, J.H. (1955). The cattle trade of Aberdeenshire in the nineteenth century. Agricultural History Review, 3(2), 114-18.

Thirsk, J. (2002). Review of M.E. Turner, J.V. Beckett and B. Afton, Farm production in England 1700-1914. Economic History Review, 55(2), 355-6.

Thomas, B. (1982). Feeding England during the industrial revolution: a view from the Celtic fringe. Agricultural History, 56(1), 328-42.

Thomas, B. (1985a). Escaping from constraints: the industrial revolution in a Malthusian context. Journal of Interdisciplinary History, 15(4), 729-53.

Thomas, B. (1985b). Food supply in the United Kingdom during the industrial revolution. In J. Mokyr (Ed.), The economics of the industrial revolution (pp. 137-50), London: George Allen \& Unwin.

Thomas, B. (1993). Britain's food supply, 1760-1846: the Irish contribution. In B Thomas, The industrial revolution and the Atlantic economy: selected essays (pp. 81-99), London: Routledge.

Turner, M. (1981). Arable in England and Wales: estimates from the 1801 Crop Return. Journal of Historical Geography, 7(3), 291-302.

Turner, M.E., Beckett, J.V. and Afton, B. (2001), Farm production in England 1700 1914, Oxford: Oxford University Press.

Wrigley, E.A. and Schofield, R.S. (1981), The population history of England 1541 1871: a reconstruction, Cambridge: Cambridge University Press.

Young, A. (1771a), The farmer's tour through the east of England, Vol. ii, London: W. Strachan et al..

Young, A. (1771b), The farmer's tour through the east of England, Vol. iv, London: W. Strachan et al.. 